US Army Corps

of Engineers ${ }_{\circledast}$

Engineer Research and

Development Center

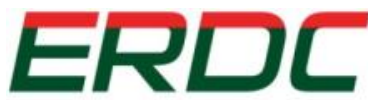

INNOVATIVE SOLUTIONS for a safer, better world

Center for the Advancement of Sustainability Innovations (CASI)

\title{
Sustainability-Related Publications Calendar Years 2015 - 2016
}

Franklin H. Holcomb, Patrick N. Deliman, and David B. Ringelberg

June 2017
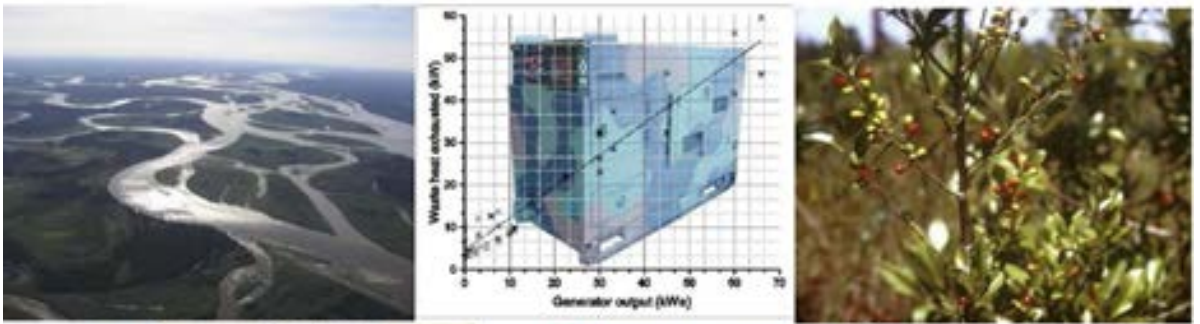

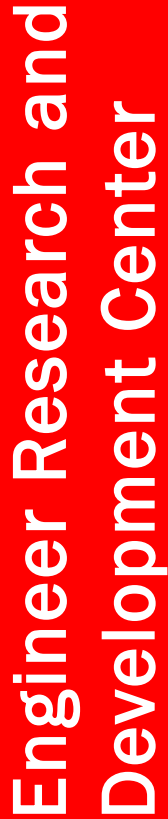
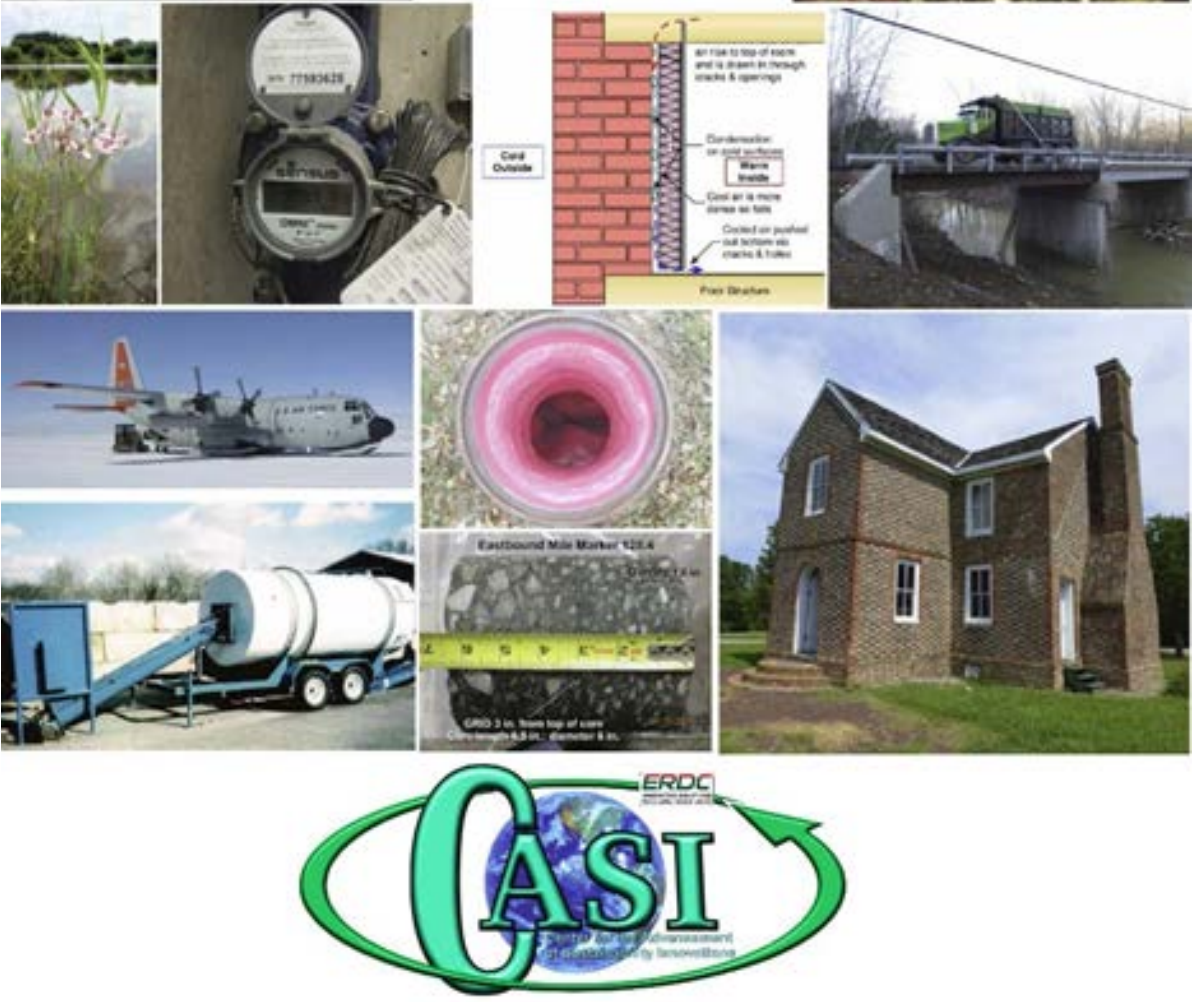

Approved for public release; distribution is unlimited. 
The U.S. Army Engineer Research and Development Center (ERDC) solves the nation's toughest engineering and environmental challenges. ERDC develops innovative solutions in civil and military engineering, geospatial sciences, water resources, and environmental sciences for the Army, the Department of Defense, civilian agencies, and our nation's public good. Find out more at www.erdc.usace.army.mil.

To search for other technical reports published by ERDC, visit the ERDC online library at http://acwc.sdp.sirsi.net/client/default. 


\section{Sustainability-Related Publications Calendar Years 2015 - 2016}

Franklin H. Holcomb

U.S. Army Engineer Research and Development Center (ERDC)

Construction Engineering Research Laboratory (CERL)

2902 Newmark Dr.

Champaign, IL 61824

Patrick N. Deliman

U.S. Army Engineer Research and Development Center (ERDC)

Environmental Laboratory (EL)

Waterways Experiment Station, 3909 Halls Ferry Road

Vicksburg, MS 39180-6199

David B. Ringelberg

U.S. Army Engineer Research and Development Center (ERDC)

Cold Regions Research and Engineering Laboratory (CRREL)

72 Lyme Road

Hanover, NH 03755-1290ress

Final Report

Approved for public release; distribution is unlimited.

Prepared for Center for the Advancement of Sustainability Innovations (CASI) 


\section{Abstract}

The Center for the Advancement of Sustainability Innovations (CASI) was established by the U.S. Army Engineer Research and Development Center (ERDC) as a new capability in 2006 hosted at the Construction Engineering Research Laboratory (CERL) in Champaign, IL. CASI was established with the goal of focusing the value of ERDC expertise, technologies, and partnerships toward helping the U.S. Army Corps of Engineers (USACE), the Army, and the Department of Defense (DoD) achieve more sustainable facilities and operations. CASI provides the military with capabilities that enhance national security by more effectively using limited resources and improving coordination and partnerships with host communities and stakeholders in the United States and around the globe. CASI teams strive to measure sustainability innovations against the Triple Bottom Line of mission, environment, and community. CASI focuses on cost savings, innovation, collaborative solutions, and continuous learning - which directly link sustainability to Army policy and guidance documents including Army Installations 2025; Installations, Energy and Environment Strategy 2025; Army Environment, Safety, \& Occupational Health Strategy 2025; and Energy Security and Sustainability $\left(E^{2}\right)$ Strategy. Note that this "summary of sustainability-related publications" incorporates descriptions of work related to the theme of sustainability conducted under many ERDC programs as well as CASI.

DISCLAIMER: The contents of this report are not to be used for advertising, publication, or promotional purposes. Citation of trade names does not constitute an official endorsement or approval of the use of such commercial products. All product names and trademarks cited are the property of their respective owners. The findings of this report are not to be construed as an official Department of the Army position unless so designated by other authorized documents. 


\section{Contents}

Abstract ii

Preface iv

1 Introduction 1

2 Anticipating Emerging Issues $\quad 6$

3 Climate-Driven Risks to Natural and Built Environments 12

4 Sustainable Installations - Net-Zero Planning 20

$5 \quad$ Sustainable Energy Solutions 23

6 Sustainable Water \& Waste Resources 33

7 Sustainable Facilities and Infrastructure 36

8 Sustainable Contingency Basing 68

9 Sustainable Natural Infrastructure $\quad 74$

10 Green Remediation and Reuse 84

$\begin{array}{ll}\text { Acronyms and Abbreviations } & 98\end{array}$

$\begin{array}{ll}\text { Included Documents } & 103\end{array}$

$\begin{array}{ll}\text { Report Documentation Page (SF 298) } & 107\end{array}$ 


\section{Preface}

This work was performed under the Center for the Advancement of Sustainability Innovations (CASI). CASI was established by the U.S. Army Engineer Research and Development Center (ERDC) as a new capability in 2006, hosted at the ERDC Construction Engineering Research Laboratory (CERL) in Champaign, IL. CASI's mission is to focus ERDC expertise, technologies and partnerships toward helping the U.S. Army Corps of Engineers (USACE), the Army, and the Department of Defense (DoD) achieve more sustainable missions, facilities, and operations. The technical monitor and Associate Director of CASI was Franklin H. Holcomb. Dr. Patrick Deliman of the ERDC Environmental Laboratory (EL) and David Ringelberg of the ERDC Cold Regions Research and Engineering Laboratory (CRREL) were Advisory Board members of CASI.

At the time of publication, Alan Anderson (CEERD-CZT) was the CERL Technical Director for Military Ranges and Lands and Dr. Patrick N. Deliman (CEERD-EVE) was the EL Technical Director for Environmental Modeling and Assessment. David B. Ringelberg is a Research Microbiologist and Associate Technical Director, Environmental Quality and Installations, Office of the Technical Director, CRREL (CEERD-RRN). The Deputy Director of ERDC-CERL was Dr. Kirankumar Topudurti and the Director was Dr. Ilker Adiguzel; the Deputy Director of ERDC-EL was Dr. J ack E. Davis and the Director was Dr. Beth C. Fleming; the Deputy Director of ERDC-CRREL was Dr. J oseph L. Corriveau and the Director was Dr. Lance D. Hansen.

COL Bryan S. Green was Commander of ERDC, and Dr. David W. Pittman was the Director. 


\section{Introduction}

\section{Background}

The Center for the Advancement of Sustainability Innovations (CASI) was established by the U.S. Army Engineer Research and Development Center (ERDC) as a new capability in 2006, hosted at the Construction Engineering Research Laboratory (CERL) in Champaign, IL. CASI's mission is to focus ERDC expertise, technologies and partnerships toward helping the U.S. Army Corps of Engineers (USACE), the Army, and the Department of Defense (DoD) achieve more sustainable missions, facilities, and operations. CASI provides the military with capabilities that enhance national security through more effective use of limited resources and improved coordination and partnerships with host communities and stakeholders in the United States and across the globe.

In all efforts, CASI teams strive to measure sustainability innovations against the Triple Bottom Line of mission, environment, and community. In addition, CASI focuses on cost savings, innovation, collaborative solutions, and continuous learning, all of which directly link sustainability to Army policy and guidance documents including Army Installations 2025; Installations, Energy and Environment Strategy 2025; Army Environment, Safety, \&Occupational Health Strategy 2025; and Energy Security and Sustainability (ES2) Strategy (https://www.army.mil/asaiee\#torg-resources).

This 2015-2016 Sustainability-Related Publications is the eighth annual CASI publication. Previous annual publications, published from 2008-15, are referenced below, with links provided to the documents (all of which are also located on the CASI website under the "Library" section).

Sustainability-Related Publications Calendar Years 2014 - 2015, Alan B. Anderson, Franklin H. Holcomb, Annette Stumpf, Elon Zeigler, Patrick N. Deliman, and Kevin Knuuti, ERDC/CERL TN-16-2, March 2016, http://acwc.sdp.sirsi.net/client/search/asset/1049647

CASI Work Plan Calendar Year 2014, Alan Anderson, Franklin Holcomb, Annette Stumpf, and Elon Zeigler, ERDC/ CERL TN-14-1, J une 2014, http://acwc.sdp.sirsi.net/client/en_U.S./search/asset/1036586

CASI Work Plan Calendar Year 2013, William D. Goran, Michelle Hanson, Elon Zeigler, and Annette Stumpf, ERDC/ CERL TN-13-1, February 2013, ERDC/ CERL TN-13-1 http://acwc.sdp.sirsi.net/client/search/asset/1025640 https://eko.usace.army.mil/_secure/4BEEA029-E2E0-0960748272F8F7EF/ERDC-CERL_TN13-1.pdf 
CASI Work Plan Calendar Year 2012, William D. Goran, Michelle Hanson, Elon Zeigler, and Annette Stumpf, ERDC/ CERL TN-12-1, J anuary 2012, https://eko.usace.army.mil/_secure/4BDCC685-B81D-1CD13D958CFDE2DB11C5/2012WorkPlan-13-Jan-FINAL-smallfile.pdf

Center for Advancement of Sustainability Innovations: 2011 Work Plan, William Goran, et al., ERDC/ CERL TN-11-11, J anuary 2011, https://eko.usace.army.mil/centers/casi/library/?syspage=Documents\&id=263037

Center for Advancement of Sustainability Innovations: 2010 Work Plan, William Goran, et al., ERDC/CERL TN-10-1, April 2010, at either: https://eko.usace.army.mil/_secure/4B7DD77A-C376-36A8A84FEC6F7A1DC3BE/FY_2010_CASI_Work_Plan.pdf https://eko.usace.army.mil/centers/casi/library/?syspage=Documents\&id=263155

CASI Work Plan Fiscal Year 2009, William Goran, Annette Stumpf, and Michelle Hanson, ERDC/CERL Special Report 08-21, November 2008, https://eko.usace.army.mil/_secure/4BA5065B-E946-50E120324297E3099A62/Work_PlanFINALMay1509_\%282\%29.pdf

Fiscal Year 2007 Annual Report, Center for the Advancement of Sustainability Innovations, William Goran, ERDC/CERL Technical Note (TN-08-02), May 2008, (CASI Work Plan for 2008), http://acwc.sdp.sirsi.net/client/search/asset/1002025

\section{Objective}

The purpose of this series of summary documents has been to:

- Provide a framework to capture diverse sustainability activities being conducted by ERDC

- Help various sponsors, partners and stakeholders understand the scope of sustainability activities and expertise that ERDC can offer

- Identify areas where activities can be leveraged for those with similar interests or ongoing investments

- Suggest potential research areas that have been conceived but not yet resourced by potential partners and sponsors

- Enhance dialog and teaming across the different technical focus areas

- Document ERDC sustainability activities

Of special note is the inclusive nature of this "summary of sustainabilityrelated publications," which incorporates descriptions of work related to the theme of sustainability that was conducted under many ERDC programs as well as CASI. 


\section{Approach}

\section{Technology Focus Areas}

One of the key values of CASI is to provide "systems level" expertise to address complex sustainability issues. Installations and communities engage across a wide range of economic, environmental, social, and mission issues that interact in multiple temporal and spatial dimensions. Most of the issues addressed in this document span multiple technology focus areas. The focus areas are simply useful "bins" for planning suites of projects and joining groups of experts. These technology focus areas also indicate the explicit topical areas where CASI has selected teams of experts from within and beyond ERDC. As the sustainability challenges of the U.S. military change, these technology focus areas will also change. Currently, the nine CASI technology focus areas are:

- Anticipating Emerging Issues

- Climate-Driven Risks to Natural and Built Environments

- Sustainable Installations - Net Zero Planning

- Sustainable Energy Solutions

- Sustainable Water \& Waste Resources

- Sustainable Facilities and Infrastructure

- Sustainable Contingency Basing

- Sustainable Natural Infrastructure

- Green Remediation and Reuse.

\section{Coordination and Outreach}

\section{Website}

The CASI website is supported by the Engineering Knowledge Online $\left(\mathrm{EKO}^{\circledR}\right)$ portal: https://eko.usace.army.mil/centers/casi/

The website includes a calendar of events, information on each of the technology focus areas, a library with all available CASI documents and publications, and links to other related sites. Several CASI technology focus areas manage additional web resources supplementing the information on CASI's website, with links from the CASI website. 


\section{Marketing Materials}

The CASI brochure and poster are available for download on the CASI website. A CASI display supports marketing activities at conferences, job fairs, and other venues.

\section{Electronic Copies}

Electronic copies of the CASI annual publications are available at: https://eko.usace.army.mil/centers/casi/library//

\section{Partnerships}

CASI strives to bring the best team to any specific challenge and this often involves the creation of unique partnerships for each project. CASI has formal and informal partnership arrangements with many academic, industry, and government organizations. Many of the descriptions of these sustainability-related publications highlight these partner organizations.

\section{Projects Represented in This Publications Summary}

The summary is an important tool for CASI to share information and create dialog across multiple stakeholders and organizations. While CASI/Sustainability projects are usually funded by individual sponsors, most projects are also of interest to other sponsors. This summary allows for all sponsors to learn about and follow the progress of any project or area of interest, and where appropriate, to acquire access to project outcomes. In addition, a project sponsored by one organization may help create the dialog necessary to initiate a related or follow-on effort tailored to another organization.

This summary focuses on completed projects. Projects discussed in this report were finished during calendar years 2015-16. While each project is identified within a specific technology focus area, many of these projects are relevant across multiple technology focus areas. The immediate outcomes could be a service (e.g., a new web capability), a forum (e.g., the Interagency Climate Change Impacts and Adaptations forum sessions), a demonstration of a capability, and/or a publication. However, for many CASI/ Sustainability initiatives, long-term outcomes are improved understanding of system relationships and tradeoffs, and/ or the identification of new pathways to achieve more efficient and sustainable military operations. 


\section{CASI Leadership}
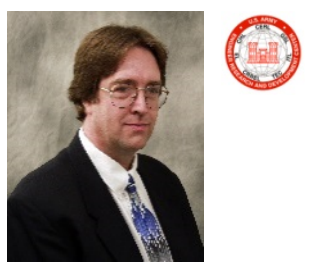

\section{Alan B. Anderson CASI Director 217-373-7233 Alan.B.Anderson@usace.army.mil}
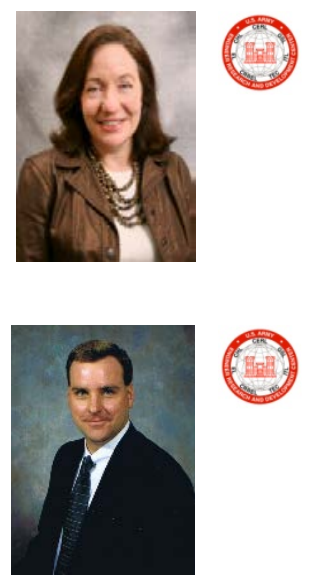

Annette Stumpf Installation Outreach 217-373-4492

Annette.L.Stumpf@usace.army.mil

Patrick N. Deliman CASI Advisory Board 601-634-3623

Patrick.N.Deliman@usace.army.mil
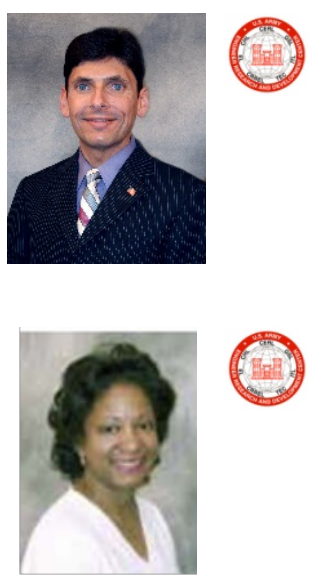

Franklin H. Holcomb CASI Associate Director 217-373-5864

Franklin.H.Holcomb@usace.army.mil

Elon Zeigler Knowledge Management Representative

217-373-7256

Elon.P.Zeigler@usace.army.mil

David B. Ringelberg CASI Advisory Board (603) 646-4744 David.B.Ringelberg@usace.army.mil 


\section{Anticipating Emerging Issues}

This focus area strives to achieve a threefold purpose, to: (1) engage stakeholders through forums, white papers, publications and other means about emerging issues of concern, (2) interpret how these emerging issues might impact defense activities and operations, and (3) initiate a dialog about potential courses of action to respond to these issues. The CASI White Paper series is one forum that accomplishes this purpose.

Giselle Rodriguez, Dominique Gilbert, LTC M. Zillur Rahman, Jorge Flores, Peter Stynoski, Cate Fox-Lent, and Igor Linkov. ERDC SR-17-1. Material Life Cycle Analysis for the Reduction of Waste Generation at Military Installations, http://dx.doi.org/10.21079/11681/22601

In 2011, the U.S. Army implemented the Net Zero Initiative, which includes Net Zero Energy, Net Zero Water and Net Zero Waste (NZW). A NZW installation is an installation that reduces, reuses, and recovers waste streams by converting them to resource value without using a landfill. To assist in that effort, this work reviewed the policies and initiatives aimed at reduction waste generation, discussed the challenges on the implementation of improvement efforts, and outlined existing research and operational needs to support more efficient operations and the achievement of Net Zero goals.

MacAllister, Irene E., Jinelle H. Sperry, and Pamela Bailey. ERDC TN-16-1. Identification of Insect-Plant Pollination Networks for a Midwest Installation: Fort McCoy, WI, http://acwc.sdp.sirsi.net/client/en_US/search/asset/1049246

Pollinating insects and pollinator dependent plants are critical components of functioning ecosystems, yet for many DoD installations, the identities and relationships between pollinators and plants are unknown. This study demonstrated methods for compiling and analyzing readily available information for insect pollinators and pollination dependent plants for a single installation, Fort McCoy, WI. Although installation documents identified a total of 1470 insect species and 972 plant species were identified on the installation, this work focused on species of conservation concern (nine pollinator insect species and three pollinator-associated plant species). Published information on insect pollinators and pollination dependent plants was then used to conduct a basic plant-pollinator network analyses using free analytical network software (software package R), which revealed that all the plant species of conservation concern are pollinated 
by several insect pollinator species. However, many pollinator insect species of conservation concern were associated with a limited number of host plant species. The results of this work suggest that analyses that rely on publicly available information provide a useful starting point in determining basic, binary plant-pollinator relationships. Field-collected data, e.g., frequency of pollinator-plant interactions, would be required for a more detailed, robust network analysis. Results of the insect pollinators bipartite mutualistic network analysis. Pollinators are indicated with brown boxes and plants species are in green.

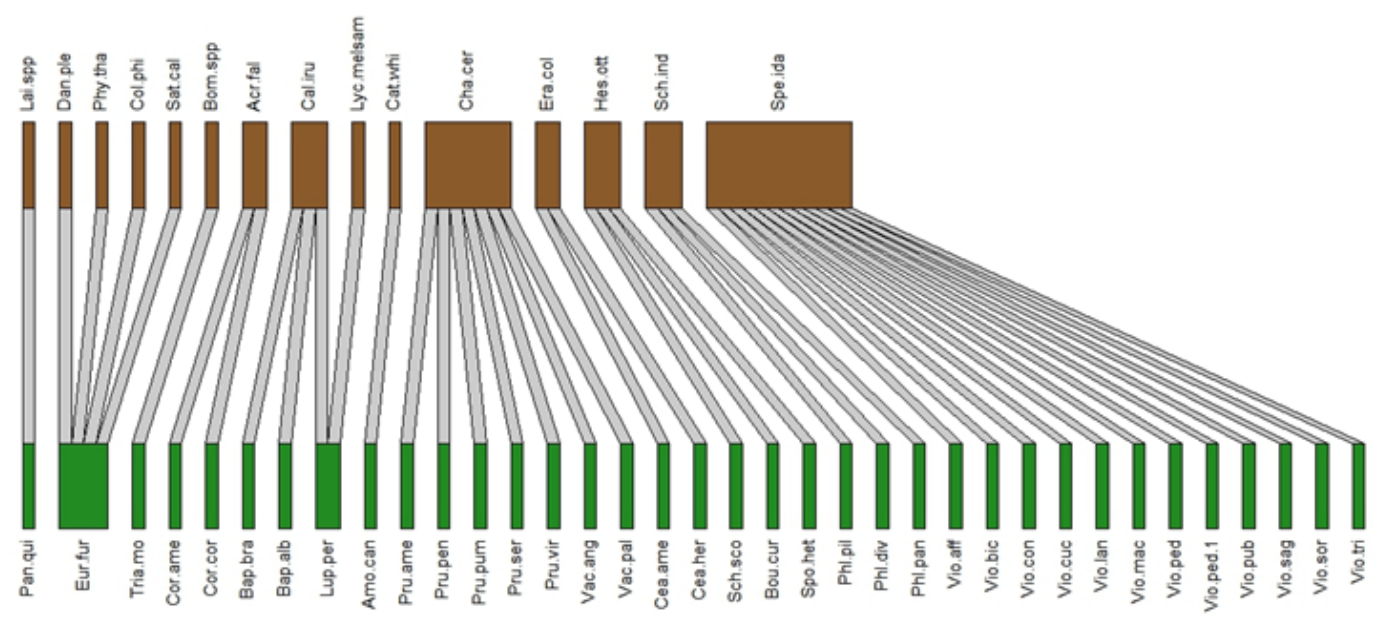

Ping Gong. Draft ERDC/EL TR. Clustered Regularly Interspaced Short Palindromic Repeat/CRISPR-associated protein 9 (CRISPR/Cas9)-based Gene Drives for Invasive Species Management on Military Lands.

Invasive species are increasingly recognized as serious social, economic, and ecological problems. Applications of genetic engineering-based technologies to the control of invasive species are emerging as an important area of innovation in this regard. Recently, gene drive (i.e., a mechanism to spread the desired genes and associated traits into the target population) has emerged as a promising genetic biocontrol strategy to combat invasive species like carp and mosquitos. Unlike existing technologies based on homing endonucleases, zinc finger nucleases, and transcription activator-like effector nucleases, which depend on the cumbersome custommaking of new proteins for each deoxyribonucleic acid (DNA) target, the CRISPR system uses ribonucleic acid (RNA) as its DNA-homing mechanism, which makes it low cost, high efficiency, and easy to implement, and which also dramatically shortens the design-build-test cycle for gene drive development. 


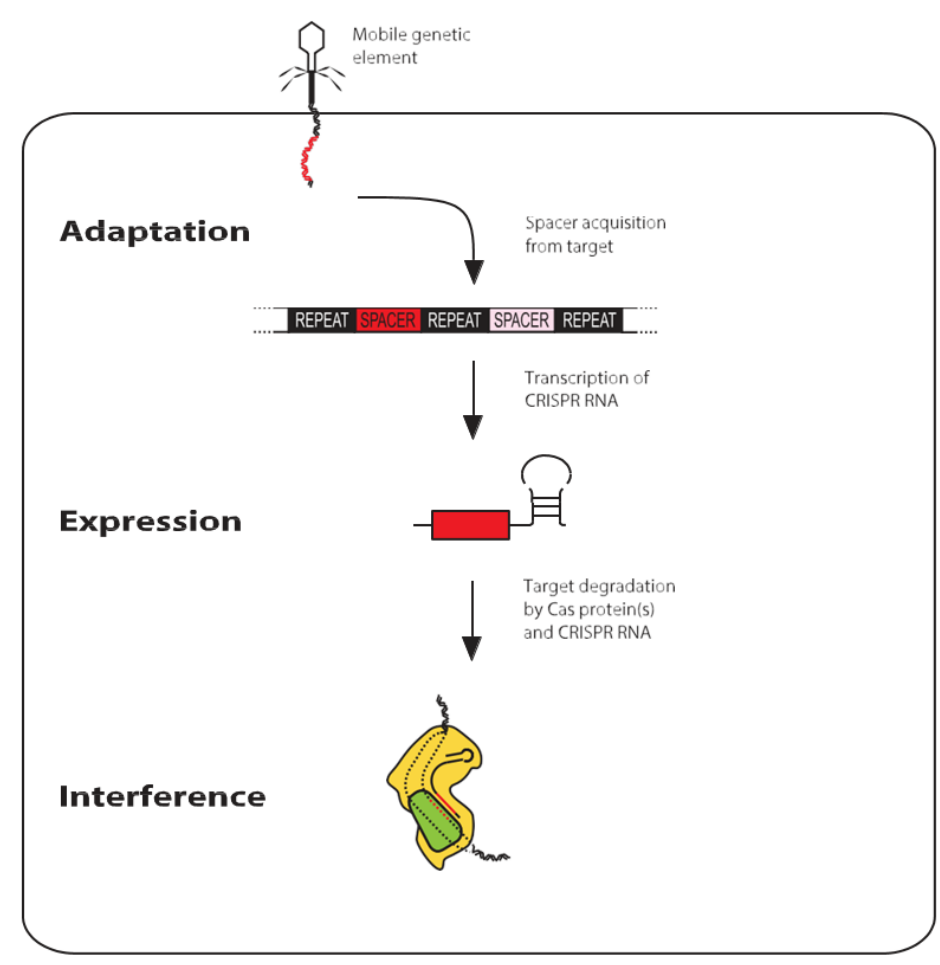

The key steps of CRISPR-Cas immunity.

While relying on exactly the same copying/ homing mechanism as naturally existing homing endonucleases, CRISPR/ Cas9-mediated gene drives can sweep a "deleterious" gene through a population exponentially faster than normal Mendelian inheritance, thus suppressing or eradicating the target invasive species. CRISPR/ Cas9-based gene drives are poised to become a self-sustaining, highly efficient, environmentally benign, and cost effective alternative for invasive species control. Biosafety, ecological risks, regulations, public perceptions, and limitations surrounding the development and release of CRISPR/ Cas9-based gene drives are also discussed.

Dawn A. Morrison, Colin D. Wood, Timothy K. Perkins, et al. 2016. ERDC/CERL SR-16-3. Extreme Environment Basing: Contingency Basing in Dense Urban and Megacity Environments, https://erdc-library.erdc.dren.mil/xmlui/bitstream/handle/11681/21471/ERDC-CERL\%20SR-163\%20Dist\%20A.pdf? sequence=1\&isAllowed=y

The U.S. military may be required to operate in dense urban and megacity environments, which may pose significant challenges for contingency basing. This work reviews and analyzes the potential disconnect between existing doctrine, standard operating procedures, and the human geographic reality of dense urban environments and megacities as concerns contingency basing. The work: (1) characterizes 41 projected megacities using the Army Chief of Staff's Strategic Study Group's megacity typology, (2) performs 
crosswalk analysis between this characterization and existing contingency basing doctrine, (3) details doctrinal gaps, specifically those pertaining to site selection, logistics, and security, and (4) recommends future research to alleviate those gaps.

Dense urban environments, top-left, clockwise: favelas of Rio de Janeiro; traffic in Dhaka, Bangladesh; residential area of downtown Hong Kong; Slums surrounding the Mumbai International Airport.

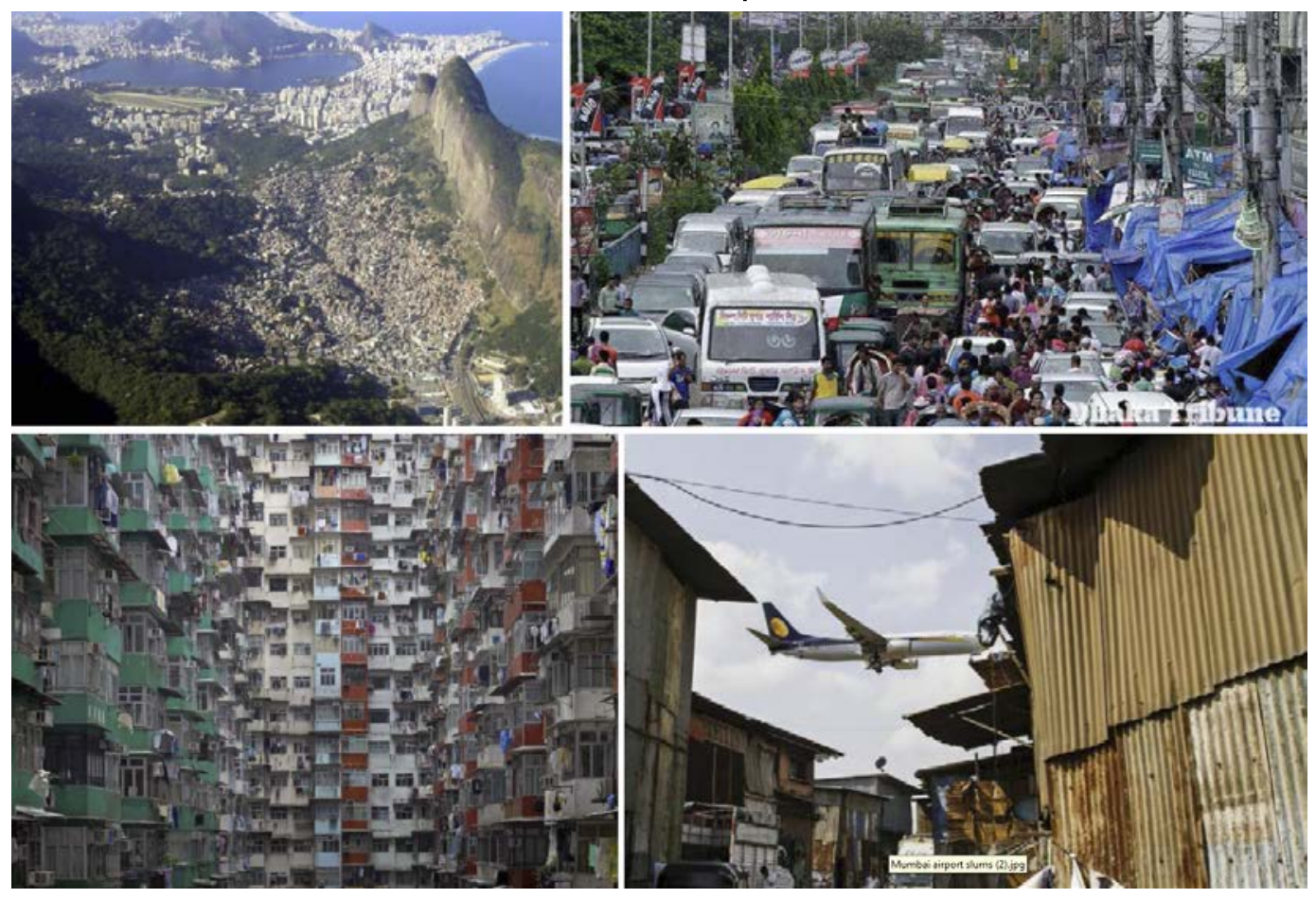

David Delaney, Patrick Guertin, Michael White, et al. 2016. ERDC-CERL TN-16-1. Assessment of Small Arms Munitions Impacts on Natural Infrastructure in Sensitive Downrange Areas on Military Installations, http://acwc.sdp.sirsi.net/client/en_US/search/asset/1048789

Large areas of high quality terrestrial natural infrastructure exist downrange of small arms training ranges on DoD installations. Live-fire training has caused concern to regulatory entities due to the potential impacts on natural resources, and to safety concerns expressed by adjoining land owners. This paper investigated whether there are reliable documented methods to quantify the number of bullets that escape the cantonment berm and ultimately fall down range via queries among Natural Resource peers and a technology review to document existing methods that address bullet fate on ranges. 
Responses to the inquiries indicate that Natural Resource personnel on military facilities or other state or Federal agencies do not have adequate tools or guidance to address the potential issue of smalls arms munition impacts within sensitive downrange areas. It was recommended that military installations further examine acoustical techniques for quantifying bullet overshot and ricochets into sensitive wildlife areas. Acoustical techniques offer a viable method for quantifying bullet intrusions into downrange areas. However, a more comprehensive testing procedure must be tested to gauge the effectiveness of this technique at bermed and unbermed ranges under different field conditions.

Victor F. Medina. Richard J. Scholze, Scott A. Waisner, et al. ERDC SR-15-2, Energy and Resource Recovery from Wastewater Treatment: State of the Art and Potential Application for the Army and the DoD, http://acwc.sdp.sirsinet/client/en_US/search/asset/1043946

This report summarizes a study to assess energy and resource recovery from wastewater treatment and assess short- and long-term opportunities and impacts for the Army and DoD in general. The organic material in wastewater contains inherent energy. The challenge is concentrating and recovering this energy. Several methods are available; of these, anaerobic digestion (either of the sludge, or directly applied to the wastewater using an Upflow Anaerobic Sludge Blanket or a similar reactor) is the most advanced and can be readily applied to existing military installations or to contingency operations. Recovery of chemical products is another option for wastewater treatment. 
Laboratory and pilot reactors used to study anaerobic digestion for treating Forward Operating Base wastes.

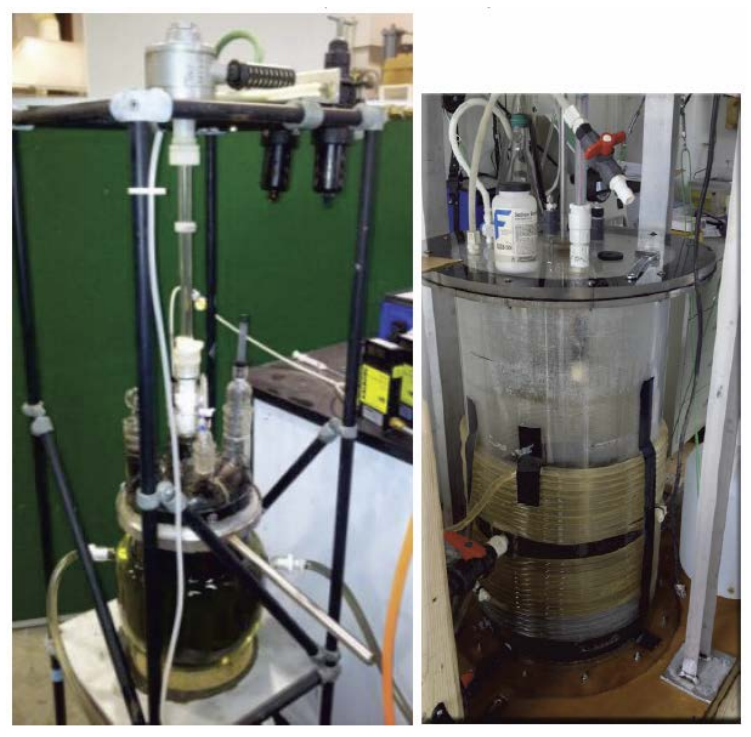

The most commonly recovered products are nutrients, in the form of nitrogen $(\mathrm{N})$ and phosphorus $(\mathrm{P})$. The simplest way is to recycle the collected and digested biosolids (sludges), either for direct soil application or by incorporation into compost. Resource recovery from wastewater may eventually include biopolymers that could make bioplastics or valuable nanometals that are increasingly found in consumer products. Many of the energy recovery technologies and most of the resource recovery approaches (beyond simple bi-

osolids recovery) require large scale operations to be economically viable at this time. Wastewater treatment facilities that serve Army and other DoD installations tend to be relatively small, limiting the application of many approaches that might be practicable in the civilian sector. ERDC should focus research on technologies that could be economically applied to smaller treatment plants on the order of 3 to $10 \mathrm{mgd}$. 


\section{Climate-Driven Risks to Natural and Built Environments}

Climate change is one future trend that will impact our national security. Rising global temperatures, changing precipitation patterns, climbing sea levels, and more extreme weather events will intensify the challenges of global instability, hunger, poverty, and conflict. Climate change is seen as a "threat multiplier" because it has the potential to exacerbate many of the challenges facing the Nation today - from infectious disease to terrorism. A changing climate will have real impacts on our military and on the way it executes its missions, on the way it is called upon to support civil authorities and to provide humanitarian assistance and disaster relief in the face of more frequent and more intense natural disasters.

This focus area addresses the challenges of changing climatic and related conditions. Challenges include those associated with facilities, lands, and operations, and the stressors, posed by changing climatic conditions, on regional and national stability across the globe. Activities in this focus area involve several partnerships with other agencies and nations.

\section{Wade Wall. 2016. ERDC TR-16-1. Effects of Climate Change and Urban Development on Army Training Capabilities: Firing Ranges and Maneuver Areas, http://acwc.sdp.sirsi.net/client/en_US/search/asset/1054587}

Army stationing analyses have historically been conducted under the assumption that most conditions at and around installations will generally remain static. Previous optimal stationing analyses have resulted in substantial costs associated with moving units, constructing buildings and roads, and local investments in the development of off-post housing, shopping facilities, eating, and other businesses that provide quality of life for soldiers and their families. In reality, the capacity of the natural, social, and built infrastructure changes over time,

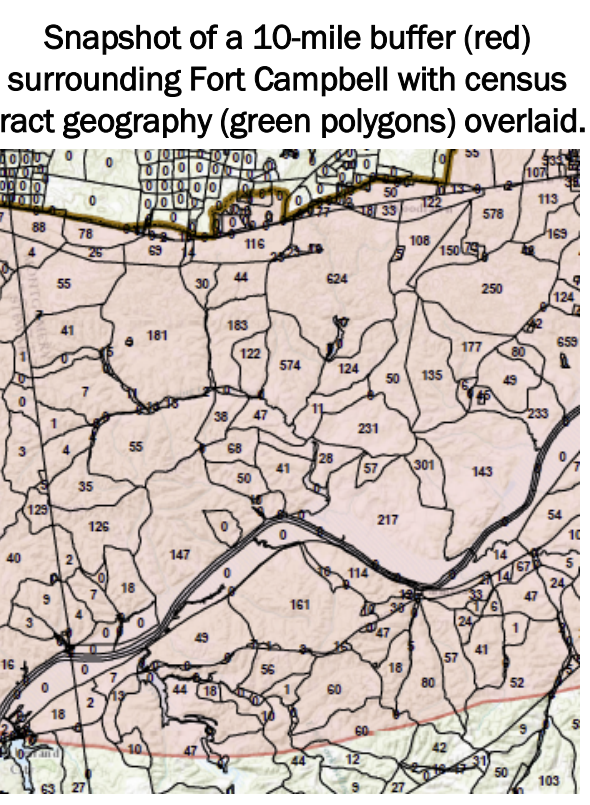
and, this non-stationarity should be considered in stationing analyses to: 
(1) avoid premature abandonment of expensive buildings and associated infrastructure, and (2) avoid costly realignments to locations where capacity is being adversely affected by change. This work documents efforts completed in Fiscal Year 2014 (FY14) that began to investigate how potential changes associated with climate and urban development might affect the ability of Army installations to continue to conduct training on firing ranges and in maneuver areas.

Michelle Swearingen. 2016. ERDC/CERL TR-16-29. Effects of Climate Change, Urban Development, and Threatened and Endangered Species Management on Army Training Capabilities: Firing Ranges, http://acwc.sdp.sirsi.net/client/en_US/search/asset/1054587

Army stationing analyses have historically been conducted under the assumption that conditions at and around installations will remain static. In reality, the natural, social, and built infrastructure changes over time, and this non-stationarity should be considered in stationing analyses to ensure continuation of each installation's mission. This work documents efforts completed in FY15 that addressed the temporal aspects of population growth and its potential for negatively impacting an installation's training areas, and the potential impact of currently listed and species at risk of being listed to the endangered species list. A modified method for estimating population impact and a new method for estimating the impact of listed and at-risk species are described.

Juliana M. Wilhoit, Grace M. Díaz-Estrada, James P. Miller, et al. 2016. ERDC/CERL;TR-16-32. Water Stress Projection Modeling, http://hdl.handle.net/11681/20661
U.S. Army sta- tioning is a con- stant multiscale process. Large scale stationing, which is identi- fied with strate- gic realign-

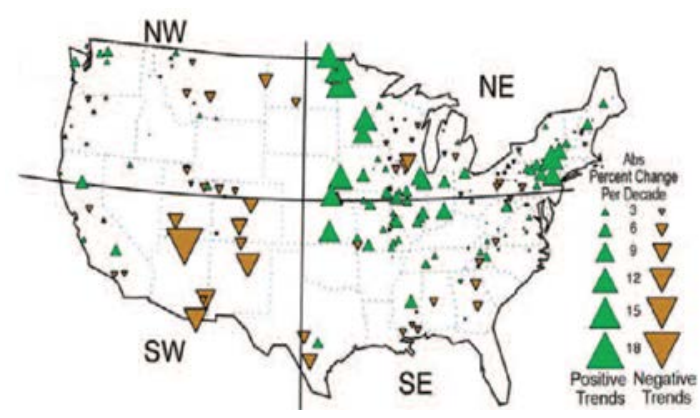
Magnitude of annual floods from the 1920s to 2008 shown with magnitude (size) and direction (color).

ments, requires some level of modeling to determine whether the movement of tactical equipment and large numbers of personnel is both economical and continues to meet future long-term strategic requirements. This work explored how climate change implications on water resources may affect military installations in the future, and used that information to outline 
WASP model, which serves as a decision support system tool that integrates water stressors resulting from global climate change and regional growth to assess the availability of water to an installation in the future. WASP is a tool that provides a scalable solution to incorporate water into the U.S. Army stationing process and to generate a maximum number of personnel at an installation, which can be used as an Optimal Stationing of Army Forces (OSAF) constraint. To test the impact of climate change on the U.S. Army, the model was applied to five case study installations located across the continental United States in a variety of climate zones.

James Miller, Juliana Wilhoit, Kristina Tranel, et al. ERDC/CERL TR-15-24. Integrated Climate Assessment for Army Enterprise Planning, http://acwc.sdp.sirsi.net/client/en_US/search/asset/1045989

In the decades to come, climate change is expected to impact the Army's costs, its abilities to train and maintain the force, and its mission capabilities. These potential climate change impacts need to be considered in the Army's stationing/ restationing analysis process to ensure that future decisions concerning locating and relocating Army Forces are optimized to miniImpact on low and high voltage transmission lines. mize costs while maintaining the ability to effectively train, maintain, and deploy forces. This study was performed to identify and recommend possible improvements to the Army's stationing/ restationing analysis process, specifically, by including climate factors in the stationing analysis process to enable a more complete modeling and cost analysis.

John W. Weatherly and Mattson A. Rosenbaum. Draft ERDC/CRREL TR. Use of Heat- and Fire-Risk Indices to Project Local Climate Impacts on Selected Army Installations.

Climate change is expected to produce increasing impacts on training and infrastructure on Army installations in the coming decades. Planning to enable Army installations to adapt to the changing climate can be supported by suitable estimates of climate impacts over timeframes suitable for strategic plans. This work computed the impacts of future climate 
change on available training days for seven sample Army installations using projections of temperature and precipitation from global climate models. The number of days with heat-related training restrictions and fire risk from live-fire training were calculated using observed weather station data and climate model projections for several future climate scenarios. For these installations, increased temperatures in time periods centered on 2030, 2050, and 2090 result in a greater number of days with heat categories above 84 and $90^{\circ} \mathrm{F}\left(28.9\right.$ and $\left.32.2^{\circ} \mathrm{C}\right)$ and with high fire risk. The climate impact on heat-affected training days is greater in the U.S. Southeast, where high humidity also contributes most to the heat index. The impact on the fire risk for training is greater in the U.S. Southwest, where the low precipitation and high temperatures contribute to the high drought index. Future work will include additional installations and climate variables.

Michelle E. Swearingen, Andrew Fulton, Wade Wall, et al. 2016. ERDC TR-16-1. Effects of Climate Change and Urban Development on Army Training Capabilities: Firing Ranges and Maneuver Areas, http://hdl.handle.net/11681/20656

Army stationing analTen-mile buffer with census tracts overlaid. yses have historically been conducted under the assumption that most conditions at and around installations will generally remain static. Previous optimal stationing analyses have resulted in substantial costs associated with moving units, constructing buildings and roads, and local investments in the devel-

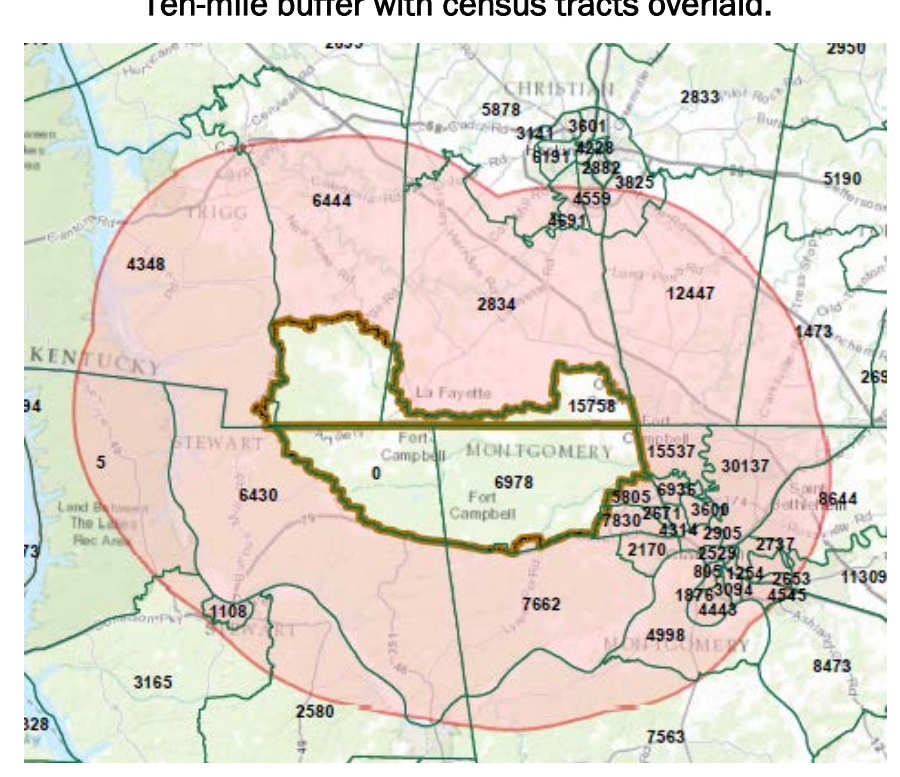
opment of off-post housing, shopping facilities, eating, and other businesses that provide quality of life for soldiers and their families. In reality, the capacity of the natural, social, and built infrastructure changes over time, and this non-stationarity should be considered in stationing analyses to: (1) avoid premature abandonment of expensive buildings and associated infrastructure, and (2) avoid costly realignments to locations where 
capacity is being adversely affected by change. This report documents efforts completed in FY14 that began to investigate how potential changes associated with climate and urban development might affect the ability of Army installations to continue to conduct training on firing ranges and in maneuver areas.

Juliana Wilhoit, Scott Tweddale, Matt Hohmann, et al. ERDC/CERL TR-16-29. Effects of Climate Change, Urban Development, and Threatened and Endangered Species Management on Army Training Capabilities, http://hdl.handle.net/11681/20653

Army stationing analyses have historically been conducted under the assumption that conditions at and around installations will remain static. In reality, the natural, social, and built infrastructure changes over time, and this nonstationarity should be considered in stationing analyses to ensure continuation of each installation's mission. This work documents efforts completed in FY 15 that addressed the temporal aspects of population growth and its potential for negatively impacting an installation's training areas, and the potential impact of currently listed and species at risk of being listed to the endangered species list. A modified method for estimating population impact and a new method for estimating the impact of listed and at-risk species are described.
Map of urban development in relation to distance from ranges at Fort A.P. Hill.

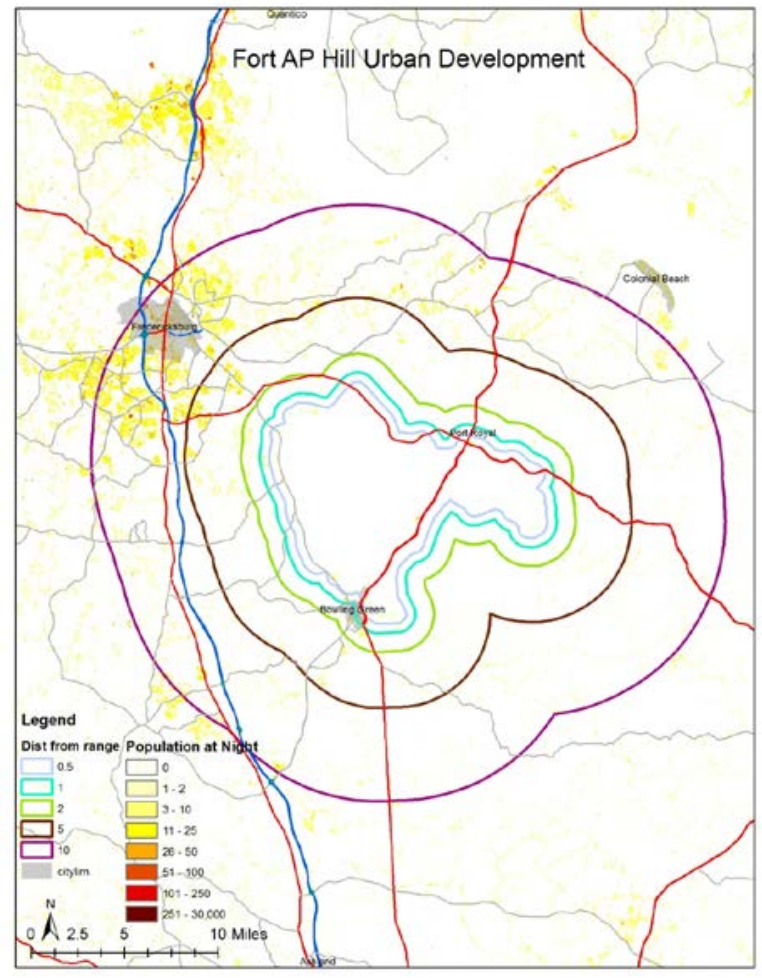


Robert C. Lozar and James D. Westervelt. ERDC/CERL TR-15-2. Multivariate Bioclimatic Ecosytem Change Approaches,

http://acwc.sdp.sirsi.net/client/en_US/search/asset/1042066

Changes in climatic parameters are important in that they affect the military's ability to perform its national defense mission and to manage military lands. The military must have the ability to predict climatic changes on specific installations. To support this need, this research Bio12 annual precipitation exhibits the Benning "climatic tested and evaluated the application of six multivariate approach techniques to predict climatic changes on a specific Army installation, Fort Benning, GA. The six approaches were tested for their ability to identify where anticipated future conditions might be found hole." The darker blue represents locally lower precipitation.

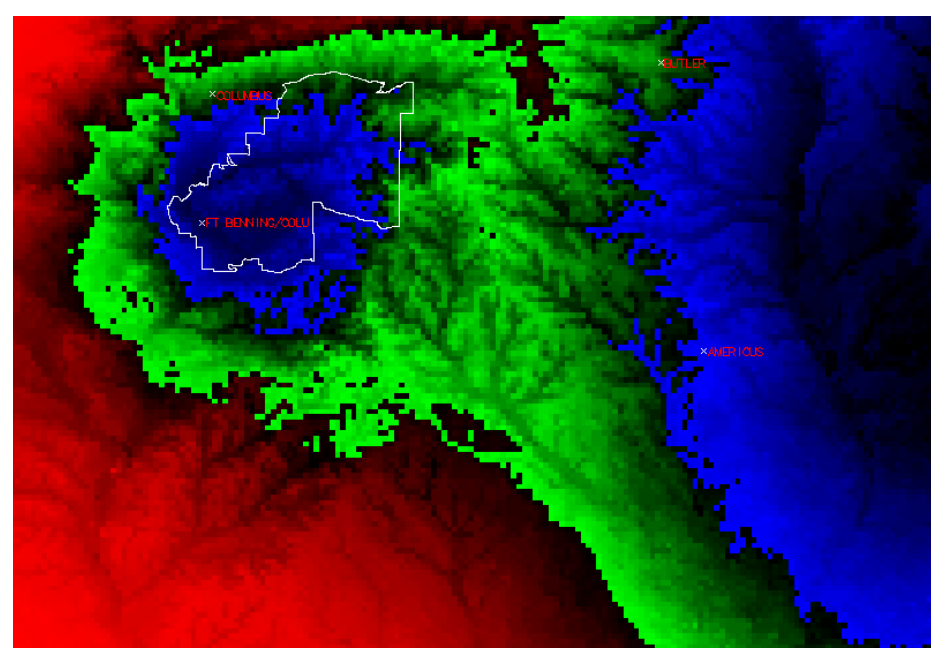
today using a set of 19 bioclimatic parameters derived from climate change data. The evaluation found that the Primarily Analogous Multivariate approach developed during this research clearly distinguished itself from the other five approaches in that it successfully determined future climatic factors at the installation, as well as at the sub-installation level using the currently available climatic data.

Janet P. Hardy. 2015. ERDC/CRREL SR-15-1. Indicators of Physical and Biological Trends around the McMurdo Station: A Literature Review, http://acwc.sdp.sirsi.net/client/search/asset/1043447

The U.S. Antarctic Program (USAP) is managed by the National Science Foundation, Division of Polar Programs (NSF-PLR), which has the responsibility for all logistics and operations related to U.S. scientific research in Antarctica and aboard ships in the Southern Ocean. For years, scientific literature has focused on global environmental change and, in particular, on the accelerated change occurring, and predicted to occur, in the Polar Regions. 
This report summarizes documented changes that have occurred in Antarctica, with a focus on the Ross Sea region, as well as projections of environmental change expected to occur in the next 100 years. Many of the observed changes in the Ross Sea region since 1960, such as increased air and soil temperature, decreased glacial extent, and sea level rise, are consistent with a warming climate; however, the observed increase in sea-ice extent does not fit an expected pattern and is explained by a shift in circumpolar circulation. Models predict the observed changes to continue over the next 100 years, except that they anticipate the sea-ice extent in the Ross Sea region to decrease significantly. This report also presents potential implications of these changes for USAP operations and logistics, primarily in response to the reduced seaice extent and higher air and soil temperatures.

James D. Westervelt and Grace M. Díaz-Estrada. ERDC/CERL SR-16-1. BlackSwan Event Assessment for Fort Leonard Wood, Missouri, http://acwc.sdp.sirsi.net/client/en_US/search/asset/1049146

Emergency preparation typically involves evaluating disaster potential and consequences, followed by disaster preparedness. Potentials are informed by history, with the easy human belief that one must obviously prepare for the past. However, a class of disasters involve events that may not have been anticipated, but in hindsight appear to be obviously overlooked. This report attempts to identify such "black-swan" events, i.e., potential disasters in the Fort Leonard Wood area that might well attract more attention in future planning exercises. 
Michael R. Kemme. ERDC/CERL TR-15-30. Developing Baselines for Prescribed Burning Smoke Management Plans and Best Management Practices, http://acwc.sdp.sirsi.net/client/en_U.S./search/asset/1047387

Prescribed fire is a critical component of Army wildland fire management and prevention, range maintenance, and ecosystem management. The U.S. Environmental Protection Agency (USEPA) sets policy on controlling emissions from prescribed burning that is complex and still evolving. States have implemented USEPA regulations and policy by developing their own regulations, Smoke Management Programs (SMPs), and State Implementation Plan conditions. A wide array of guidance for developing SMPs is available, along with tools for managing prescribed fire emissions. The information in this report and many of the tools described here are applicable to Army installation management of prescribed burn smoke emissions. The Army already has the basic framework for developing SMPs within the installationlevel Integrated Wildland Fire Management Plan that requires information on smoke management. However, this work discusses and recommends an approach for developing complete Army SMPs that align with the required elements of state/ tribal SMPs. It is also recommended that a great deal of flexibility be allowed in the installation-level SMP to account for variation in an installation's need to control smoke emissions and to meet state regulatory requirements.

Failure to manage the Army's necessary prescribed burn programs could result in a variety of impacts that could directly affect vital training missions.

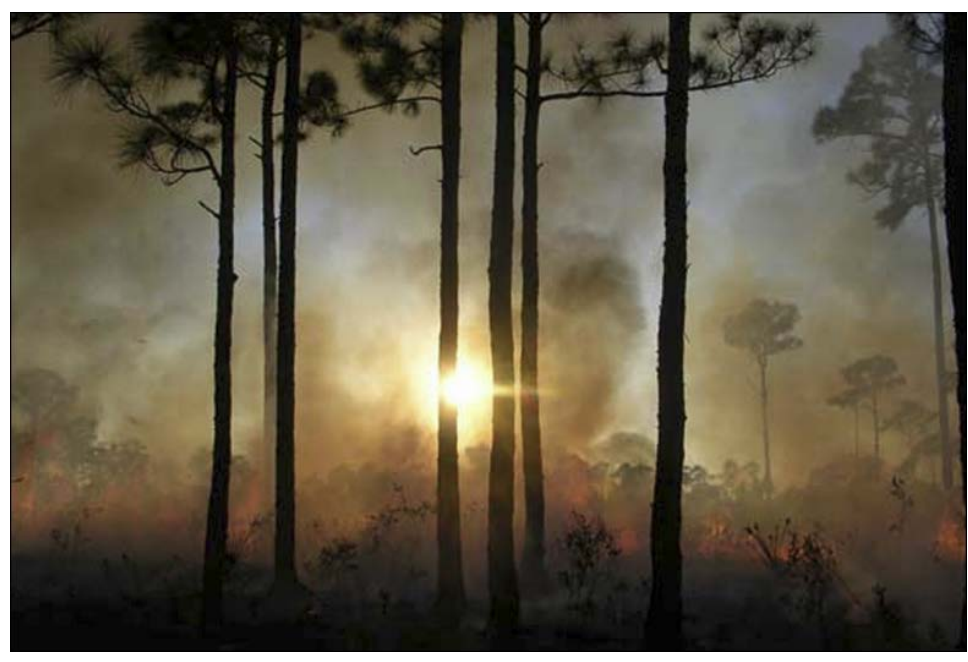




\section{Sustainable Installations - Net-Zero Planning}

Net Zero is a strategy that strives to bring the overall consumption of resources on installations down to an effective rate of zero. The Army's vision is to appropriately manage our natural resources with a goal of achieving Net Zero Installations. Today, the Army faces significant threats to our energy and water supply requirements both at home and abroad. Addressing energy security and sustainability is operationally necessary, financially prudent, and mission essential. The Net Zero concept encompasses not only energy, but water and waste as well. The Army is investing in its installations to improve efficiencies in energy, water and waste for the benefit of the current and future force, and of the Nation.

Elisabeth Jenicek. 2016. ERDC/CERL TR-16-28. Fort Leonard Wood Net Zero Water Program: Project Documentation for Fiscal Year 2015, Distribution D.

The Army Corps of Engineers (ERDCCERL) and Fort Leonard Wood are in the fifth year of planning and execution in support of installation sustainability. Net Zero Water support for Fort Leonard Wood in this planning effort focused on developing sustainability goals and objectives and defining a set of tasks to achieve them. A 1-day water workshop for installation staff devised a prioritized list of water topics to derive specific tasks to support water sustainability and reduce water consumption and cost to the installation. The 2015
Advanced meters have the ability to measure, record, and communicate data at regular intervals.

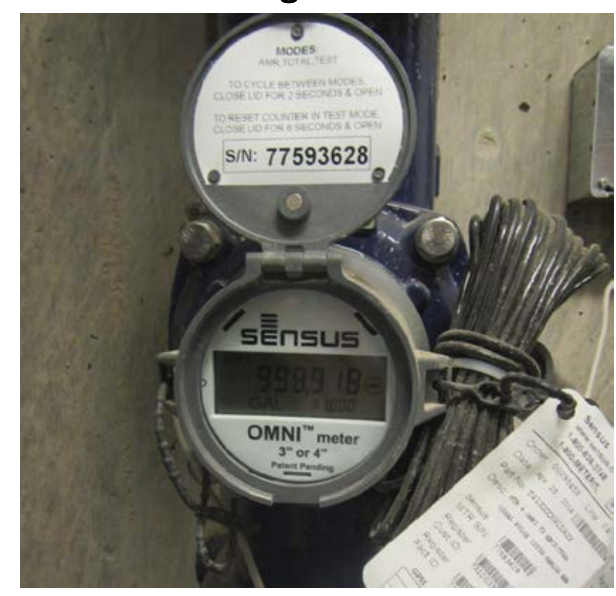
Net Zero Water effort updated the Buried No Longer analysis with local information, developed potable water leak detection recommendations, characterized high water use activities, calculated the energy cost of water, developed a strategic water-metering plan, and conducted a water analysis for 10 building types. Ongoing tasks from prior years included a water meter flow recorder analysis, stormwater planning for the Fort Leonard Wood Downtown project, water-metering recommendations, calculations of the real cost of water, and updates to the water technology retrofit guidelines. These tasks support efforts to reduce overall water use on the installation. 
Alexander M. Zhivov, Michael. P. Case, Richard. Liesen, et al. ERDC/CERL TR15-28. Demonstration of The Energy Component of The Installation Master Plan Using The Net Zero Planner, http://acwc.sdp.sirsi.net/client/en_US/search/asset/1049607

Alexander M. Zhivov, Michael. P. Case, Richard. Liesen, et al. 2015. ESTCP Final Report. Demonstrate Energy Component of The Installation Master Plan Using Net Zero Energy Installation Virtual Testbed, https://www.serdp-estcp.org/content/download/36615/350118/file/EW-201240-FR.pdf

This work demonstrated the energy master planning (EMP) concept and the ERDC-developed automated Net Zero Planner tool (NZP) at two DoD installations: U.S. Military Academy, West Point and Portsmouth Navy Shipyard. The NZP Tool incorporates the concept and various automated modules to integrate optimization across buildings, distribution, and generation systems. Results demonstrated that use of the NZP Tool reduces the time required for the analysis and the analysis cost to $\sim 35 \%$ of that required by the alternative current best practice.

Examples of community boundaries: (a) defined by building clusters; (b) defined by physical limitations.

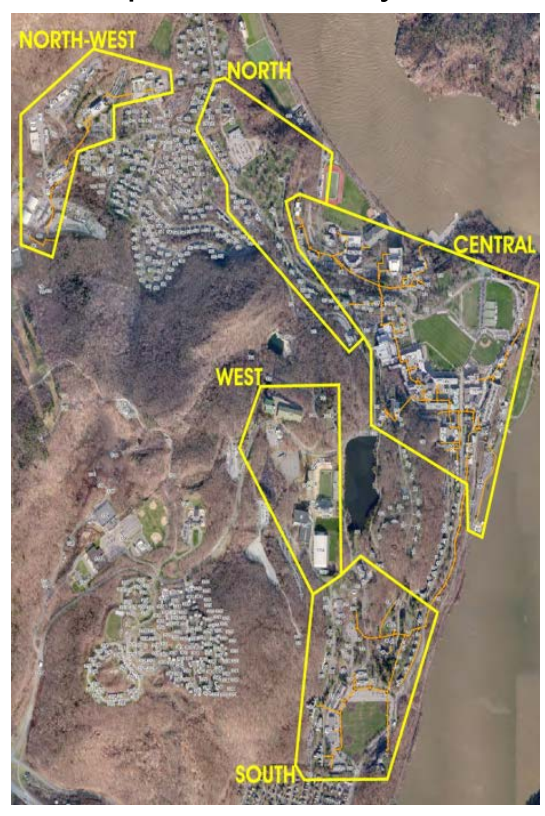

a.

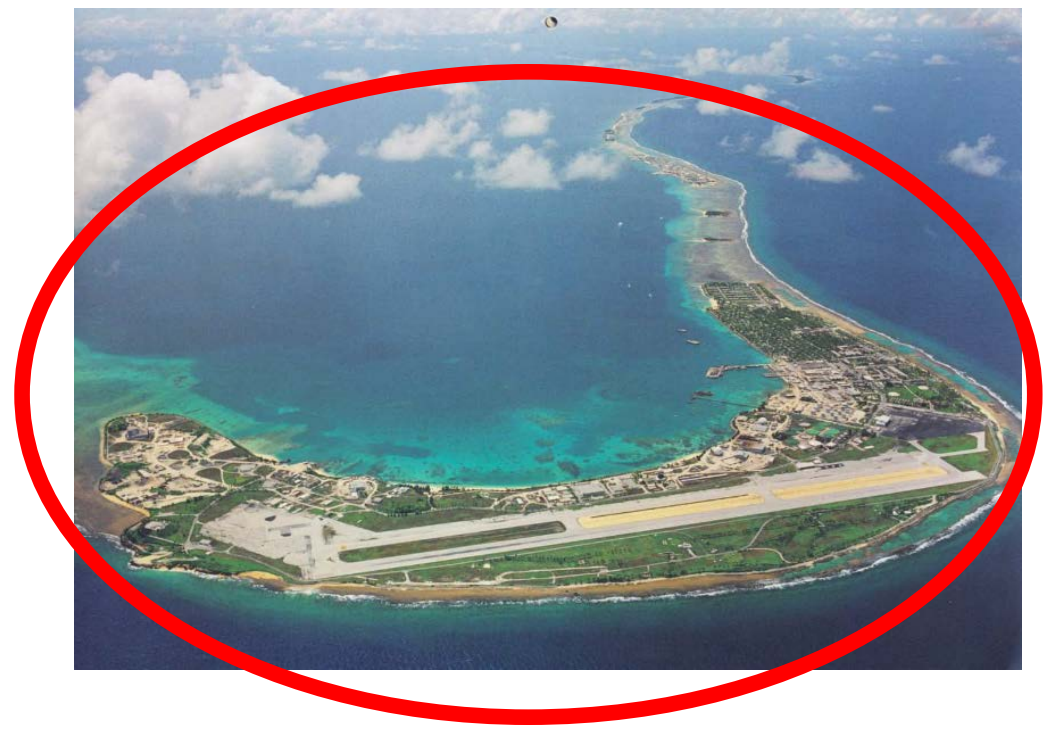

b. 
Lessons learned from the project were used to make many user interface changes throughout the program to facilitate the process, ease data entry, and help determine the information required to produce useful, relevant output reports. Funding for this demonstration was provided by the Environmental Security Technology Certification Program (ESTCP).

\section{Stephen D. Cosper. ERDC/CERL TR-15-21. Considerations for Net-Zero Waste Installations, http://acwc.sdp.sirsi.net/client/en_US/search/asset/1045912}

Today's Army faces significant threats to energy and water supply requirements both home and abroad. Addressing energy/ water security and sustainability is essential to mission accomplishment. The Army's goal is to manage "net zero installations," i.e., installations that operate not only on the basis of net zero energy, but Net Zero Water and Net Zero Waste as well. A net zero waste installation reduces, reuses, and recovers waste streams, converting them to resource values with zero landfill over the course of a year. This work outlines a plan for ERDC researchers to support the Army Net Zero Installation (NZI) vision by developing an NZI-Optimization tool that includes energy and water tracking and optimization features. This preliminary stage of work was undertaken to characterize Municipal Solid Waste (MSW), and describe the processes and technologies that may be integrated to support a NZW installation.

Example schematic of an MSW incinerator with energy recovery and air pollution control.

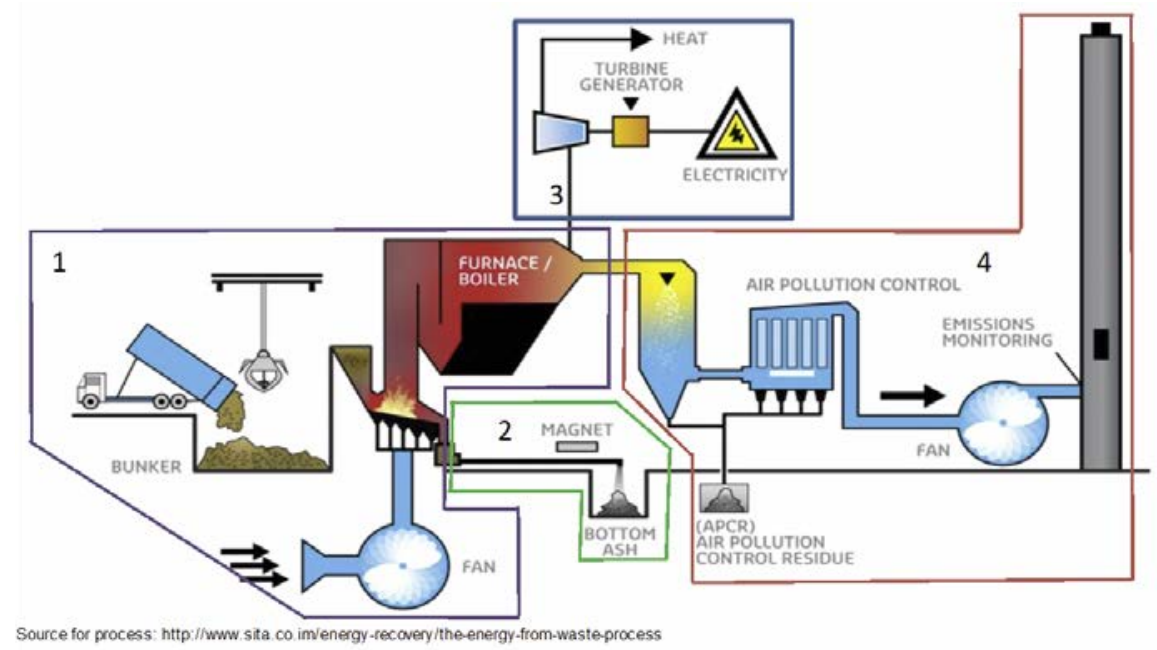




\section{Sustainable Energy Solutions}

DoD has established challenging goals to increase energy efficiency and reduce greenhouse gas (GHG) emissions of their installations in all five services with an ultimate goal of Net Zero Energy (NZE) installations. From a military capability systems support perspective, power and energy are critical to sustainability. They are a consideration in many facets of military operations. The purpose of this technology focus area is to identify the sustainability needs associated with integration of power and energy into military missions.

\section{Scott Lux. 2016. ERDC/CERL TR-16-2. Demonstration of a Robust Sensor System for Remote Condition Monitoring of Heat-Distribution System Manholes: Final report on Project F09-AR03, http://acwc.sdp.sirsi.net/client/en_US/search/asset/1048650}

This project demonstrated a wireless remote-monitoring system for detecting and reporting steam leaks or flooding in underground heat-distribution system (HDS) manholes. The system immediately notifies maintenance personnel of critical conditions that could indicate expensive energy losses and potentially serious damage to the HDS. Demonstrated at Redstone Arsenal, $\mathrm{AL}$, the system used durable temperature and water-level sensors for operating in very high heat and humidity. Remote-monitoring nodes in-

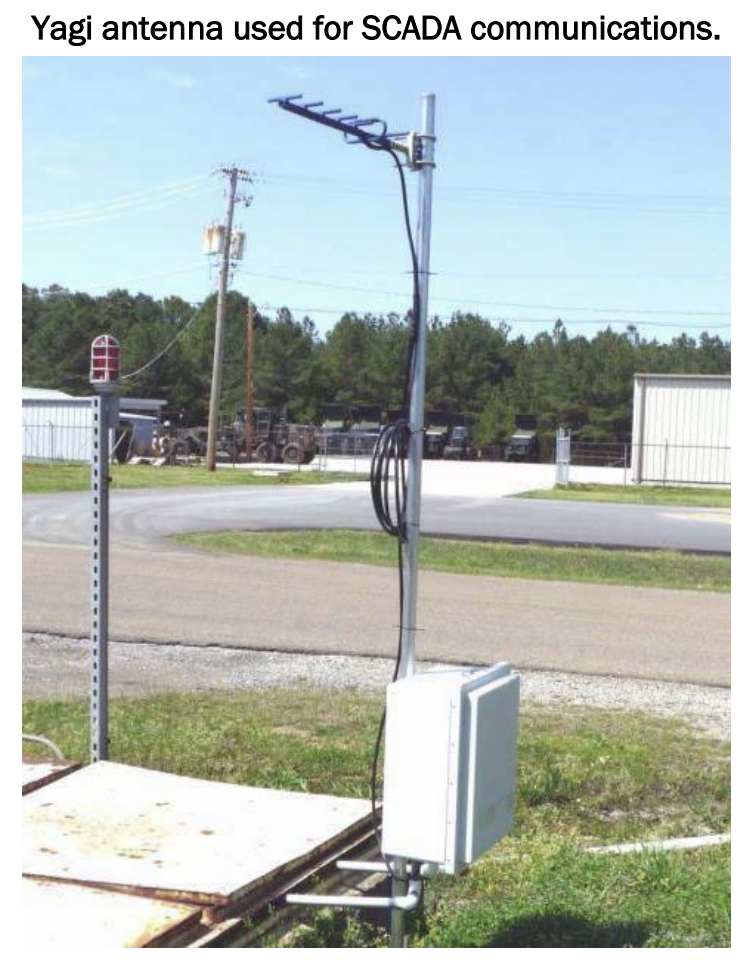
cluded remote transmitting units using one of two alternate wireless data technologies. Wireless $900 \mathrm{MHz}$ Ethernet service was installed and commissioned for eight manholes, linking them to the Redstone supervisory control and data acquisition (SCADA) system, but full integration with the SCADA system was not feasible given limitations on installation resources. Cellular data service was installed for six other manholes and commissioned successfully. Those nodes functioned for about 15 months to record 
ambient manhole conditions and email daily rollup data to the project point of contact (POC), verifying continuous operation. The functionality of the system design was validated, but important lessons were learned about electric service availability, line-of-sight antenna positioning for wireless Ethernet, and remote transmitting unit (RTU) installation. The return on investment for the cellular system was 94.6, potentially saving $\$ 534,000$ in maintenance over 30 years.

\section{Steven F. Daly. 2016. ERDC/CRREL TR-16-5. Characterization of the Lake Erie Ice Cover, http://acwc.sdp.sirsinet/client/en_Us/search/asset/1054567}

The developing offshore wind energy industry in Northern Ohio is looking to place wind turbines in Lake Erie. The floating lake ice that forms in Lake Erie each winter is a very imBathymetry of Lake Erie.

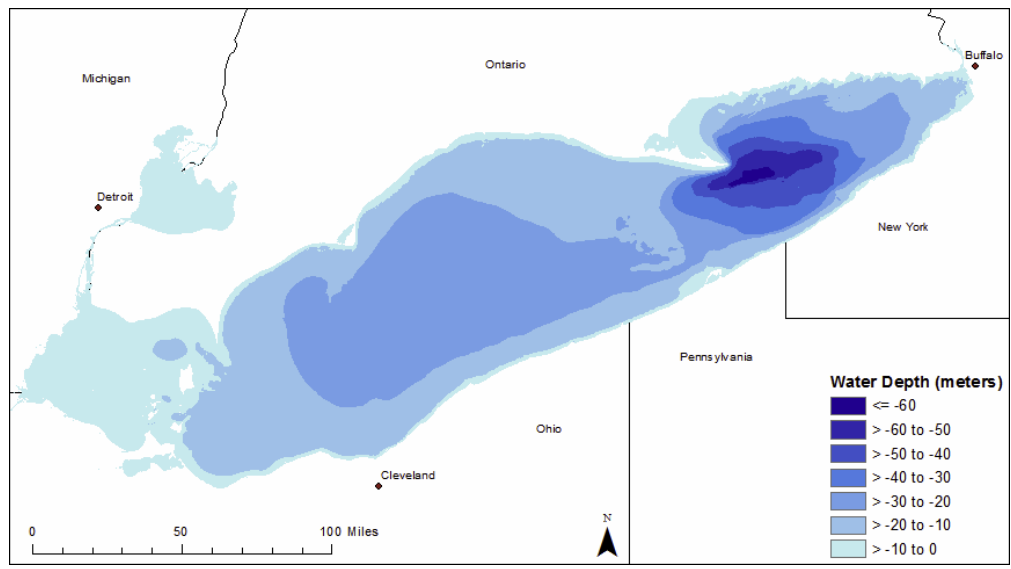

portant consideration for the design of the wind-turbine towers and for the foundations sited in the lake. This report uses historical meteorological and surface-ice-thickness observations, 41 years of ice chart information, and lake-bed surveys of ice scours to estimate the characteristics of the Lake Erie ice cover important to the design of offshore wind-turbine towers. These characteristics include the expected thickness of the ice cover due to thermal growth, the historical spatial and temporal distribution of the ice cover throughout the winter season; and the estimated consolidated layer thickness and maximum keel depths of ice ridges formed in the lake. The report also describes the results of an innovative satellite-based synthetic aperture radar survey that included multi-temporal acquisitions of the lake ice cover during the winter of 2014- 15. A stationary linear feature was evident in a time series of three spatially overlapping images, suggesting a grounded ice ridge. At that time of this publication, this is the first satellite-based evidence of ice ridges in Lake Erie. 
James H. Lever. 2016. ERDC/CRREL SR-16-2. Economic Analysis of the Greenland Inland Traverse (GrIT), http://acwc.sdp.sirsi.net/client/en_US/search/asset/1049988

The GrIT transports fuel and cargo over Ski-equipped LC-130 at Summit Station during cargo snow to resupply science stations on the Greenland ice sheet from Thule Air Base. GrIT offers an alternative to the traditional LC-130 airlift resupply from

Kangerlussuaq, Greenland. In this report, we assess the economics of GrIT relative to airlift resupply operations by comparing the costs of each mode to deliver the same fuel and cargo based on data from the 2012 and 2014 seasons.

Axy Pagan-Vazquez, Dahtzen Chu, John Straube, et al. ERDC/CERL TR-15-10. Using Thermal Bridging Factors in Energy Models, http://acwc.sdp.sirsinet/client/en_US/search/asset/1044033

Approximately 25\% of DoD's total energy use is consumed by buildingsover 577,000 buildings on more than 5300 sites. In 2006, DoD spent over $\$ 3.5$ billion for energy for fixed installations. The Energy Independence and Security Act (2007), and Energy Policy Act (2005) require the Army to dramatically reduce overall facility primary energy usage over the coming decades. The Army Energy Security Implementation Strategy (DA 2009) laid out the Department of the Army's strategy for large energy reductions. More recently, the Army published the "Army Vision for Net Zero," which states the ambitious goal of reaching Net Zero Energy at all fixed installations (ASA[IE\&E] 2012).

Achieving this goal will require the implementation of building envelope performance requirements not yet seen in the Federal government. The building envelope represents an area of much needed improvement in these facilities. Although guidance has already been published to encourage much more efficient building envelopes, it does not address the "thermal bridge," i.e., the part of an envelope in which heat transfer is greater than would be expected in a wall made up of common planar layers (e.g., gypsum wallboard, insulation, sheathing, and cladding). 
To help the

Army meet mandated energy reduction goals, this work developed a number of heat transmittance factors for use in including the heat loss of thermal bridging in the energy analysis of buildings. This work provides practical guide-
Convection loops can easily occur between the insulation and the structure in an interior retrofit if a gap is left.

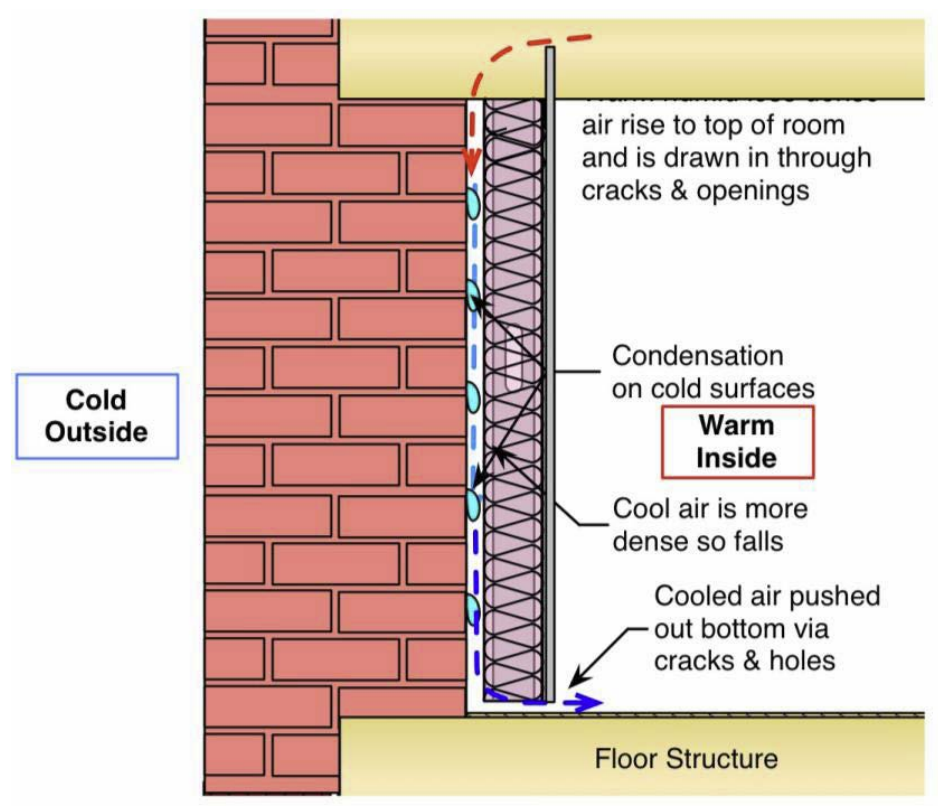

lines for the mitigation and reduction of thermal bridge problems in existing and new Army facilities. A wide range of building types was investigated from which nine common types were identified, and a number of important thermal bridge details were chosen for each. A list of details was compiled, from which 30 were chosen for detailed analysis based on their significance.

Elizabeth J. Gao, Jignesh Patel, Veera M. Boddu, et al. ERDC/CERL TR-15-23. Simulated Aging and Characterization of Phase Change Materials for Thermal Management of Building Envelopes, http://acwc.sdp.sirsi.net/client/en_US/search/asset/1045871

Because phase change materials (PCMs) can absorb or release heat when they undergo phase changes (solid to liquid, liquid to solid, or solid to gas), they are considered especially promising candidates for use in heating and cooling applications for building envelopes. This work investigated the stability of four commercially available PCMs, and developed an accelerated testing protocol to simulate the long-term performance of PCMs in an operational scenario. The selected PCM s were subjected to up to 5,400 cycles of thermal cycling at 90 minutes per cycle, over wide temperature ranges to simulate 20 years of use in building envelopes. At 3-4 week time intervals, the samples were taken from the thermal cycling chamber, analyzed, and the data obtained were compared to baseline (pre-cycling data). Thermal cycling in conjunction with Differential Scanning Calorimetry (DSC), Scanning Electron Microscope (SEM), and Thermogravimetric 
Analysis (TGA) appears to be a valid way to predict the long-term physical and thermal changes in a PCM samples based on short-term testing, and the 90-minute testing cycle appears to be adequate for the purpose of quickly simulating daily phase changes that the PCM would experience in operational environments.

Baseline latent heat values and freezing and melting transition temperatures were generally in accordance with the manufacturer's stated values although all PCM materials evaluated tended to lose some latent heat storage capacity as they underwent thermal cycling.

SEM images of Microencapsulated PCM pellets (Microtek 18D): (a) before thermal cycling, (b) after 1680 cycles (6.2 years), (c) after 3696 cycles (13.7 years), and (d) after 5400 cycles (20 years).
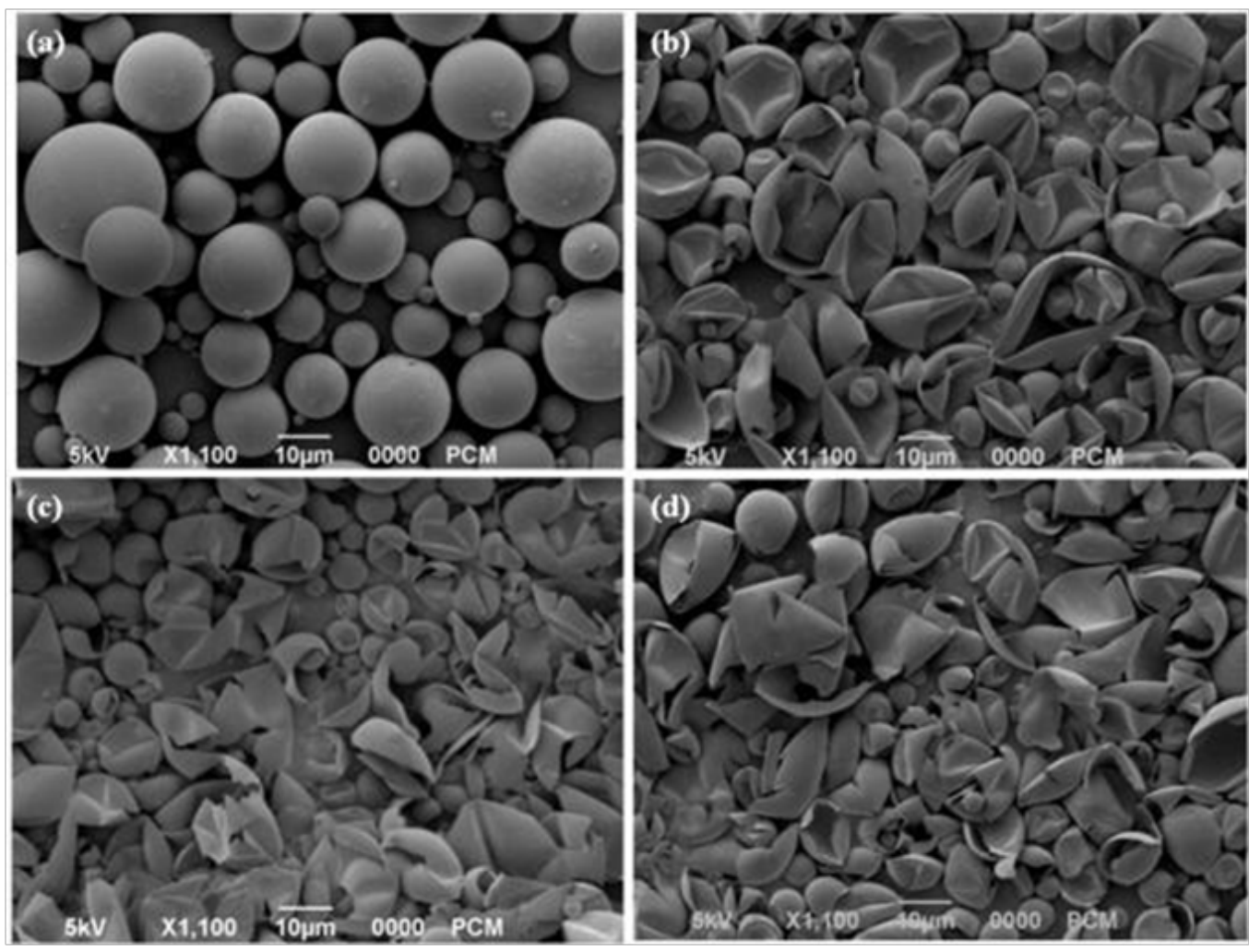
James P. Miller. ESTCP Report. Kinetic Super-Resolution Long-Wave Infrared (LWIR) Thermography Diagnostic for Building Envelopes, https://www.serdp-estcp.org/content/download/34401/332473/file/EW-201241-FR.pdf

James P. Miller and Navi Singh. ERDC/CERL TR-15-17. Kinetic SuperResolution Long-Wave Infrared (LWIR) Thermography Diagnostic for Building Envelopes: Scott AFB, IL, http://acwc.sdp.sirsi.net/client/en_US/search/asset/1045552

James P. Miller and Navi Singh. ERDC/CERL TR-15-18. Kinetic SuperResolution Long-Wave Infrared (LWIR) Thermography Diagnostic for Building Envelopes: Camp Lejeune, NC, http://acwc.sdp.sirsi.net/client/en_US/search/asset/1045553

Each year, DoD buildings waste millions of dollars' in energy lost through leaks in building envelopes. Identifying the source of this wasted energy has historically been time consuming and prohibitively expensive for large scale energy analysis. Specially equipped scanning vehicle.

This work used an inde-

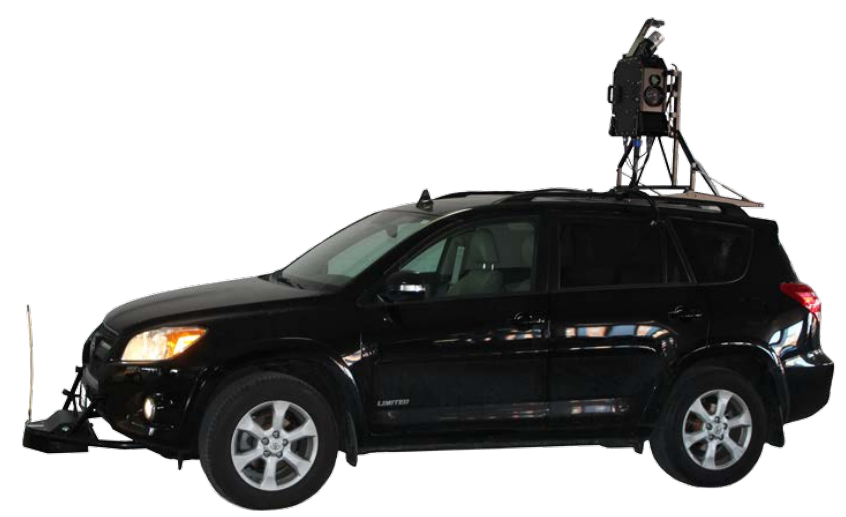
pendently developed drive-by thermal imaging solution that can enable DoD to achieve cost effective energy efficiency at much greater scale than other commercially available techniques of measuring energy loss due to envelope inefficiencies from the built environment. A multi-sensor hardware device is attached to the roof of a customized vehicle to rapidly scan hundreds of buildings in a short period of time.

At Scott Air Force Base, the unit identified over 3,000 distinct building feature components (doors, windows, soffits, etc.) on buildings across the base. At U.S. Marine Corps Base Camp Lejeune, the unit identified over 2500 distinct building feature components identified across various buildings throughout the base. These features were categorized by type and surface temperature to provide an in-depth analysis of each building's envelope energy profile. This report includes an in-depth analysis of 30 buildings at each installation, recommends specific energy conservation measures (ECMs), and quantifies significant potential return on investment. 
At U.S. Marine Corps Base Camp Lejeune, the unit identified over 2500 distinct building feature components identified across various buildings throughout the base. These features were categorized by type and surface temperature to provide an in-depth analysis of each building's envelope energy profile. This report includes an in-depth analysis of 30 buildings at each installation, recommends specific ECMs, and quantifies significant potential return on investment.

L. D. Stephenson, Andrew Heffron, Brenda B. Mehnert, et al. ERDC/CERL TR15-8. Prediction of Long Term Degradation of Insulating Materials, http://acwc.sdp.sirsi.net/client/en_US/search/asset/1043709

Advanced insulation materials provide resistance to heat flow. Properly insulating shelters can reduce heating and cooling costs, as well as improve comfort. However, the long-term performance of insulation materials is relatively unknown. This research investigated the long-term performance of five commercially available insulation materials including nonwoven insulation liner, aerogel blankets, closed-cell spray polyurethane foam (ccSPF), extruded polystyrene (XPS), and fiberglass batt. Accelerated aging simulation experiments were conducted in an environmental chamber. All materials were subjected to 5 weeks in the chamber and exposed to various temperature and humidity conditions. Thermal conductivity using a heat flow meter apparatus and corresponding R-values of each material were calculated. The results indicate that moisture absorption was a major contributor to changes in the thermal properties of the materials. Additional degradation in R-values in ccSPF was caused by loss of blowing agent over time. The results of this research are expected to help formulate an accelerated aging methodology that allows reliable prediction of longterm advanced insulation materials performance.

James P. Miller, David M. Underwood, Laura E. Curvey, et al. ERDC/CERL TR15-7. Level I Energy and Water Survey, ERDC-CERL, Champaign, IL, http://acwc.sdp.sirsinet/client/en_US/search/asset/1043646

This energy and water survey at ERDC-CERL identified energy and water inefficiencies and waste, and proposed energy and water-related projects that would enable the installation to better meet mandated energy and water reduction requirements. The survey included a Level I energy and water optimization assessment study, which reviewed the Main Complex and other buildings within the secured perimeter. The leased American Telephone \& Telegraph (AT\&T) facility was not included in the study since ERDC-CERL intends to vacate the AT\&T facility within the next 2 years. 
The ERDC-CERL Forward Operating Base Laboratory (EFOB-L) facilities on the north edge of the ERDC-CERL campus were not included in the study since these facilities currently receive very minimal electrical support from the Main Complex.
Utilis TM60 shelter with nonwoven composite insulation (Thinsulate ${ }^{\mathrm{T} M}$ ) liner (Camel Manufacturing, Pioneer, $\mathrm{TN}$ ).

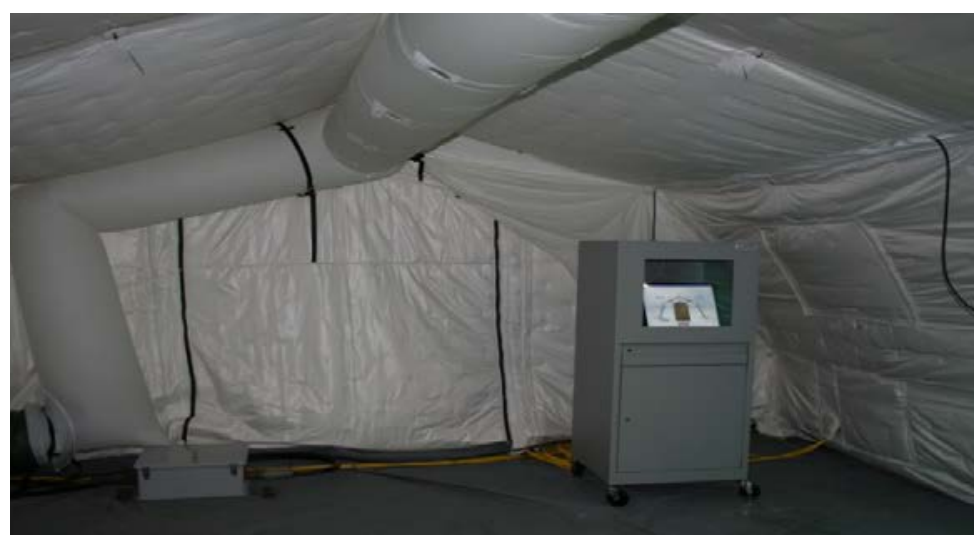

The study identified nine economically viable ECMs that, if implemented, would substantially reduce ERDC-CERL's annual energy consumption. These ECMs are presented in three groups according to the size of the required investment for each ECM. The study also identified four economically viable ("low cost") water conservation measures (WCMs) that, if implemented, would reduce ERDC-CERL's annual water use by up to $207 \mathrm{kgal} / \mathrm{yr}$.

Sean W. Morefield and Jorge L. Alvarado. ERDC/CERL MP-15-1. Field Validation of Microencapsulated Phase-Change Material Slurries as HeatTransfer Fluids, https://www.serdp-estcp.org/content/download/35686/342045/file/EW201154-Technical\%20Memo.pdf

Thermal management of facilities and processes on military installations requires the continual pumping of large volumes of a heat-transfer fluid (HTF). Laboratory studies have shown that HTFs infused with microencapsulated phase change materials (MPCMs) have a higher heat-carrying capacity than conventional HTFs; the use of MPCMs could reduce the required fluid-flow rate and, thus, system power costs. This study demonstrated the performance of MPCM slurries under continuous pumping conditions in full-scale applications at two U.S. military installations. An instrumented test loop was temporarily integrated with ground-source heat-exchange systems at Fort Hood, TX, and Fort Dodge, IA, to compare the thermal performance and pumping-power requirements of conventional HTFs and MPCM slurries.

Premature capsule breakage during early tests was addressed by thickening capsule walls and replacing the centrifugal circulation pump with a 
progressive cavity pump to reduce mechanical shear stresses. MPCM heatcarrying capability varied with mass ratio between capsule wall and phase change material. The heat-transfer coefficient of performance for MPCMs was seen to improve at least $10 \%$ over conventional HTFs, with system power-consumption reductions of at least 3\%. An economic assessment indicates that implementation of MPCMs as a drop-in application could provide a 1.77 return on investment ratio. However, results suggest that the technology is not mature enough to recommend for widespread drop-in implementation at this time.

Victor F. Medina. Richard J. Scholze, Scott A. Waisner, et al. ERDC SR-15-2, Energy and Resource Recovery from Wastewater Treatment: State of the Art and Potential Application for the Army and the DoD, http://acwc.sdp.sirsi.net/client/en_US/search/asset/1043946

This study assessed energy and resource recovery from wastewater treatment and short- and long-term opportunities and impacts for the Army and DoD in general. The Examples of two simple anaerobic digester reactors: covered lagoon (left) and bag reactors (right).

organic mate-

rial in

wastewater

contains in-

herent energy.

The challenge

is concentrat-

ing and recov-

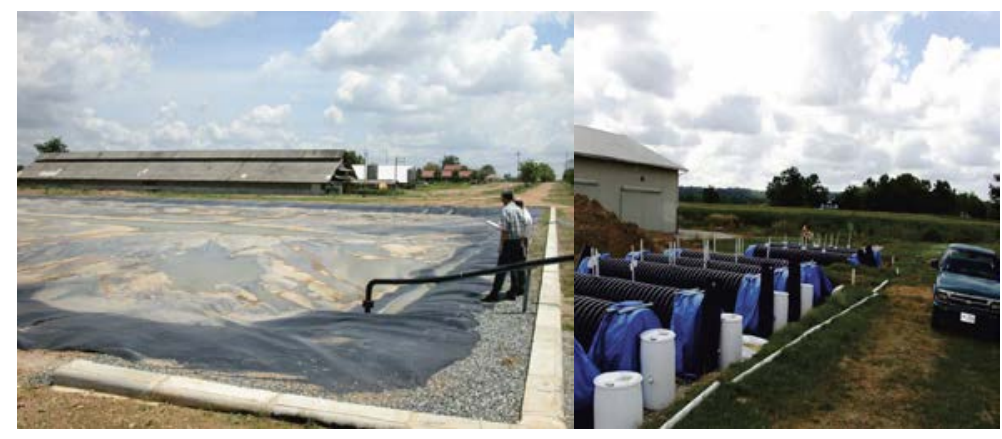

ering this en-

ergy. Of the several methods available, anaerobic digestion (either of the sludge, or directly applied to the wastewater using an Upflow Anaerobic Sludge Blanket or a similar reactor) is the most advanced and can be readily applied to existing military installations or to contingency operations. Recovery of chemical products is another option or wastewater treatment. The most commonly recovered products are nutrients, in the form of nitrogen $(\mathrm{N})$ and phosphorus $(\mathrm{P})$. The simplest way is to recycle the collected and digested biosolids (sludges), either for direct soil application or by incorporation into compost. Resource recovery from wastewater may eventually include biopolymers that could make bioplastics or valuable nanometals that are increasingly found in consumer products. Many of the energy recovery technologies and most of the resource recovery approaches (beyond simple biosolids recovery) require large scale operations to be 
economically viable at this time. Wastewater treatment facilities that serve Army and other DoD installations tend to be relatively small, limiting the application of many approaches that might be practicable in the civilian sector. The report recommends that ERDC should focus research on technologies that could be economically applied to smaller treatment plants on the order of 3 to $10 \mathrm{mgd}$.

Brendan A. West, Charles C. Ryerson, and Keran J. Claffey. 2015. ERDC/CRREL TR-15-18. NHARNG Wind Resource Assessment: Center Strafford Training Center, http://acwc.sdp.sirsi.net/client/search/asset/1047667

The New Hampshire Army National Guard (NHARNG) training facility in Center Strafford, $\mathrm{NH}$, wishes to supply at least $25 \%$ of its energy needs with renewables by 2025 to meet Army and DoD energy goals. They commissioned the Cold Regions Research and Engineering Laboratory (CRREL) to determine the feasibility of wind energy meeting this requirement. Aiming to meet industry standards for assessment, CRREL acquired meteorological wind data from J une 2012 through May 2014; performed data quality control; estimated turbulence, wind shear, and speed distributions; and estimated energy production and payback periods for five $100 \mathrm{~kW}$ wind turbines. The best performing turbine assessed at a hub height of $37 \mathrm{~m}$ could provide $52 \%$ of the site's annual electric power needs with a payback of approximately 18 to 19.6 years. However, extrapolated long-term wind speeds suggest the best performing turbine assessed could provide $71 \%$ of the site's annual electric power needs; and the payback would drop to approximately 14 years. CRREL also assessed the feasibility of a comparable solar energy system at Center Strafford, and the payback for a fixed-array system is 14-16 years and 11 years for a two-axis array system. 


\section{Sustainable Water \& Waste Resources}

In recent years, military installations have been impacted by conditions of increasing demand and decreasing supply of high quality fresh water. Urban growth adjacent to installations has combined with prolonged regional droughts to place key military missions at risk due to limited availability of this vital resource. Regional competition for water threatens continued availability of adequate water both on post and in adjacent urban areas.

This focus area addresses access to, and the sustainable use of, water resources. Activities include understanding water resources status, quantities and qualities; conservation approaches and technologies; water reuse technologies and approaches; and other capabilities to improve and enhance the availability and quality of water as a sustainable resource.

Curtis Fey. 2016. ERDC TR-16-17. Organic Waste Diversion Guidance for U.S. Army Installations, http://acwc.sdp.sirsi.net/client/en_US/search/asset/1052266

Methods of organic waste diversion currently being employed by U.S. Army installations were reviewed to provide recommendations and case studies as well as identify best practices. As part of the Army's Net Zero Installation Strategy, it is essential that installations reduce the amount of solid waste they send to landfills. Food and other organic waste, such as yard trimmings and wood residuals, are a major component of the solid waste

In-vessel food waste composting system.

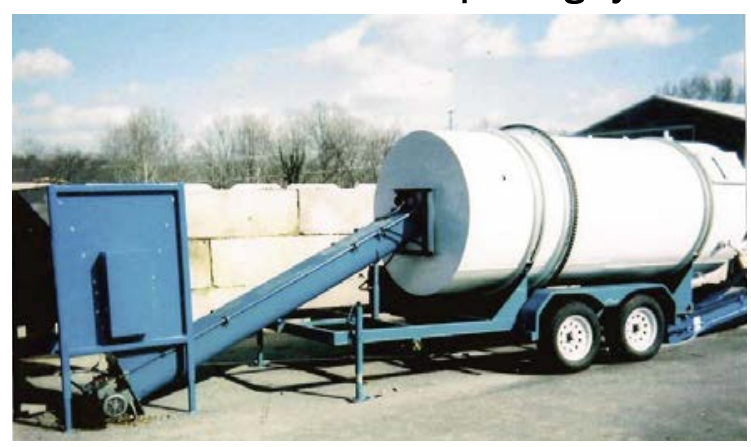
generated by installations that can be reduced, repurposed, or transformed. Both on- and off-post diversion alternatives are discussed, and case studies from U.S. military installations are provided as examples. Wherever possible, examples of documentation language (e.g., contract statements, Memorandums of Agreement [MOAs]/ Memorandums of Understanding [MOUs]) are provided for contractor support of diversion activities. The report identifies mature and available small-scale organic waste management technologies, and the associated benefits, concerns, and conditions for their successful use on an installation are examined. An excel-based decision tree accompanies the report to provide guidance for 
selecting technologies or practices that suit an installation's specific capacities and preferences. The analysis provided is applicable to any Army installation or other sizable organization in the early stages of considering how to divert organic waste from a landfill.

Ryan Busby. 2016. ERDC/CERL TR-16-1. Demonstration of Combined Food and Landscape Waste Composting at Fort Leonard Wood, MO: Fort Leonard Wood Installation Strategic Sustainable Plan, http://acwc.sdp.sirsi.net/client/en_US/search/asset/1048226

While nearly $90 \%$ of landscape wastes are recovered and processed into soil amendments and organic fertilizers using simple composting technologies, less than $3 \%$ of food wastes are recovered and recycled and the remainder are landfilled at considerable cost. Executive Order 13101 calls for DoD to incorporate waste prevention and recycling into their daily operations. Although most Army installations have effective landscape waste collection and recycling capabilities, they capture very little food waste for recycling. To initiate the incorporation of organic waste treatment technologies into daily activities at Army installations, this work investigated the logistical and economic feasibility of this technology and demonstrated food waste composting at Fort Leonard Wood, MO.

Jacob F. Berkowitz. 2016. ERDC/EL TR-16-6. Identifying Areas of Potential Wetland Hydrology in Irrigated Croplands Using Aerial Image Interpretation and Analysis of Rainfall Normality, http://acwc.sdp.sirsi.net/client/en_US/search/asset/1049990

The following report provides a framework for evaluating areas with potential wetland hydrology in irrigated and formerly irrigated croplands. The document is designed to provide insight into the complexity of identifying irrigated wetlands and to support current guidance. Additionally, the analysis conducted helps to identify and refine areas that can be targeted for future investigation, inHighlighted area displays evidence of a shift in vegetation, indicating potential soil saturation.

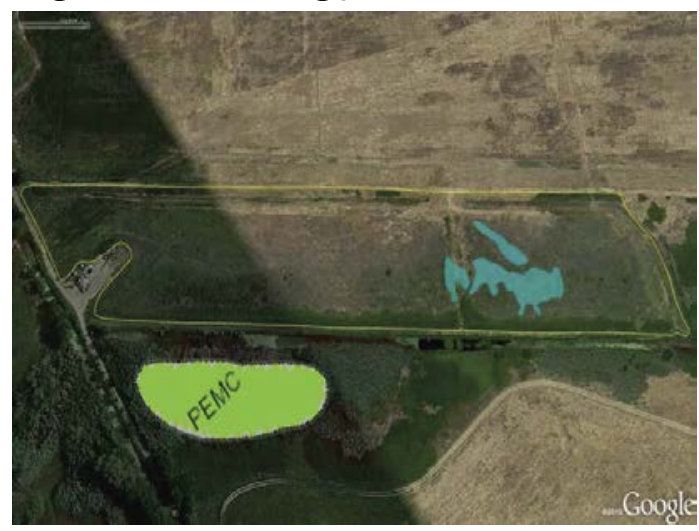
cluding the installation of onsite groundwater monitoring equipment. The information herein supports and supplements current approaches and is not intended to replace or supersede current USACE national, division, or 
district level guidance for making wetland determinations in irrigated croplands. The procedures in this document should not be the sole basis for making wetland determinations for the purposes of the Clean Water Act; rather, these procedures are intended to supplement existing guidance and provide supporting information for making wetland determinations.

Victor F. Medina, Richard J. Scholze, Scott A. Waisner, et al. ERDC SR-15-2. Energy and Resource Recovery from Wastewater Treatment: State of the Art and Potential Application for the Army and the DoD, http://acwc.sdp.sirsinet/client/en_US/search/asset/1043946

This report summarizes a study to assess energy and resource recovery from wastewater treatment and assess short- and long-term opportunities and impacts for the Army and DoD in general. The organic material in wastewater contains inherent energy. The challenge is concentrating and recovering this energy. Several methods are available; of these, anaerobic digestion (either of the sludge, or directly applied to the wastewater using an Upflow Anaerobic Sludge Blanket or a similar reactor) is the most advanced and can be readily applied to existing military installations or to contingency operations.

Recovery of chemical products is another option for wastewater treatment. The most commonly recovered products are nutrients, in the form of nitrogen $(\mathrm{N})$ and phosphorus $(\mathrm{P})$. The simplest way is to recycle the collecied and digested biosolids (sludges), either for direct soil application or by incorporation into compost. Resource recovery from wastewater may eventually include biopolymers that could make bioplastics or valuable nanometals that are increasingly found in consumer products.

Many of the energy recovery technologies and most of the resource recovery approaches (beyond simple biosolids recovery) require large scale operations to be economically viable at this time. Wastewater treatment facilities that serve Army and other DoD installations tend to be relatively small, limiting the application of many approaches that might be practicable in the civilian sector. ERDC should focus research on technologies that could be economically applied to smaller treatment plants on the order of 3 to $10 \mathrm{mgd}$. 


\section{Sustainable Facilities and Infrastructure}

The purpose of this focus area is to help USACE, the Army, and DoD work toward achieving net zero and sustainable planning, design and development goals. The focus area team leaders are part of the Sustainable Design and Development Directory of Expertise (SDD DX) that the Corps established to provide support in developing criteria, research and development, design and construction support services, and training and advisory assistance. In this technology area, CASI also provides support and collaboration with the U.S. Green Building Council (USGBC) and other organizations involved in sustainable design and development (SDD).

\section{Kathleen Jones. 2016. ERDC/CRREL MP-16-1. Effect of Arctic Amplification on Design Snow Loads in Alaska: SERDP RC-2435, http://acwc.sdp.sirsi.net/client/en_US/search/asset/1051466}

DoD seeks an improved understanding and capacity to respond to potential climate change impacts on built infrastructure in Alaska. Other studies have hypothesized that Arctic amplification, the rapid warming of the Arctic compared to the northern hemisphere, causes more persistent weather patterns at midlatitudes, which increase Snow Telemetry site at Little Chena Ridge, Fairbanks County, AK.

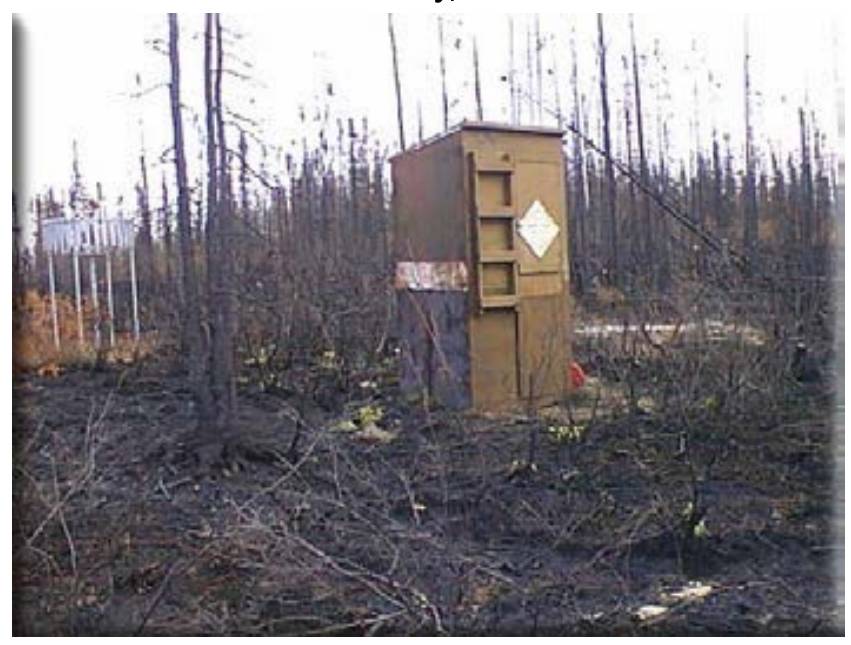
the probability of extreme weather due to drought, flooding, cold spells, and heat waves. Annual maximum snow loads, resulting from the accumulation of snow throughout the winter season, may be strongly influenced by persistent weather patterns. We investigated the effects of these persistent weather patterns on annual maximum snow loads and the resulting design snow loads for buildings. 


\section{Lynette A. Barna. 2016. ERDC/CRREL TR-16-7. Assessment of Asphalt Concrete Reinforcement Grid in Flexible Pavements, http://acwc.sdp.sirsi.net/client/en_US/search/asset/1049726}

This report investigated the application of accepted methods of pavement structural evaluation to independently assess the potential structural benefit of asphalt geogrid reinforcement of an operational flexible highway pavement. The asphalt interlayer consisted of an elastomeric polymer coated fiberglass grid with an open configuration. The reinforcing grid was installed in the asphalt layer during construction of a maintenance overlay and has been subjected to trafficking for several years. Our structural evaluation included a geotechnical investigation and non-destructive testing using a falling weight deflectometer. Field testing was conducted when both air temperatures were above $50^{\circ} \mathrm{F}$ and no recent precipitation events had occurred. Standard testing methods were applied during the field data collection and back-calculation procedure. The back-calculation results showed no clear quantifiable benefit from including the reinforcing grid in the asphalt layer, but this study developed a methodology to test and evaluate in situ flexible pavements with asphalt grid reinforcement. We recommend that a future structural evaluation be completed to monitor any changes in the pavement's performance.

Terry D. Melendy. 2016. ERDC/CRREL TR-16-9. Summit Station Skiway Cost Analysis, http://acwc.sdp.sirsi.net/client/en_US/search/asset/1050687

Summit Station, Greenland, is home to a $5120.6 \times$ $61.0 \mathrm{~m}(16,800 \times 200 \mathrm{ft})$ skiway that acts as the lifeline for research conducted for the National Science Foundation. The LC-130 aircraft is the primary airframe depended on, each
Each season, the skiway is constructed and maintained by a Pisten Bully 300W

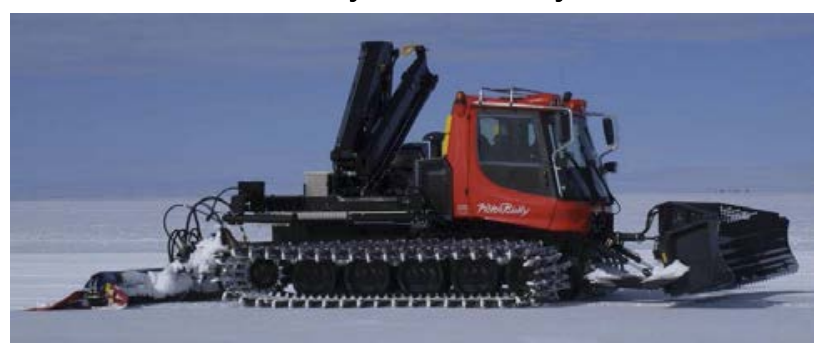


season delivering over 400,000 lb of cargo, personnel, and fuel to this remote location. A majority of the research activities takes place from midApril to August while the station is open for the summer season. Over the past three seasons, the skiway's ability to handle this frequency of flights has increased with the implementation of new equipment and techniques, resulting in fewer jet-assisted takeoffs and longer periods of maximum allowable cargo loads. To explore further skiway improvement and cost saving techniques, this report reviews alternative maintenance and construction options based on other skiways located in Greenland and alternative available aircraft that currently operate in this region. Additionally, we were provided the entire season's total labor associated with the skiway operation and data for the cost associated with the skiway, which allowed us to quantify the current and available options. This is the first time that these metrics have been recorded and analyzed.

Steven A. Arcone. 2016. ERDC/CRREL TR-16-14. Ground-Penetrating-Radar Profiles of Interior Alaska Highways: Interpretation of Stratified Fill, Frost Depths, Water Table, and Thaw Settlement over Ice-Rich Permafrost, http://acwc.sdp.sirsi.net/client/en_US/search/asset/1050926

In early spring 2014, we recorded ground-penetrating-radar (GPR) profiles along several highways in interior Alaska to determine present and potential damaging thaw settlement, which could help site and design infrastructure in permafrost terrains. We used GPR pulses centered near 100, 150, and $320 \mathrm{MHz}$. Comparative profiles of electrical resistivity, historical GPR profiles, and limited borehole information aided interpretations. Beneath the Elliott Highway, Goldstream Road, and the Old Steese Highway, construction fill was recognized by its stratification; and frost depth and water table horizons

HF shows concentric harmonic folds; AHF shows anharmonic folds, which indicate long progressing settlement.

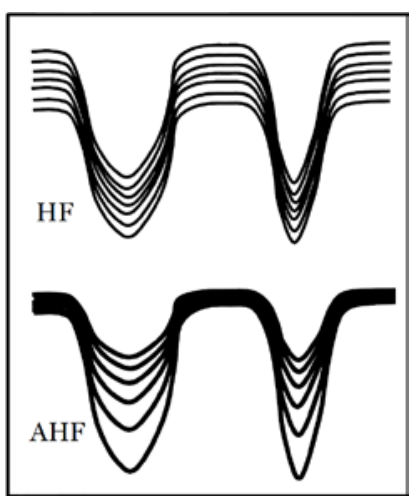
were recognized by phase attributes of the reflected pulse, as dictated by dielectric permittivity contrasts, relative depths, and continuity. Undulating fill stratification indicated thaw settlement, caused by melting of buried ice. We interpreted various stratigraphic folds to represent cases of active, recent, remediated and historical settlement. A section along the Tok Cutoff Road revealed the top and bottom of massive ice within glacial moraine. Signal penetration was greatly 
reduced beneath the water table, and the permafrost table was not detected. This information is valuable for highway maintenance and new construction planning, especially in remote locations where information on permafrost and ice features are limited.

Adam Smith. 2016. ERDC/CERL CR-16-1. Matthew Jones House: Recommendations for Treatment, http://acwc.sdp.sirsi.net/client/en_US/search/asset/1049989

The MatthewJ ones House (MJ H) is located on J oint Base LangleyEustis (Eustis) (JBLE-E), VA. The house is a Virginia Historic Landmark (121-0006) and also listed on the National Register of Historic Places (\#69000342). All buildings, especially historic ones, require regular, planned, and appropriate maintenance and repair. After identifying a variety of issues with the house for J BLE-E, architectural historians at the U.S. Army Engineer Research and Development Center-Construction Engineering Research Laboratory (ERDC-CERL) requested technical assistance from the National Center for Preservation Technology and Training (NCPTT) with analyzing existing materials, providing specifications for appropriate treatment materials, and making priority-level recommendations for $\mathrm{MJ} \mathrm{H}$ treatment by taking into account conditions and budget. The work's scope included the roofing, masonry, and Heating, Ventilating, and Air-Conditioning (HVAC) systems of the structure. This report summarizes the research and findings by the NCPTT. It also includes an engineer's report and other supplemental information. This work will continue to assist J BLE-E in maintaining this historic building.

\section{Glenn M. Suir. 2016. ERDC TR-16-15. Landscape Evolution of the Oil Spill Mitigation Sand Berm in the Chandeleur Islands, Louisiana, http://acwc.sdp.sirsi.net/client/en_US/search/asset/1051349}

The failure of the Macondo-252 well and explosion of the Deepwater Horizon oil rig resulted in the release of approximately 185 million gallons of crude oil into the Gulf of Mexico. As part of the emergency response plan, the Louisiana Office of Coastal Protection and Restoration proposed (and later constructed) sand barriers to reduce the amount of oil from reaching 
the Chandeleur Islands and inland wetlands, thereby protecting these sensitive ecosystem resources. This study provided general measures of the sand berms resilience, performance, and potential impacts to the Chandeleur Islands. Geographic Information System (GIS) and remote-sensing techniques were used to quantify changes in sand berm areal extent over time; provide shoreline, habitat, and landscape assessments of the Chandeleur Islands; and assess elevation changes and potential reworking of berm sediment into the island system. The sand berm provided short-term benefits and short-term advancement of the island's shoreline position, but the majority of those benefits were ephemeral since the berm experienced rapid degradation. The speed and degree of degradation were primarily the results of Tropical Storm Lee and Hurricane Isaac and of the construction of the berm in high-energy open water environments. Ultimately, the berm was unsuccessful in providing a barrier to retard oil from reaching the island or oil migrating into Chandeleur Sound and beyond.

Richard G. Lampo. 2016. ERDC/CERL CR-16-3. Field Testing and Summary Report for Road 5 (Morris Road) over Road 3 (Toftoy Throughway) at Redstone Arsenal, AL: Contractor's Supplemental Report for Project F09AR16, http://acwc.sdp.sirsi.net/client/en_US/search/asset/1051686

Cyclic loading and weathering of reinforced concrete bridge decks causes corrosion of reinforcement steel, which leads to cracking, potholes, and other problems. Under the DoD Corrosion Prevention and Control Program, a deteriorated concrete bridge at Redstone Arsenal, AL, was selected to demonstrate and validate a glass-fiber reinforced polymer (GFRP) composite deck system that uses no reinforcement steel. Project results were published as ERDC/ CERL TR-16-6 (August 2016). On completion of the new GFRP composite deck system, Bridge Diagnostics, Inc. was contracted to perform load testing to confirm that the bridge meets the structure's original 36-ton (HS-20) load rat-

Typical strain gauge and linear varying differential transformer at midspan of fiber-reinforced polymer deck panel.

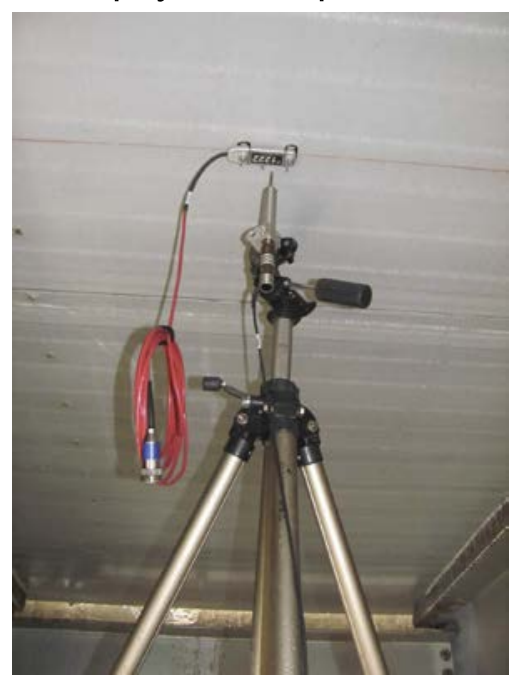
ing and performance criteria for deflection and strain. This report documents the load test methods used by BDI and the results. The test results indicate that the demonstrated GFRP composite deck system met the strength design specifications and passed the deflection criteria. 
Steven Sweeney. 2016. ERDC/CERL CR-16-4. Field Testing and Load Rating Report for Bridge No. 4, Composite Grid Reinforcement of Concrete Deck, at Fort Knox, Kentucky: Contractor's Supplemental Report for Project F12-AR01, http://acwc.sdp.sirsi.net/client/en_US/search/asset/1051826

The Army has 1,500 vehicular bridges on its installations, with many experiencing high maintenance or replacement costs due to corrosion of the steel structure or of the reinforcing bar in the concrete deck. Under the DoD Corrosion Prevention and Control Program (Project F12-AR01), a span of Bridge No. 4 at Fort Knox, KY, was selected to demonstrate and validate a fiber-reinforced polymer (FRP) composite grid deck system, which does not use any rein-

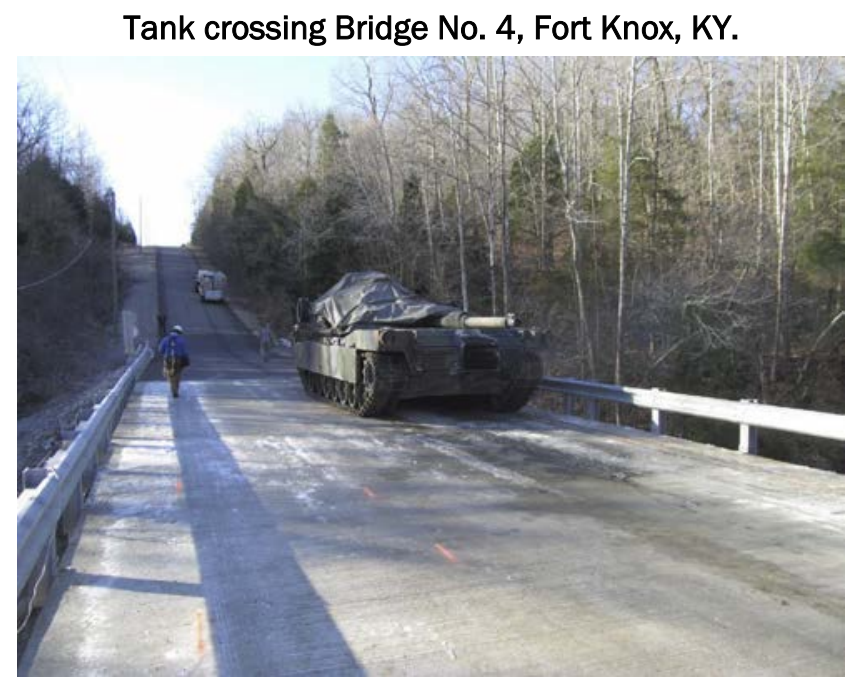
forcement steel. The results of that project were published as ERDC/ CERL TR-16-21 (September 2016). Bridge Diagnostics, Inc. (BDI) of Boulder, $\mathrm{CO}$, was subcontracted to perform load testing and rating for the newly completed composite bridge deck system to confirm that the bridge span met its required load rating and performance criteria for deflection and strain. Structural testing of the bridge was performed at the end of construction and after 12 months of exposure. Results showed the bridge met all design specifications and load ratings.

Richard G. Lampo. 2016. ERDC/CERL CR-16-5. Field Testing and Load Rating Report for Bridge No. 4, Hybrid Composite Beam Span, at Fort Knox, Kentucky: Contractor's Supplemental Report for Project F12-AR15, http://acwc.sdp.sirsi.net/client/en_US/search/asset/1051767

The Army has 1,500 vehicular bridges on its installations, with many experiencing high maintenance or replacement costs due to corrosion of the steel structure or of the reinforcing bar in the concrete deck. Under the DoD Corrosion Prevention and Control Program (Project F12-AR15), a span of Bridge No. 4 at Fort Knox, KY, was selected to demonstrate and validate a new corrosion-resistant hybrid composite bridge beam. 
Project results were published as ERDC/ CERL TR-16-22 (September 2016). Bridge Diagnostics, Inc., Boulder, CO, was subcontracted to perform load testing and rating for the new bridge beam project to confirm that the replacement bridge span met its required load rating (HL-93) and performance criteria for deflection and strain. Results showed that the bridge met all design specifications and load ratings.

\section{Susan Enscore, 2016. ERDC/CERL MP-16-1. Historic American Engineering Record (HAER) Level II Documentation of Launch Complexes 1/2, 3/4, 9/10, 14, and 34 at Cape Canaveral Air Force Station, Florida, http://acwc.sdp.sirsinet/client/en_US/search/asset/1050427}

This report presents HAER Level II documentation of Launch Complexes 1/2, 3/4, 9/ 10, 14, and 34, Cape Canaveral Air Force Station (CCAFS), FL. These facilities played an important role in the American missile and manned space programs that began largely as a result of the Cold War. As the arms race expanded in the 1950s and 1960s, missile systems with increasing range and destructive power were deployed on American and foreign soil. Bringing these systems to operational readiness required long, complicated testing programs and specialized facilities to support them. A national effort to put men on the moon also required specialized facilities at Cape Canaveral. These five complexes were constructed in the 1950 s and early 1960s. Launch Complexes 1/2, 3/4, and 9/10 were used exclusively for rocket and missile testing, and Launch Complexes 14 and 34 also used for manned spaceflight. Launch Complexes 14 and 34 are part of the CCAFS National Historic Landmark District established in 1984.

Launching of Snark missile from Pad 2, March 3, 1960.

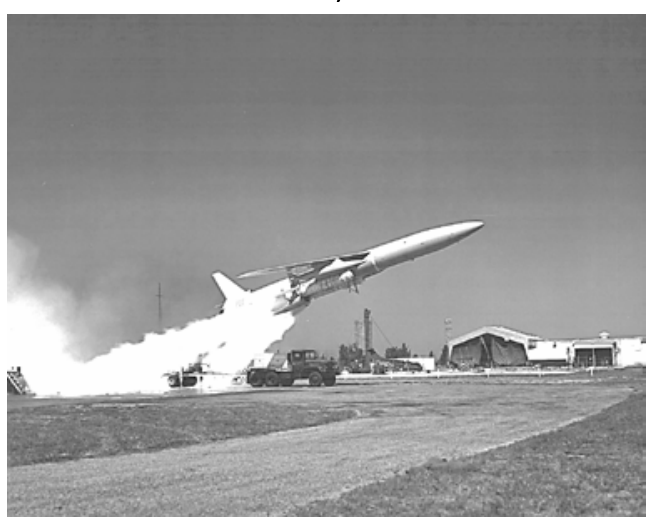


Sunny Adams. 2016. ERDC/CERL TR-16-4. Cultural Landscape Analysis of Existing Historic Districts: Picatinny Arsenal, New Jersey, http://acwc.sdp.sirsi.net/client/en_US/search/asset/1050146

This study documents the cultural landscape at Picatinny Arsenal, focusing on five existing historic districts. This work looks at the historic development and discusses the existing conditions within each of the five districts. It analyzes the features within each district for their historic significance and integrity, and based on this analysis, makes treatment recommendations. This document meets the requirements for Federal agencies to address their cultural resources which are defined as any prehistoric or historic district, site, building, structure, or object. Especially relevant is Section 110 of the National Historic Preservation Act, which requires Federal agencies to inventory and evaluate their cultural resources.

Clint A. Wilson. 2016. ERDC/CERL TR-16-5. Demonstration of A Liquid-Applied Liner System for Corrosion Protection and Rehabilitation of Wastewater System Structures: Final Report on Project F11-AR24, http://acwc.sdp.sirsi.net/client/en_US/search/asset/1049266

Concrete and masonry structures in DoD wastewater collection and treatment systems severely corrode over time. Causes include biologically generated sulfuric acid, and are often related to microbially induced concrete corrosion (MICC). This report describes the demonstration of an emerging technology that uses a silicone-modified polyurea compound and closedcell foam to line deteriorating structures, creating a barrier that is highly resistant to corrosive effluents. At the demonstration site, Fort Bragg, NC, the patented "stress-skin liner" system was applied to one wastewater lift station and 11 manholes. The technology was applied by licensed contractors without problem, and visual inspection by a third-party

Finished (coated) manhole.

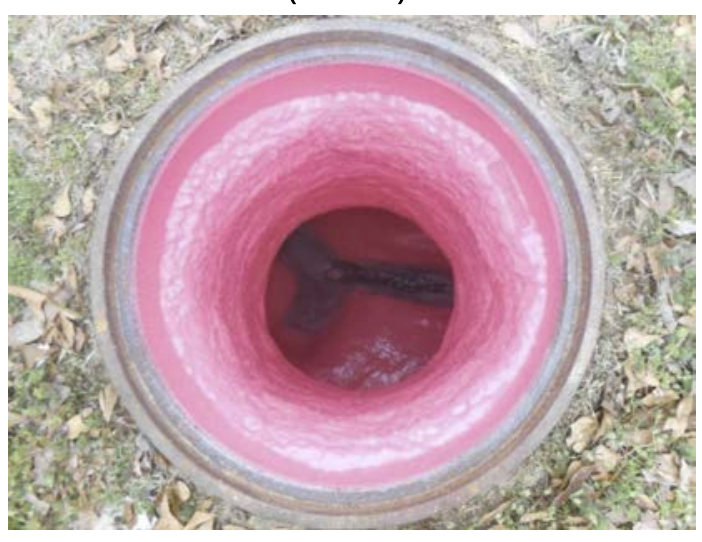


contractor confirmed that the quality and condition of the coatings was good. Because no destructive coating-adhesion testing was permitted inside the structures, concrete and masonry coupons were coated with polyurea and tested twice: once at time zero and once after 12 months. Initial coating adhesion was good, but adhesion after exposure was significantly reduced where coating edges were near to uncoated substrate that was continually wetted by sewage. Coating quality after 12 months was confirmed by visual inspection. The project return on investment (ROI) is 1.00; an alternate ROI calculated without research first costs is 5.5.

Sunny E. Adams. 2016. ERDC/CERL TR-16-8. Character-Defining Features of Contributing Buildings and Structures in the Signal School Campus Historic District at Fort Gordon, Georgia, http://hdl.handle.net/11681/19824

This document is an architectural survey of character-defining features for the contributing features of the Signal School Campus Historic District located at Fort Gordon, GA. This survey satisfies Section 110 of the National Historic Preservation Act of 1966 as amended, and it was used to determine which elements of the buildings and structures of the historic district Concrete waffle ceiling structure that extend out to form an overhang, Bldg. 25810, Brant Hall. are character-defining features for the elements that are eligible for the National Register of Historic Places.

Michael Mclnerney. 2016. ERDC/CERL TR-16-10. Corrosion Control of Central Vehicle Wash Facility Pump Components Using Alternative Alloy Coatings: Final Report on Project F09-AR14, http://acwc.sdp.sirsi.net/client/en_US/search/asset/1050670

Central Vehicle Wash Facilities (CVWFs) at military installations are essential for supporting the readiness of tactical vehicles. Steel washrack pumps are vulnerable to accelerated degradation where supply water is corrosive and infused with fines. Pump failure can occur with little warning, taking the CVWF out of service for unscheduled maintenance. This project tested two advanced coating materials on critical internal pump components to evaluate cost and performance. 
At the Fort Polk, LA, CVWF, inMilitary vehicle being cleaned at CVWF. ternal components of one new pump were coated with a thermally sprayed cobalt alloy, and matching components in another pump were coated chemically with an electroless nickel (EN) material. Both pumps were used for 15 months, then

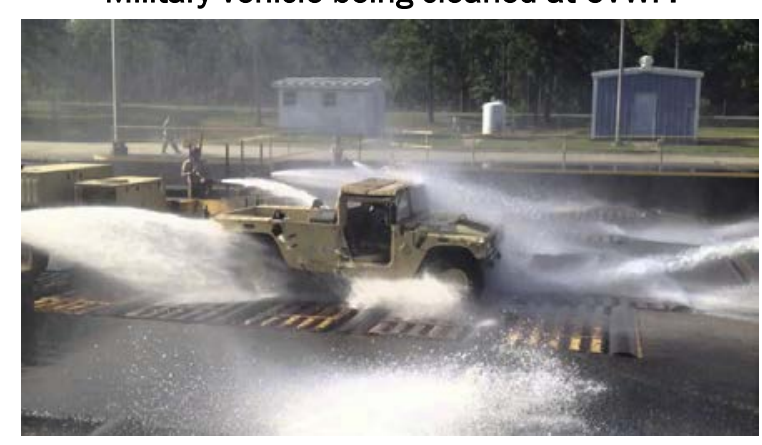
disassembled and inspected. No significant corrosion degradation of pump components was observed on either pump. However, pump components coated using the EN process performed slightly better than those coated using the thermally sprayed alloy. The EN coating produced more uniform results and was less expensive, so it may be preferred by Directorates of Public Works (DPWs). The ROI for the EN coating is 2.59. Both coatings are conservatively estimated to double pump service life when compared with the previous pumps, but the lack of service records precluded a firm, data-driven prediction.

Adam Smith. 2016. ERDC/CERL TR-16-11. Architectural Survey of Laramie Armory, Wyoming Army National Guard, http://acwc.sdp.sirsinet/client/en_US/search/asset/1050847

This document is an architectural survey of the armory that is used by the Wyoming Army National Guard and located in Laramie, WY. The Armory was constructed in 1959, and the Field Maintenance Shop was built in 1961. This survey satisfies Section 110 of the National Historic Preservation Act of 1966 as amended, and it was used to determine the eligibility of this armory for inclusion on the Laramie Armory, showing main entry with bright-aluminum, plate-glass doors with sidelights, transom, and a brick detail wall.

National Register of Historic

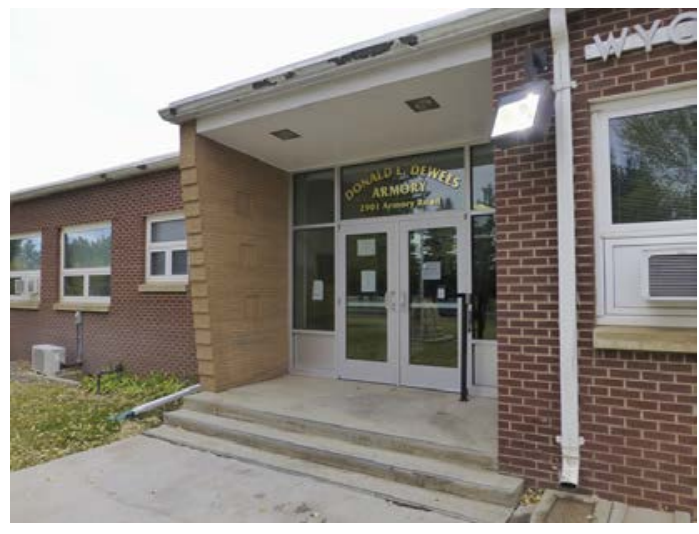
Places (NRHP). This report recommends that the Laramie National Guard Armory is significant under NRHP criteria, and that it retains enough integrity to be individually eligible for the NRHP under Criteria A and C. 
Adam Smith. 2016. ERDC/CERL TR-16-12. NRHP Eligibility of the Fort Huachuca, Arizona, Elevated Water Tank (Facility 49001) and reservoir (Facility 22020), http://acwc.sdp.sirsi.net/client/en_US/search/asset/1050908

This document is an assessment of NRHP eligibility of the Fort Huachuca, AZ, elevated water tank (Facility 49001) erected in 1941 and a reservoir (Facility 22020) constructed in 1959. The elevated water tank (Facility 4901) has remained generally unchanged except for different painting schemes. The demolition and reconstruction of the surrounding World War II temporary buildings makes this portion of the Fort Huachuca cantonment ineligible for the NRHP as a historic district. Although unchanged since its conFort Huachuca, AZ, Elevated Water Tank. struction, the reservoir (Facility 22020) is not significant for construction technology. This survey satisfies Section 110 of the National Historic Preservation Act of 1966 as amended, and was used to determine the eligibility of the elevated water tank under Section 106 of the National Historic Preservation Act of 1966 (NHPA) due to an undertaking, and the eligibility of the reservoir under Section 110 of the NHPA for inclusion on the NRHP. It is the recommendation of this report that the elevated water tank (Facility 49001) is not eligible to the NRHP since it is not individually significant and is not part of a larger historic district. The reservoir (Facility 22020) is individually not significant, and it is not part of a larger historic district.

Natalie R. Myers. 2016. ERDC/CERL TR-16-15. Assessing Socioeconomic Impacts of Cascading Infrastructure Disruptions Using the Capability Approach, http://acwc.sdp.sirsi.net/client/en_US/search/asset/1051046

U.S. Army doctrine requires that commanders understand, visualize, and describe the infrastructure component of the J oint Operating Environment to accomplish the Army's missions of protecting, restoring, and developing infrastructure. The functionality of modern cities relies heavily on interdependent infrastructure systems such as those for water, power, and transportation. Disruptions often propagate within and across physical infrastructure networks and result in catastrophic consequences. The reaction of communities to disasters may further transfer and aggravate the burden and facilitate cascading secondary disruptions. 
Hence, a holistic analysis framework that integrates infrastructure interdependencies and community behaviors is needed to evaluate vulnerability to disruptions and to assess the impact of a disaster. The research for Human-Infrastructure System Assessment (HISA) for Military Operations adopts the Capability Approach (CA) to measure and predict the impact of potential infrastructural interdictions on the City of Maiduguri, Borno State, Nigeria. With the CA, 10 capabilities are identified to describe the wellbeing levels of Maiduguri. To quantify these 10

Capability of having access to electricity.

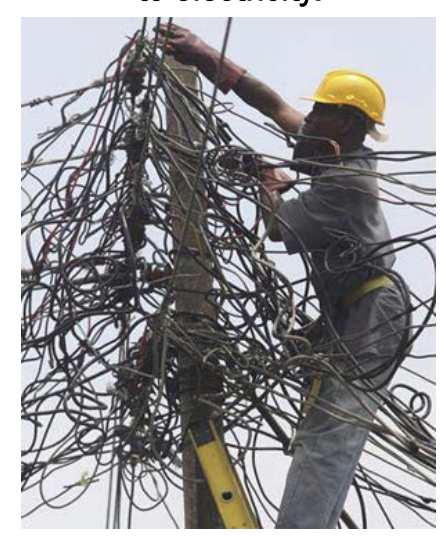
capabilities, 16 indicators were chosen to represent them. These indicator justifications provide the rationale for choosing the indicators for the corresponding capabilities and predictive modeling. Developing probabilistic predictive models of the indicators (or their indices) allows analysis of social well-being in relationship to cascading infrastructure failure.

\section{Adam Smith. 2016. ERDC/CERL TR-16-17. Cultural Landscape Inventory for Picatinny Arsenal, New Jersey, http://acwc.sdp.sirsi.net/client/en_US/search/asset/1051607}

This document presents a historic context, integrity analysis, and evaluation for the NRHP of the installation as a whole for Picatinny Arsenal, NJ . This work is a companion study to ERDC-CERL TR-16-4, which documented the cultural landscapes of the existing five historic districts. The report meets the requirements in NHPA for Federal agencies to address their cultural resources-defined as any prehistoric or historic district, site, building, structure, or object. Identification of potentially significant properties is achieved only through a survey and evaluation to associate a property within a larger historic context.

BIdg. 3250 (deemed eligible for the NRHP).

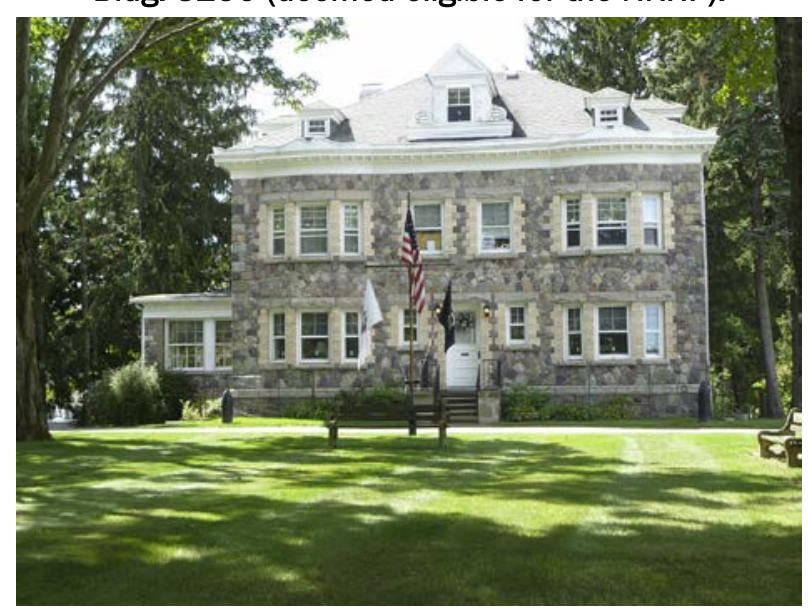


Richard G. Lampo. 2016. ERDC/CERL TR-16-21. Demonstration and Validation of a Composite Grid Reinforcement System for Bridge Decks: Final report on Project F12-AR01, http://acwc.sdp.sirsi.net/client/en_us/search/asset/1054386

The DoD maintains a large array of road networks that include vehicular bridges. Moving people, materials, and equipment is critical to the DoD mission. Many of these bridges are in dire need of major repairs or replacement due to corrosion and material degradation. The application of corrosion-resistant technology can extend the service life of bridges and reduce maintenance costs.

This DoD Corrosion Prevention and Control Program project demonstrated and validated the performance characteristics of the fiber FRP composite, threedimensional Gridform product for reinforcing concrete bridge decks that was designed to solve many of the installation and life cycle problems associated with

Section of the 3-D Gridform reinforcement.

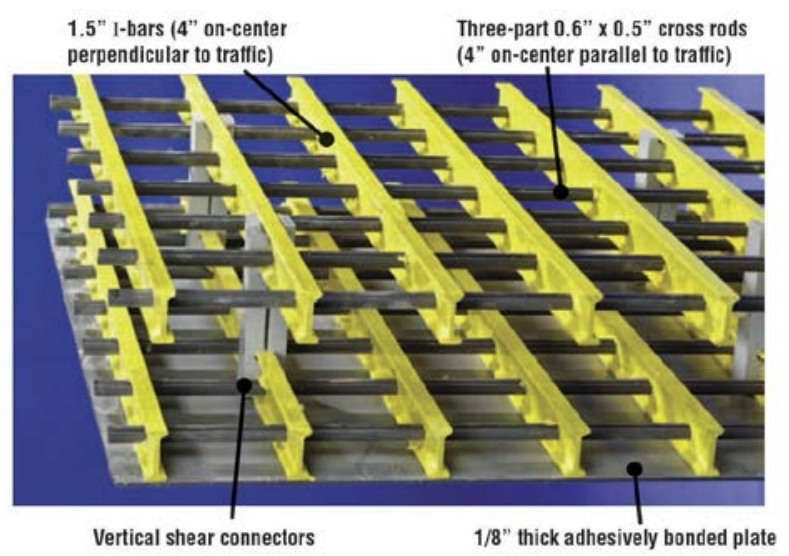
steel-reinforced bridge decks. The Gridform technology replaced the existing steel-reinforced concrete deck on one span of Bridge No. 4 at Fort Knox, KY. The newly replaced span's performance was compared to a second span that was newly replaced with a concrete deck using traditional steel rebar reinforcement. Structural testing and corrosion monitoring and analysis of the bridge was performed. Results show that using Gridform technology could provide needed load capacity and improved corrosion protection for DoD bridges, while maintaining structural capability. The technology's ROI is 10.31 .

Richard G. Lampo. 2016. ERDC/CERL TR-16-22. Demonstration of CorrosionResistant Hybrid Composite Bridge Beams for Structural Applications: Final Report on Project F12-AR15, http://acwc.sdp.sirsi.net/client/en_US/search/asset/1054387

The Army has 1,500 vehicular bridges on its installations that can incur high maintenance costs and even early replacement as a result of corrosion of the steel support structures or the reinforcing bar in the concrete. The application of corrosion-resistant technology can extend the service life of bridges and reduce maintenance costs. 
The Office of the Secretary of Defense Corrosion Prevention and Control Program project demonstrated and validated a corrosion-resistant hybrid composite beam (HCB) for the reconstruction of a one span of a traditional steel and concrete bridge at Fort Knox, KY. The HCBs were installed on half of the bridge, and conventional steel beams were installed on the other half. Structural analysis of the bridge was performed, and the span with HCBs was found to meet all design specifications and load ratings. This technology can increase the life cycle of bridge infrastructure when used in new construction and replacement by the Army and all other Federal agencies. The technology's ROI is 4.22 .

\section{Mark S. Dortch. ERDC/EL CR-16-2. Modeling the Fate of Lead from Small Arms Firing Ranges, Fort Jackson, SC (Distribution F).}

During studies associated with the Army's Operational Range Assessment Program (ORAP), Phase II, measured lead and copper concentrations in water and sediment exceeded the ecological protective action limit (PAL) at the entrance to Boyden Arbor Pond on Gills Creek. Boyden Arbor Pond is within, and adjacent to, the installation boundary of Fort J ackson. There is concern that these metals could become mobile and bioa-

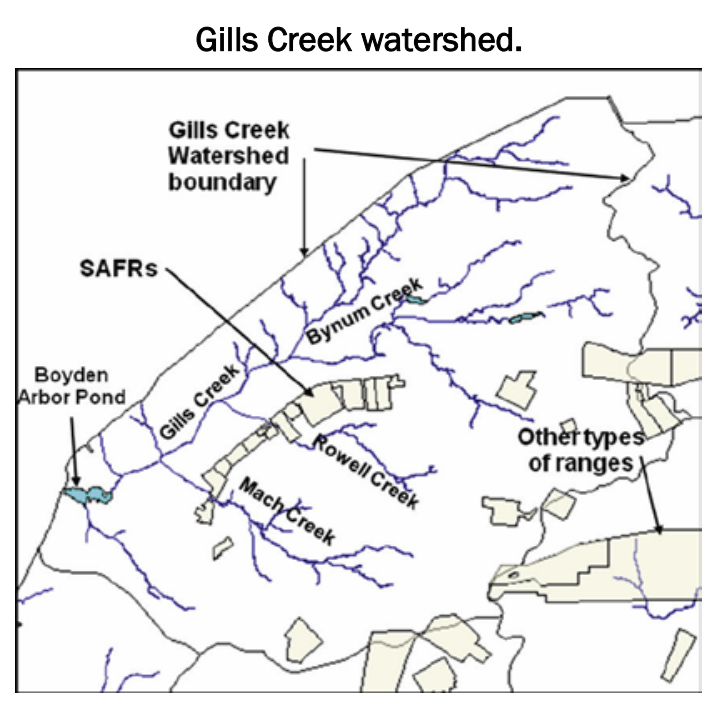
vailable to ecological receptors outside the installation boundary. The Small Arms Firing Ranges (SAFRs) within the Gills Creek watershed are the likely source of these metals. This study was conducted to evaluate the fate of lead residue that is deposited on the Fort J ackson SAFRs and to evaluate potential range management strategies for reducing lead concentrations in Boyden Arbor Pond. The Training Range Environmental Evaluation and Characterization System (TREECS ${ }^{\mathrm{TM}}$ ) (http://el.erdc.usace.army.mil/treecs/) was 
used for this modeling. The model was calibrated against data collected in 2009 and in 2014. Overall, the predicted concentrations for the calibrated model differed from those observed by a factor of 2.3 , with a relative error of $54 \%$ or less. The best management practices evaluations support the theory that contributions of lead from soil interflow to receiving surface water over the next 75 years will be due to range use over the past 75 years, thus presenting a major challenge for development of a management alternative to meet the PAL for the next 75 years.

\section{Donna J. Schell. 2016. ERDC/CERL SR-16-4. The Department of Homeland Security Supplement to the Environmental Assessment and Management (TEAM) Guide.}

The number of environmental laws and regulations has continued to increase in the United States, and such growth makes compliance increasingly difficult. Environmental assessments have become an operationally consistent way to determine compliance with current environmental regulations. In 1984, CERL, now part of the Engineer Research and Development Center, began research that led eventually to the publication of TEAM Guide, based on Federal environmental regulations. This guide now is used by multiple Federal agencies to enhance consistency and accuracy in their environmental audit programs. In FY16, the Department of Homeland Security (DHS), which was already a partner in using the TEAM Guide, wanted a supplemental assessment tool to encapsulate DHS sustainability directives. The resulting manual is this Department of Homeland Security Supplement to The Environmental Assessment and Management (TEAM) Guide.

Natalie Myers. 2016. ERDC TR-16-3. Understanding the Effects of Infrastructure Changes on Subpopulations: Survey of Current Methods, Models, and Tools, http://acwc.sdp.sirsi.net/client/search/asset/1050107

The Army's understanding of infrastructure as an operational variable has been evolving over the past 30 years in response to significant events that range from international conflicts to domestic weather-related disasters. These experiences have combined to drive a significant shift in infrastructure doctrine, which now demands that commanders and staff understand, visualize, and describe the infrastructure variable to accomplish the Army's assigned missions of protecting, restoring, and developing infrastructure, all of which are missions essential to restoring stability after conflict or disaster. 
Current Army doctrine, however, does not say how commanders and staffs are to approach these challenging tasks. This report provides a focused examination of existing infrastructure assessment methods, models, and tools relevant to commanders' and staffs' growing need for $u$ sing a holistic analytical capability regarding infrastructure.

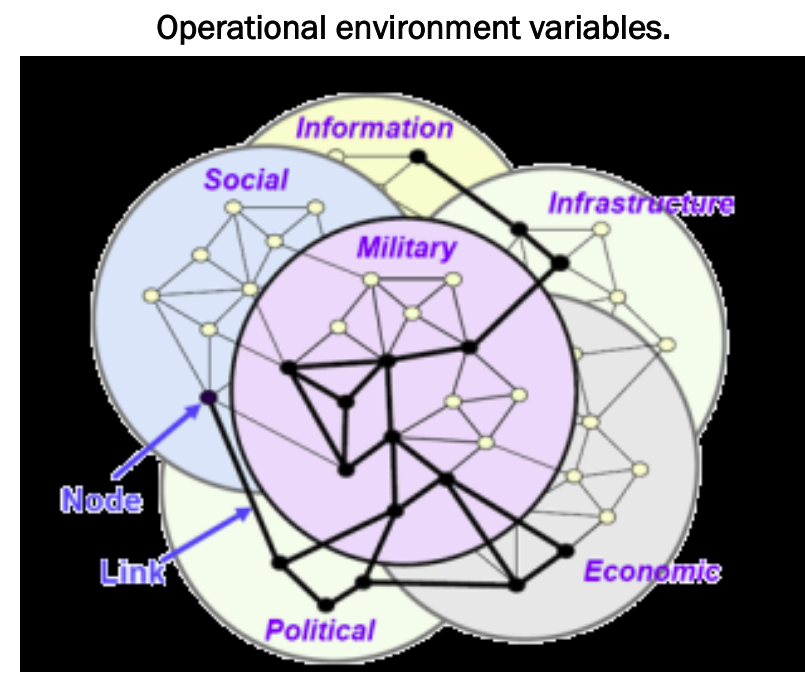

Stephen D. Cosper. Public Works Technical Bulletin (PWTB) 200-1-143. Update of Opportunities for Reducing Construction and Demolition Waste from Residential Communities Initiative (RCI) Programs, http://www.wbdg.org/ccb/ARMYCOE/PWTB/pwtb_200_1_143.pdf

Disposal of construction and demolition (C\&D) debris at Army installations has become problematic in both economic and environmental terms. Installations with Facility Reduction Program requirements, active Military Construction (MILCON) programs, and RCI projects are facing a significant C\&D debris burden. Army-wide, C\&D debris comprises just over half of total waste generation; this figure can be much higher at installations with very active construction programs.

Concrete recycling with onsite crusher.

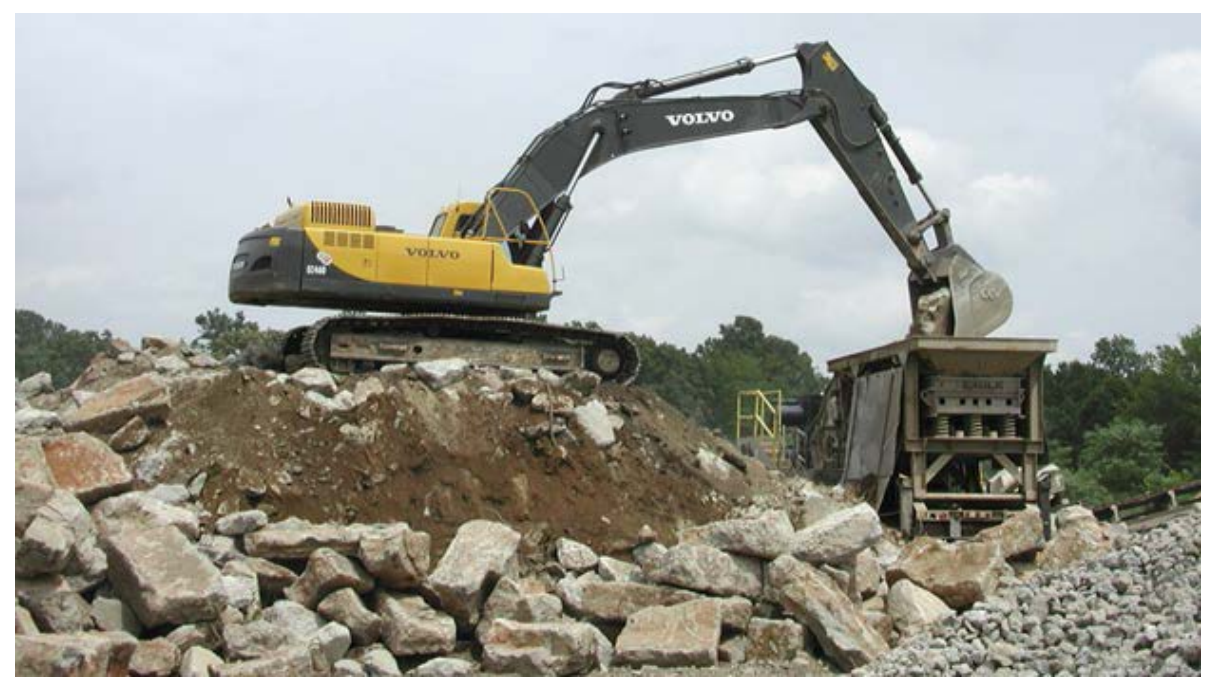


Landfilling C\&D debris also has environmental consequences. The U.S. Environmental Protection Agency (USEPA) has identified C\&D debris as a contributor to GHG emissions. This is just one of a number of concerns such as: the life cycle environmental effects of extracting materials from the earth, the depletion of natural resources, the burden to landfill space, and the manufacture, transport, and disposal of virgin materials in lieu of reusing or recycling existing materials. As an example of the positive environmental impact, on average $75 \%$ of the dimension lumber can be recovered from a wood-framed building (Falk 2002). This PWTB provides updated information for the recovery, reuse, and recycling of building materials that are typically disposed of as demolition waste.

Anne Koster. PWTB 200-1-150. Multinational Analysis of Military Vehicle Impacts and Regulatory Pressures on Training Land Management, http://www.wbdg.org/ccb/ARMYCOE/PWTB/pwtb_200_1_150.pdf

To gain strategic insight into effective and efficient land management practices, this PWTB documents how certain U.S.-allied nations have dealt with challenges related to intensified human development, encroachment, soil conservation, climate change, and ecosystem management on their military training lands. The opportunities identified and lessons learned are presented to enable the U.S. Army to save money, optimize co-land utilization, and preserve training land resources over the long term. Innovative technologies may have been developed in other countries to deal with more stringent regulations, and this project reviews applicable foreign solutions, identifies solutions for use within the U.S. Army, and projects potential up-and-coming regulatory pressures (e.g., proposed new Threatened and Endangered Species [TES] listings). The knowledge gained from this effort may bolster stewardship, enhance land rehabilitation, and promote military training sustainment.

Anne Koster. PWTB 200-1-148. Creative Strategies and Opportunities for Managing Cultural Resources on Army Training Lands, http://www.wbdg.org/ccb/ARMYCOE/PWTB/pwtb_200_1_148.pdf

DoD installations have a responsibility to maintain stewardship of the cultural resources on lands they own or manage. Of all the military service branches, the U.S. Army holds the largest inventory in major categories of land and cultural/ historic resources. These historic and cultural resources are assets to the Nation's heritage, but can also be considered assets to the training mission of Army installations within the continental United States (CONUS). Because of the high national and military asset value of cultural 
resources to the Army, installation management strategies for cultural resources are important to the management approach taken within installation cantonment areas as well as on training ranges. This PWTB identifies creative and innovative technologies and BMPs for cultural resources and site management on Army training lands. To facilitate sharing of BMPs, this publication details known examples from actual projects. In addition to the benefit of information sharing, cost savings and increased land availability also will result from efficient integration of cultural resource management with site and training area land management BMPs described in this PWTB.

At Defence Training Estate (DTE) Otterburn and DTE Salisbury Plain (UK), grazing is a land management practice for vegetative cover maintenance.

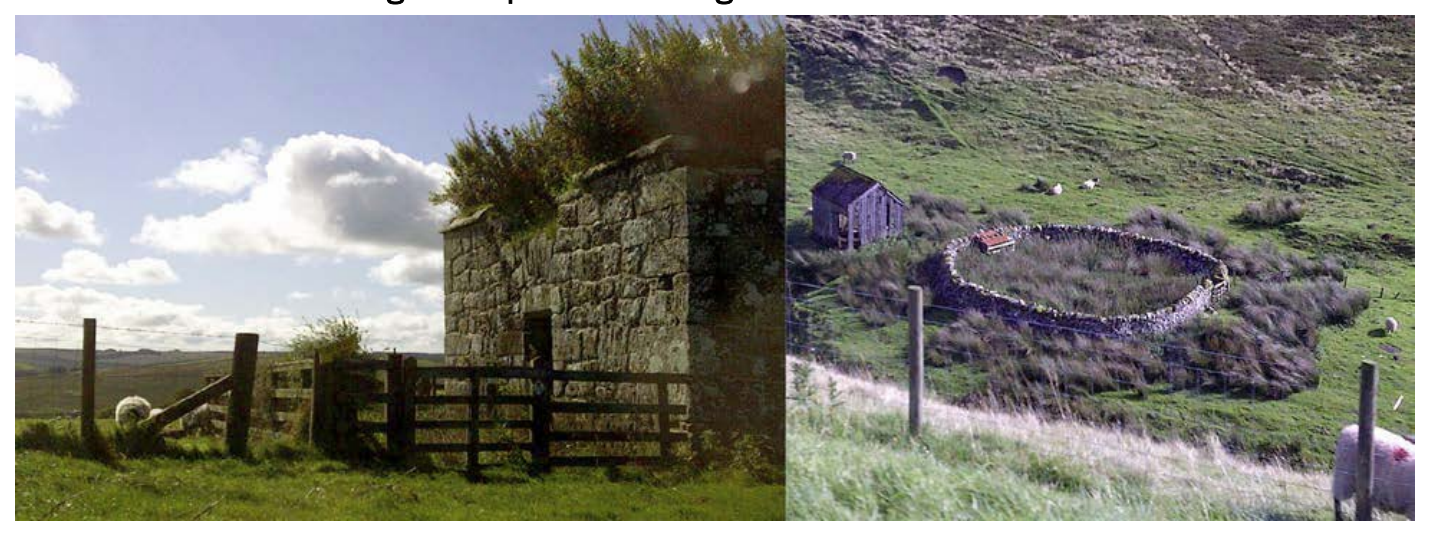

Richard G. Lampo. ERDC/CERL TR-15-29. [FO9-ARO2] Demonstration and Validation of Materials for Corrosion-Resistant Fencing and Guard Railings in Aggressive Climates, http://acwc.sdp.sirsi.net/client/en_U.S./search/asset/1046352

Standard galvanized-steel chain-link fencing, including products coated with polyvinyl chloride (PVC), can severely corrode in as little as 5 years in coastal locations where the atmosphere is warm, humid, and infused with chlorides. This problem affects fencing needed to secure military equipment, supplies, and buildings. Painted and galvanized-steel safety railings also can severely corrode in those environments, creating personal-safety hazards. This study assessed several alternative corrosion-resistant materials for fencing and railings using atmospheric exposure coupons and fullscale installations. The research design compares the performance of the alternative and conventional materials to identify those that may reduce the Army's corrosion prevention and control costs, including fuse-bonded PVC, galvanized-steel, stainless steel, aluminized steel, a proprietary material called Galfan ${ }^{\circledR}$, aluminum alloys, and FRP composites. The test exposure sites were Kahuku, HI; Duck, NC; and Treat Island, ME. 
Michael J. White. PWTB 200-1-140. Terrain and The Physical Environment: Factors for Noise Mitigation, http://www.wbdg.org/ccb/ARMYCOE/PWTB/pwtb_200_1_140.pdf

Army training involves live-fire and ordnance activities that generate highamplitude sound and potential restrictions on training areas. Army installations are faced with new requirements and must rapidly adapt to control noise without impacting mission. In addition, high-amplitude sound can pose risks to soldier health, disturb wildlife, and provoke civil affairs issues with surrounding communities.

This PWTB offers assistance with these challenges by explaining both the physical effects of terrain on sound propagation and the use of digital terrain maps when preparing noise assessments. With the increasing availability of digital terrain maps, it is now possible to consider the role of terrain when preparing noise contours for military installations with live-fire training and demolition activities. It is difficult, however, to anticipate whether the terrain in the vicinity of an installation will be of benefit for noise shielding, and whether attention given to the question will change the noise assessment. This PWTB helps to overcome this assessment dilemma by outlining steps to using terrain maps with noise analyses software. The information in this PWTB is primarily for the GIS specialist who may be tasked with preparing such an assessment. However, the material also provides general guidance on how to interpret noise contours that may be useful to urban planners, land managers, and others interested in knowing more about training range noise.

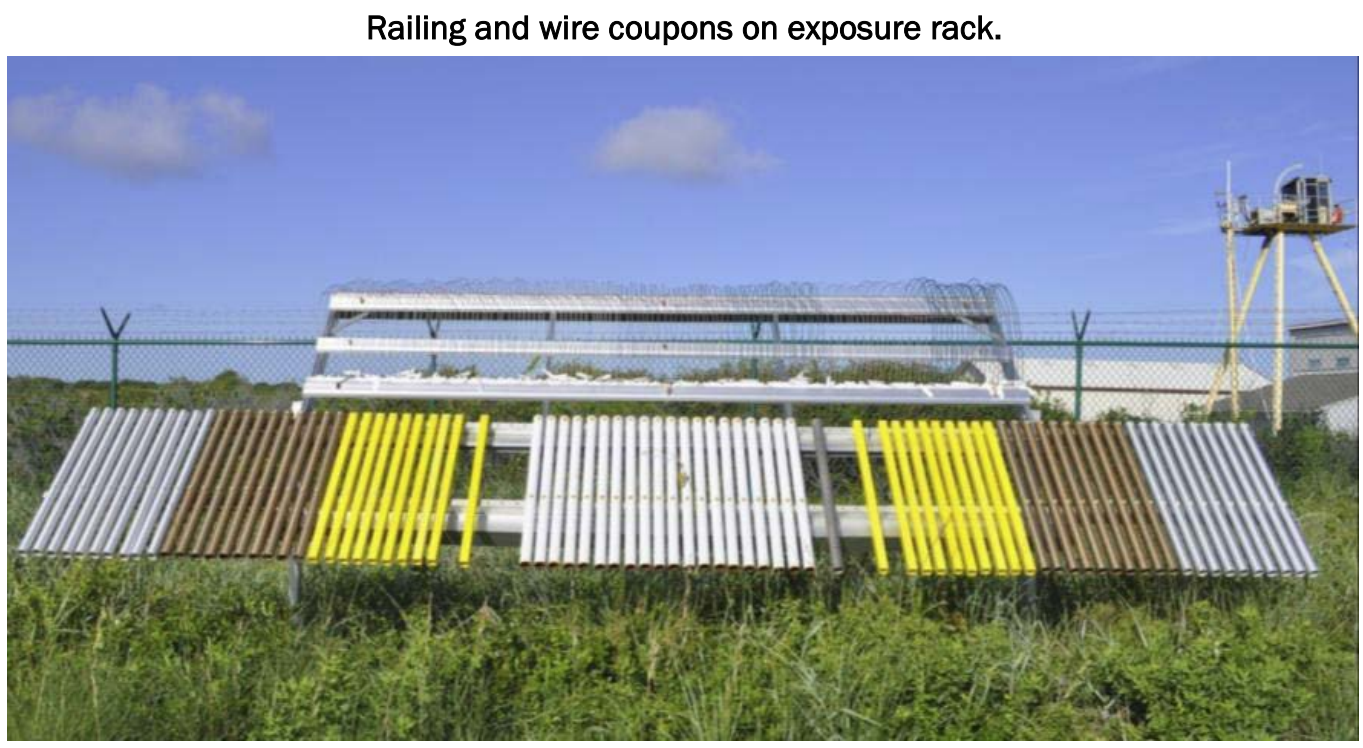


Dongsheng Mao, Igor Pavlovsky, Richard L. Fink, et al. ERDC/CERL TR-15-6. Multifunctional Nanocomposites for Improved Sustainability and Protection of Facilities, http://acwc.sdp.sirsinet/client/en_U.S./search/asset/1043506 ERDC/CERLTR-15-6

The U.S. Army makes worldwide use of high-performance ballistic resistant fiberglass composite panels for force protection and other applications. This widespread use creates a need for an improved panel material that offers better bullet resistance at a lighter weight while still meeting existing ballistic resistance standards. This work to solve the Army's need included conceiving, developing, and validating a new nanocomposite material that is made of epoxy resin blended with functionalized carbon nanotubes (CNTs) that exhibits highly improved flexural strength and electrical conductivity for improving ballistic resistance in lighter weight GFRP ballistic panels. In
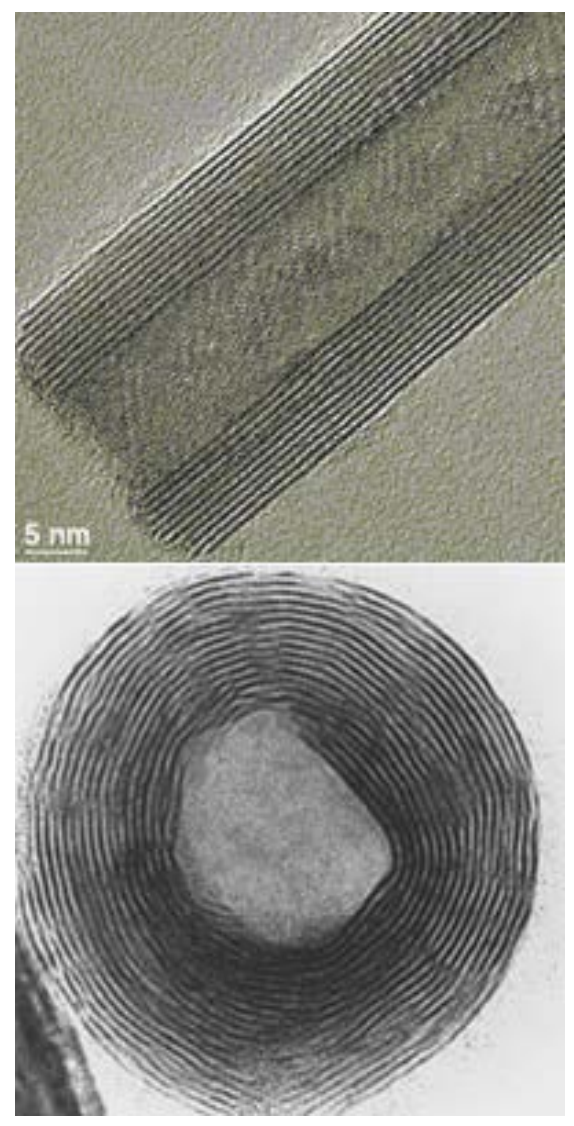

The unique structure of tungsten disulfide nanotubes make them remarkably strong and durable. addition, this work tested various options for adding self-healing, CNT reinforcement, Electromagnetic Interference shielding, and self-decontaminating properties for GFRP panels. Results of separate studies included in this report are: loading panels with CNTs by using different mass fractions and functionalization methods; introducing a self-healing agent directly to the matrix or contained in embedded hollow glass fibers; using layers of proprietary CNT sheeting in the GFRP composite; testing the electromagnetic impulse shielding effects of introducing conductive materials; and adding a biocide-containing coating to finished panels. 
Alfred D. Beitelman and Susan A. Drozdz. ERDC/CERL TR-15-12. [F10-AR01] Corrosion-Resistant Coatings for Air-Conditioning Coils and Fans, http://acwc.sdp.sirsi.net/client/en_U.S./search/asset/1043986

DoD military installations operate air-conditioning equipment in humid and coastal locations that produce high levels of corrosion. Installation experience has shown that severe corrosion has reduced expected equipment life cycles by up to $50 \%$. This project for the Office of the Secretary of Defense Corrosion Prevention and Control Program demonstrated and evaluated the performance characteristics of two corrosion prevention coatings on condenser coils in highly corrosive environments. This work assessed the capabilities and advantages of an aluminum-impregnated polyurethane coating and a flexible epoxy polymer applied to two separate condenser units at Schofield Barracks, HI. The work also included fabricating and exposing test coupons of various substrates, each coated with the two coating systems and a third coating commonly used in lessFacility 55384, Boresight Tower - AN/FPS 16 Radar.

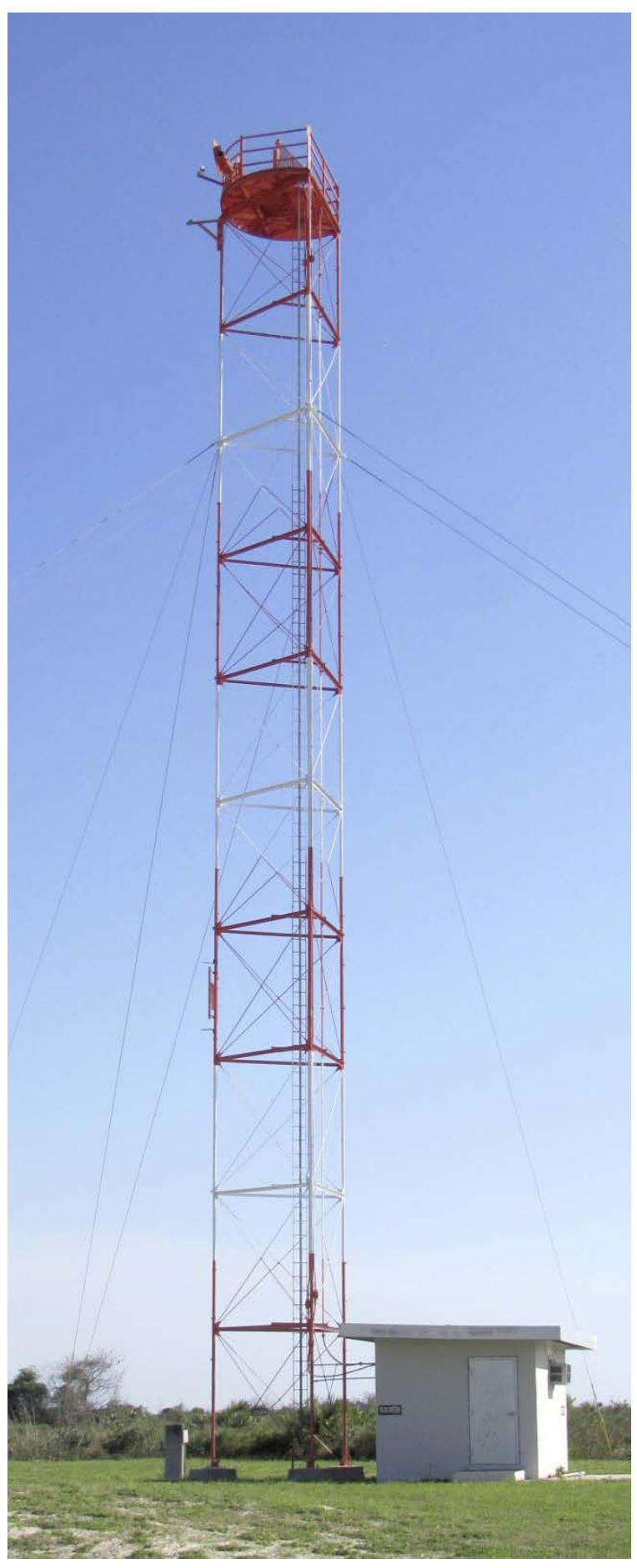
corrosive environments. 
These coupons were exposed both at the Schofield Barracks site and in a laboratory-accelerated exposure cabinet. The work recommends that copper rather than aluminum components be specified in air conditioners operating in highly corrosive environments. A copper substrate protected with a newer type of corrosion coating is projected to extend the equipment's expected life cycle from 7- 10 years to $25-30$ years. The return on investment for the project is 3.89 .

\section{Susan I. Enscore and Julie L. Webster. ERDC/CERL TR-15-34. Inventory and Evaluation of Buildings in the Industrial Area, Cape Canaveral Air Force Station, http://hdl.handle.net/11681/19993}

This report inventories all of the buildings and structures constructed at the Industrial Area, Cape Canaveral Air Force Station, FL, between the years of 1951 and 1968, not previously documented by the installation. Determinations of eligibility to the NRHP are then made based on the significance of the buildings and the degree to which they retain their physical integrity for conveying that significance. It was determined that 19 of the 85 buildings or structures inventoried and evaluated for this study were eligible for inclusion in the NRHP individually (two facilities) or as part of a historic district related to missile testing, missile assembly, and man in space significance themes. The period of significance for these buildings and structures is the Cold War Era, dating from 1951- 1991. It was determined that 66 facilities are considered not individually eligible and noncontributing to the historic district due to either lack of significance or lack of integrity.

A further 15 previously surveyed buildings were evaluated for inclusion in a proposed Cape Canaveral Air Force Station Industrial Area Historic District (CCAFSIAHD). Of these properties, four buildings were previously determined eligible individually for inclusion in the NRHP. This survey recommends their inclusion in the proposed CCAFSIAHD, along with five other previously surveyed facilities that have now been determined to be contributing properties. Thus, a total of 27 facilities are recommended to be included in the CCAFSIAHD. Additionally, there is one facility determined individually eligible but outside the historic district. 
Adam D. Smith and Megan W. Tooker. ERDC/CERL TR-15-31. The Army and the FHWA Program Comment for Common, Post-1945 Concrete and Steel Bridges, http://hdl.handle.net/11681/20004

This document presents an analysis of the applicability of the Advisory Council on Historic Preservation's Program Comment for Common Post-1945 Concrete and Steel Bridges with the Federal Highway Administration in regards to Army-owned bridges. The Program Comment eliminates "individual historic Fort Knox Bridge 44. review requirements under Section 106 of the National Historic Preservation Act for common post1945 concrete and steel bridges and culverts" for the FHWA in certain cases. The Program Comment can be used for post- 1945 bridges owned by other federal agencies under certain circumstances. It was the determination of the authors of this report that the Army would gain no significant benefit by utilizing the existing Program Comment for Common Post-1945 Concrete and Steel Bridges, but it may benefit the Army to request a program comment of its own from the Advisory Council on Historic Preservation to cover post- 1945 concrete, steel, and wood bridges.

\section{Smith. 2015. ERDC/CERL TR-15-38. Architectural Survey of Ohio Army National Guard Properties: Volume I - Main Report, http://hdl.handle.net/11681/19977}

This document is Volume 1 of a two-volume architectural survey of 85 buildings and structures used by the Ohio Army National Guard and located across the state of Ohio. The majority of these structures were constructed between 1920 and 1968, with others constructed from 1969 to 1988. This survey satisfies Section 110 of the National Historic Preservation Act of 1966 as amended, and was used to determine the eligibility of these buildings and structures for inclusion on the NRHP. It is the recommendation of this report that 14 armories are significant under NRHP criteria and that they retain enough integrity to be individually eligible for the NRHP. Volume II of this report is published separately and contains the architectural survey forms. 
This document presents an analysis of the applicability of the Advisory Council on Historic Preservation's Program Comment for Common Post-1945 Concrete and Steel Bridges with the Federal Highway Fort Knox, KY Bridge 04 in 2013.

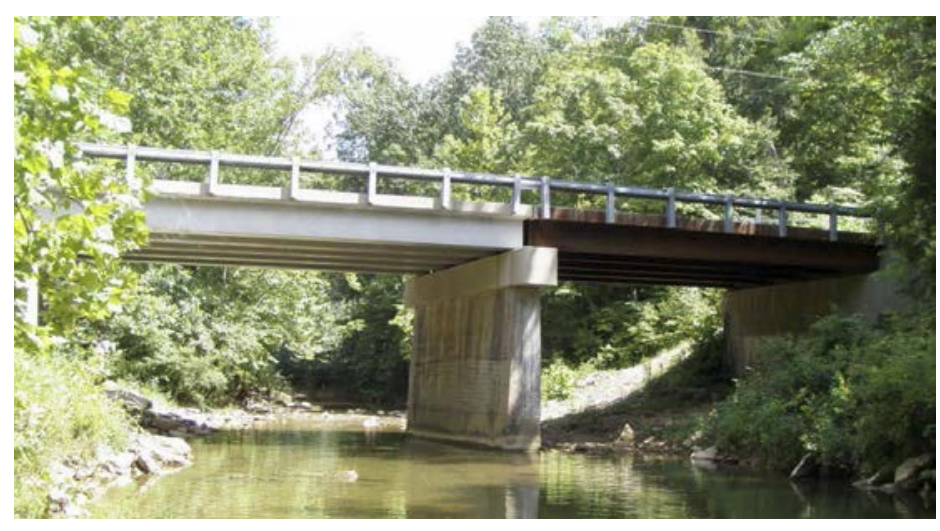
Administration in regards to Army-owned bridges. The Program Comment eliminates "individual historic review requirements under Section 106 of the National Historic Preservation Act for common post-1945 concrete and steel bridges and culverts" for the Federal Highway Administration (FHWA) in certain cases. The Program Comment can be used for post- 1945 bridges owned by other Federal agencies under certain circumstances. It was the determination of the authors of this report that the Army would gain no significant benefit by using the existing Program Comment for Common Post1945 Concrete and Steel Bridges, but it may benefit the Army to request a Program Comment of its own from the Advisory Council on Historic Preservation to cover post-1945 concrete, steel, and wood bridges.

Susan I. Enscore, Adam D. Smith, and Megan W. Tooker. ERDC/CERL TR-1525. Camp Sherman, Ohio: History of a World War I Training Camp, http://acwc.sdp.sirsinet/client/en_US/search/asset/1047630

This document presents a historic context, integrity analysis, and evaluation for the NRHP of the World War I era rifle range at the Camp Sherman J oint Training Center, $\mathrm{OH}$. The report meets the requirements in the NHPA for Federal agencies to address their cultural resources-defined as any prehistoric or historic district, site, building, structure, or object. Identification of potentially significant properties is achieved only through a survey and evaluation to associate a property within a larger historic context. The Camp Sherman Rifle Range was constructed in 1917 for training soldiers in preparation for deployment to European battlefields. This function only lasted until the 1918 Armistice, but the range has been used by the Ohio Army National Guard for training over the decades since. It is the recommendation of this current survey that the 452-acre Camp Sherman Rifle Range (Camp Sherman J oint Training Center) be recommended not eligible to the NRHP due to a significant loss of integrity. 
Adam D. Smith. 2016. ERDC/CERL TR-16-4. Cultural Landscape Analysis of Existing Historic Districts: Picatinny Arsenal, New Jersey, http://hdl.handle.net/11681/20205

This study documents the cultural landscape at Picatinny Arsenal, focusing on five existing historic districts. This work looks at the historic development and discusses the existing conditions within each of the five districts. It analyzes the features within each district for their historic significance and integrity, and based on this analysis, makes treatment recommendations. This document meets the requirements for Federal agencies to address their cultural resources that are defined as any prehistoric or historic district, site, building, structure, or object. Especially relevant is Section 110 of the NHPA, which requires Federal agencies to inventory and evaluate their cultural resources.

Adam D. Smith. 2015. ERDC/CERL TR-15-37. Architectural Survey at Joint Base Langley-Eustis of Fort Eustis Buildings and Structures Built 1946-1975: Volume l, http://hdl.handle.net/11681/19878

This document is Volume I of the two-volume report of an architectural survey of 125 buildings and structures located at J oint Base Langley-Eustis (Eustis), VA, constructed from 1946- 1975, for eligibility to the National Register of Historic Places (NRHP). There were 67 additional buildings and structures on the original list that were covered under other agreements or processes. This survey satisfies Section 110 of the National Historic Preservation Act of 1966 as amended, and it was used to determine the eligibility of these buildings and structures for inclusion on the NRHP. It is recommended that, based on this work's survey, only Bldg. 415 (Landship Training Facility) is significant and retains enough integrity to be individually eligible for the NRHP.

Matthew Bigl and Elias Deeb. 2015. ERDC/CRREL TN-15-2. Site Assessment and Feasibility of a New Operations Base on the Greenland Ice Sheet: Addendum to the Preliminary Report, http://acwc.sdp.sirsi.net/client/search/asset/1047386

The New York Air National Guard (NYANG) 109th Airlift Wing training facility located at Raven in southwest Greenland experienced surface crevassing during the 2012 extreme Greenland melt event, which limited the use of the runway. Because of subsequent interest in relocating the runway, this study analyzed the runway's climatic, physical, and logistical factors, expanding on Site Assessment and Feasibility of a New Operations Base on the Greenland Ice Sheet by Burzynski et al. (2013). Their report 
identified a primary target region for relocating the runway based on stakeholder criteria and climatic data collected from across Greenland. This work improved on this investigation by replacing the proxy (e.g., elevation) previously used for melt with newly released satellite estimates of melt. These new data used changes in microwave emissions from the surface and near surface of the Greenland Ice Sheet to estimate melt days across Greenland. By applying the Burzynski et al. (2013) criteria to the new melt data, melt days/ year were quantified over the past 35 years. This improves the selection criteria for an appropriate relocation zone for the Raven runway, and the ArcGIS framework developed by this project provides the ability to incorporate future stakeholder needs into the site selection analysis.

Rosa T. Affleck, Jeanne M. Roningen, Jennifer S. Macpherson, et al. 2015. ERDC TR 15-10. Analysis of Operational Data: A Proof-of Concept for Assessment of Electrical Infrastructure Impact, http://acwc.sdp.sirsi.net/client/en_U.S./search/asset/1047529

Infrastructure variables required for a community or society to function include basic facilities, services, and installations; and these variables can impact many aspects of daily life. The structure and functionality of the electrical grid in an operating area can affect multiple operational variables. Other infrastructure sectors that rely on the electrical grid can fail The change in standardized radiance between the early morning
prior to and following the blackout. Red areas indicate increase
radiance, and blue areas indicate decreased radiance. when electricity is disrupted. Thus, the impact of electricity in a society is vital for prosperity and security and expands the broad impact on economic and social well-being.

This study used remote-sensing data to examine the electrical system and power-grid functionality for Dhaka, Bangladesh. The focus of this work was on the transmission and distribution networks, the network patterns, and the electrical capacity. In addition, the pattern of a power outage (i.e., 
the 1 November 2014 blackout) and the duration of the outage were used to assess the affected neighborhood and the power-production disruptions at other major power stations within the country. When the Visible Infrared Imaging Radiometer Suite (VIIRS) data were combined with the panchromatic sharpening of WorldView- 2 imagery, it became possible to focus on the affected areas, thereby narrowing the search for electrical-grid components. This study is an example for understanding the dynamic physical environment relevant to military operations.

\section{Victor F. Medina. ERDC WQTN-MS-9. Evaluation of Environmentally Acceptable Lubricants (EALs) for Dams Managed by the U.S. Army Corps of Engineers, http://acwc.sdp.sirsi.net/client/en_US/search/asset/1045297}

This technical note reports on a study undertaken to provide a preliminary assessment of EALs for application in dams managed by USACE. The assessment explores the environmental aspects of these lubricants and also discusses their operational characteristics. The assessment was done primarily through the literature available on this topic, and includes interviews with various experts.

Pintle gate bearing (from the Rock Island Dam, Rock Island, IL) and a self-lubricating bushing from the Dalles Dam, which spans the Columbia River between Washington state and Oregon.
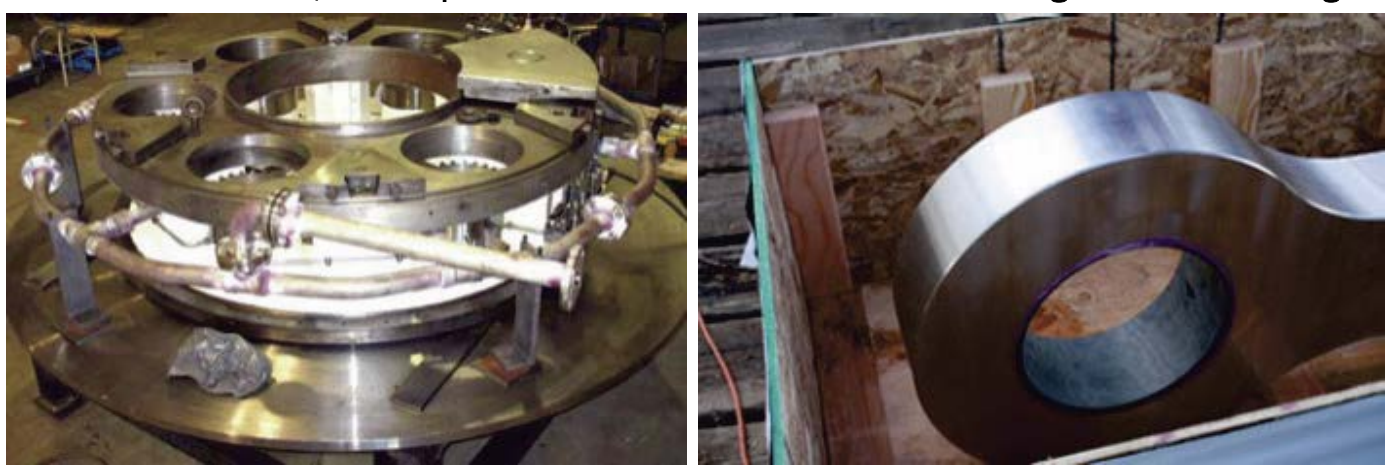

Kevin Bjella. 2015. ERDC/CRREL TR-15-13. Geotechnical Study, Next Generation lonosonde (NEXION) Installation, Thule Air Base, Greenland, http://acwc.sdp.sirsi.net/client/search/asset/1045949

This report presents the results of a geotechnical and structural design for the transmitter antenna of the NEXION at Thule Air Base, Greenland, for the Space and Missile Systems Center, Remote-Sensing Space Environmental Branch, and Air Force Weather. NEXION is a commercial-off-theshelf ionospheric sounder used to measure the electron density of ionospheric plasma. The design required special considerations for installation, construction, and shipment due to the ice-rich permafrost soil conditions at Thule Air Base's remote and logistically difficult location. 


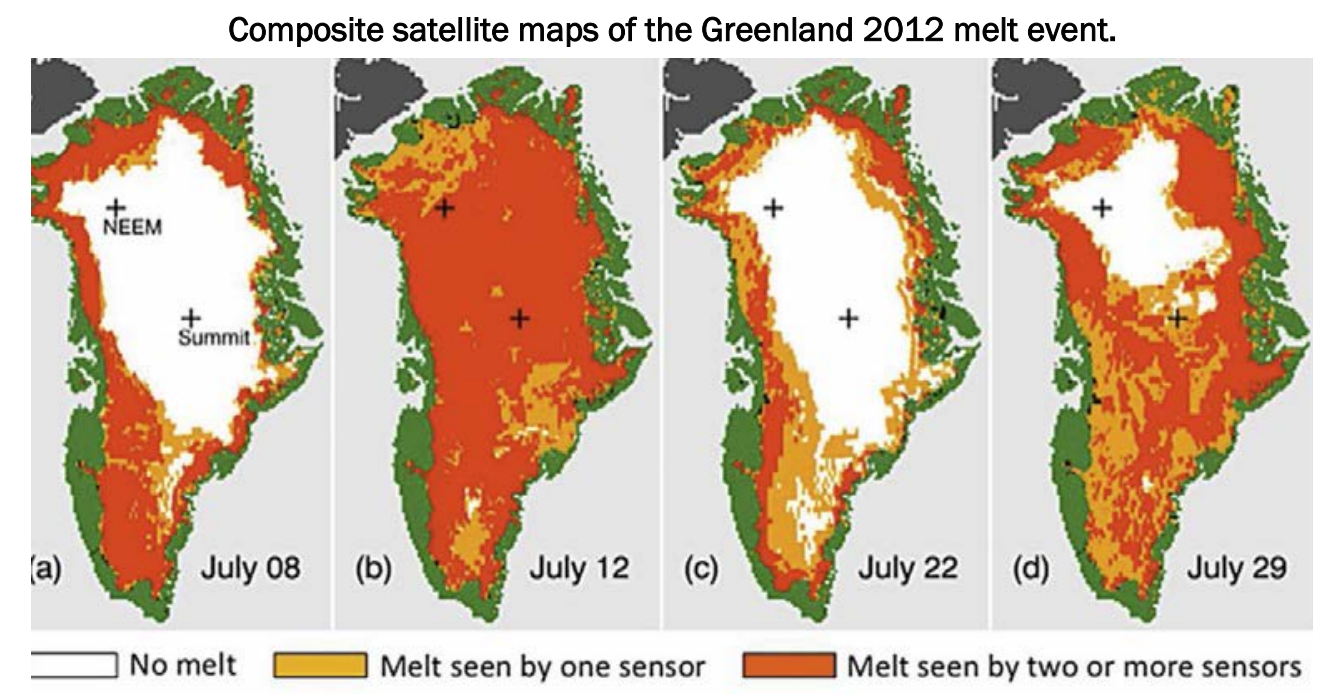

In particular, anchored tension ground connections could not withstand viscoelastic creep of ground ice under extreme wind-loading events. In addition, predicted future climate change required additional considerations to protect the thermal regime of the thaw-unstable sediments.

Recommendations include excavation into permafrost soils, non-frost-susceptible structural replacement fill, and extruded polystyrene board-type insulation to facilitate maintaining and improving the subsurface thermal regime and to provide favorable foundation performance for the NEXION tower system. Furthermore, given the remote site location and limited availability of onsite concreting capabilities, foundations require pre-casting and shipping via ocean transport vessel to Greenland. As such, an alternative foundation detail was designed, including anchor rods, to mitigate the potential for irreparable damage that may occur during shipping and transporting.

Steven F. Daly, Robert Haehnel, and Christopher Hiemstra. 2015. ERDC/CRREL TR-15-2. Vertical Temperature Simulation of Pegasus Runway, McMurdo Station, Antarctica, http://acwc.sdp.sirsi.net/client/search/asset/1041462

Pegasus Runway, located $13 \mathrm{~km}$ south of McMurdo Station, Antarctica, on the McMurdo Ice Shelf (MIS), is constructed out of snow and ice. It is susceptible to weakening and damage caused by melting and to reduction in the strength caused by warm weather and sunlight. This report describes the development of the Pegasus Runway temperature model. It begins by quantitatively describing the physical properties of the Pegasus Runway snow and ice and the physical properties of the MIS directly beneath the runway. 
The temperature model is based on a one-dimensional heat conduction model that includes the penetration and absorption of solar radiation beneath the surface. The report describes the methods for estimating the sensible heat, latent heat, shortwave radiation, and long-wave radiation surface heat fluxes that drive the model and presents estimates of the constant-temperature lower-boundary condition for the model. A novel approach for estimating the initial vertical temperature profile is used. This work simulated the Pegasus Runway temperatures for three austral summer seasons

View of the trench used for installing temperature sensors in the runway.

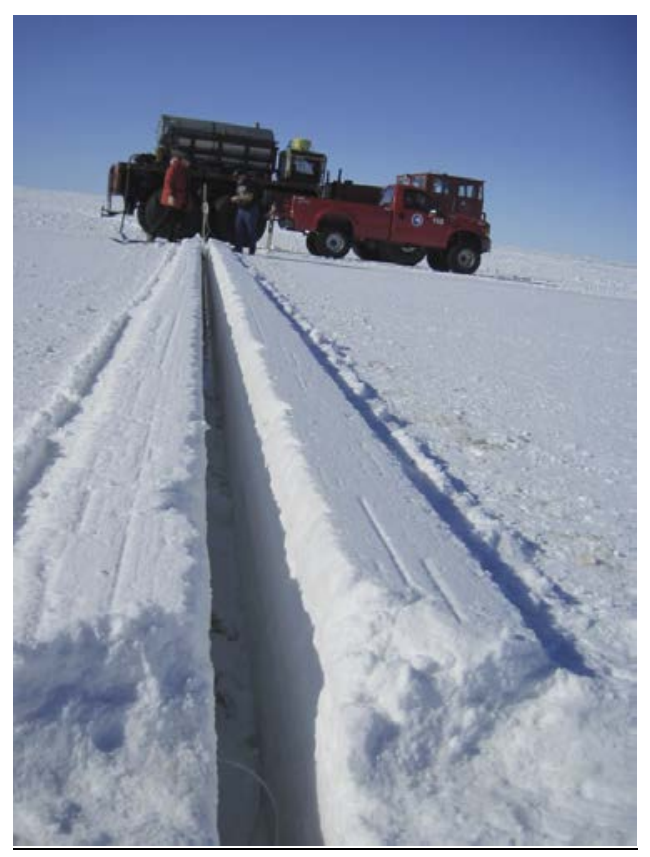
(2011- 12, 2012-13, and 2013-14). The model simulation shows good results when compared to in situ observations of the runway temperatures.

Lynette Barna, Zoe Courville, John Rand, et al. 2015. ERDC/CRREL TR-15-9. Remediation of Old South Pole Station: Phase l: Ground-Penetrating-Radar Surveys, http://acwc.sdp.sirsi.net/client/en_U.S./search/asset/1044471

Old South Pole Station was built between 1956 and 1957 to support the International Geophysical Year. At the time, the buildings composing the main station complex were built on the snow surface, but the increasing depth of snow overcame the structures. In an effort to displace the deepening snow and resulting snow loads, wooden structures called "top hats" were built on top of the roofs of the original buildings. These buried buildings and additional top hat structures created dangerous subsurface voids and then further acted to weaken overlying snow layers.
Amundsen-Scott South Pole Station entrance in 1970 , completely buried by accumulated and drifted snow.

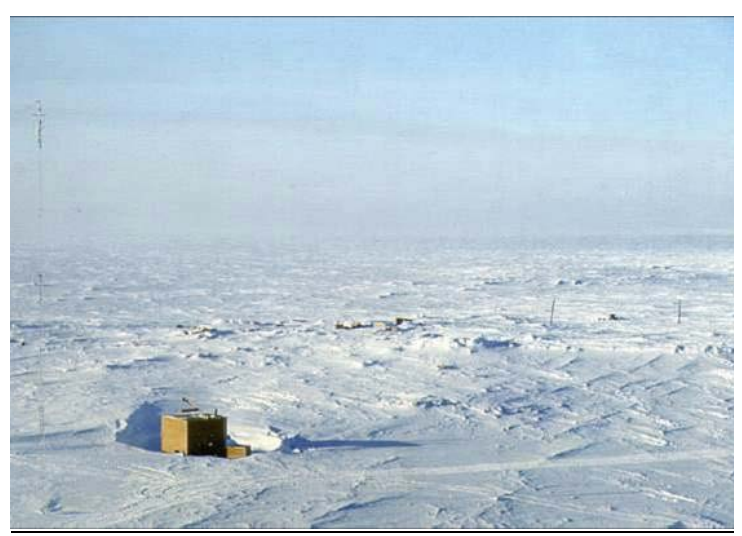


This work therefore conducted GPR surveys at the Old South Pole Station site to identify buried buildings and potential hazards. The GPR survey included techniques used in crevasse detection to identify the locations and dimensions of the buildings. GPR located several top hat roofs as shallow as $14 \mathrm{ft}$ below the snow grade with the roofs of the station buildings $30 \mathrm{ft}$ below the surface at the time of the survey. As a result of this study, GPR located nine buildings within the Main Complex, which were then imploded using blasting. This report describes the methods used to identify the buried buildings and reviews the blasting operations.

Lynette Barna, James Lever, and Allan Delaney. 2015. ERDC/CRREL TR-1510. Remediation of Old South Pole Station Using Autonomous Data Collection and Remote Assessment of Ground-Penetrating Radar, http://acwc.sdp.sirsi.net/client/search/asset/1044472

This report describes a GPR survey assessing the effectiveness of blasting subsurface hazards at the original South Pole Station. Hidden under layers of accumulated snow, false attic structures ("top hats") were built on top of the original buildings to displace the increasing snow depth. By causing an alteration in the snow structure through enhanced metamorphism, the presence of these structures and heat from the buildings reduced the bearing capacity of the overlying snow to support surface-based heavy vehicle.

Blasting was effective in mitigating the subsurface safety risks posed to personnel and equipment operating in the area. The resulting blast crater naturally filled with drift snow. An autonomous polar rover was deployed and successfully conducted a post-blast GPR survey operating at ambient temperatures of $-22{ }^{\circ} \mathrm{F}$ or lower. Expert review of the GPR data confirmed that the targeted structures within the crater were effectively demolished. Data collected by the rover revealed two sites beyond
In Area 2, excavation exposed the supporting members (believed to be the ceiling-floor between the second and third floor levels) of Bldg. A15, an aluminum-framed square structure.

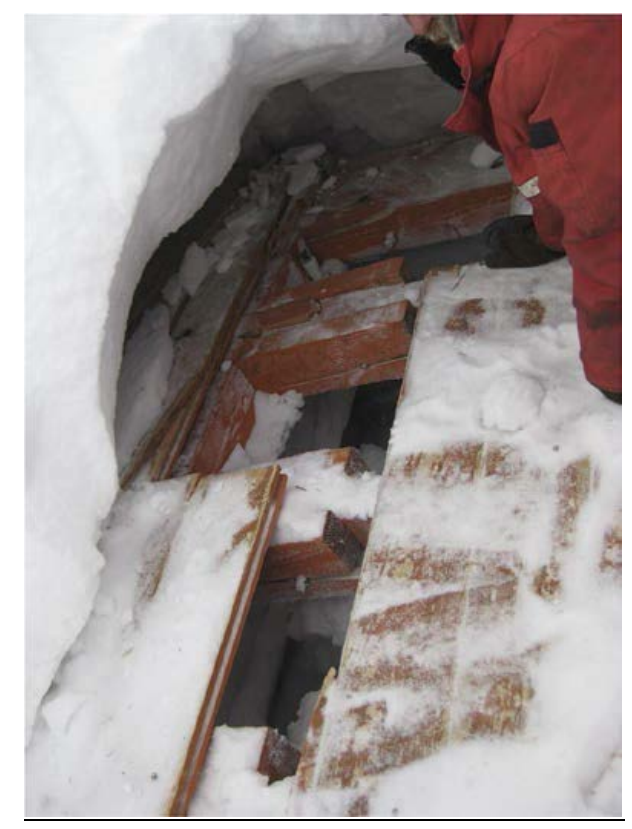


the crater perimeter, within the survey area, that posed a risk to heavy vehicles. A mitigation effort included these two areas. Data collection with an autonomous rover and offsite expert data review proved to be effective tools for use at South Pole.

\section{Steven F. Daly. 2015. ERDC/CRREL TR-15-16. Review of the Probable Maximum Flood (PMF) Snowmelt Analysis for Success Dam, http://acwc.sdp.sirsi.net/client/search/asset/1047629}

This report reviews the initial snowpack distribution assumed to be in place and available for melt in the PMF analysis of Success Dam conducted by the Corps of Engineers. This project reviewed two aspects of the initial Success Dam, CA. snow distribution: the snow covered area (SCA) distribution and the snow water equivalent (SWE) distribution. Satellite imagery were analyzed to determine the daily SCA of the Success Dam watershed from 2000 to 2014. This analysis was based on time-domain filtering of NASA's daily

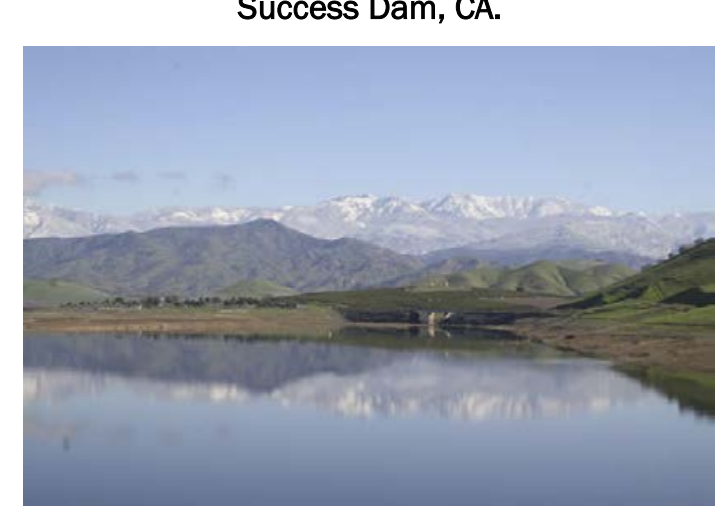
snow product. The SCA of the Success Dam watershed is highly dynamic with large day-to-day variations. The maximum 95th percentile SCA for each elevation band was selected to describe the initial snow cover in place at the start of the PMF analysis. Next the initial SWE distribution was reviewed. Above $5000 \mathrm{ft}$, the initial SWE distribution was greater than the snowmelt that occurred during the PMF and was therefore heat transfer limited. In this region, the snowmelt runoff during the PMF was insensitive to the amount of SWE. Below $5000 \mathrm{ft}$, the snowmelt was limited by the initial SWE. Runoff from this region is sensitive to the amount of initial SWE.

Rosa T. Affleck, Charles Smith, Andrew Bernier, et al. 2015. ERDC/CRREL TR15-17. Structural Condition Assessment of Reinforced Base Course Pavement, http://acwc.sdp.sirsi.net/client/search/asset/1047549

In 2011, the New Hampshire Department of Transportation (NHDOT) reconstructed 2 miles of Pickering Road in Rochester. This included building three distinct reinforcement conditions: a geogrid reinforcement within the granular base-course layer and no geotextile separator, a geotextile separator between the subgrade soil and the subbase course, and a geogrid 
reinforcement within the granular base-course layer with a geotextile separator between the subgrade and the subbase layer.

CRREL conducted a series of fallCored asphalt concrete. ing weight deflectometer (FWD) tests to monitor changes in layer moduli as the seasons changed. FWD tests occurred several times throughout the year on selected locations along the reinforced and nonreinforced (southern portion) pavement. Based on the seasonal back-calculated moduli for 2014 and 2015 values, the reinforced geogrid granular base-

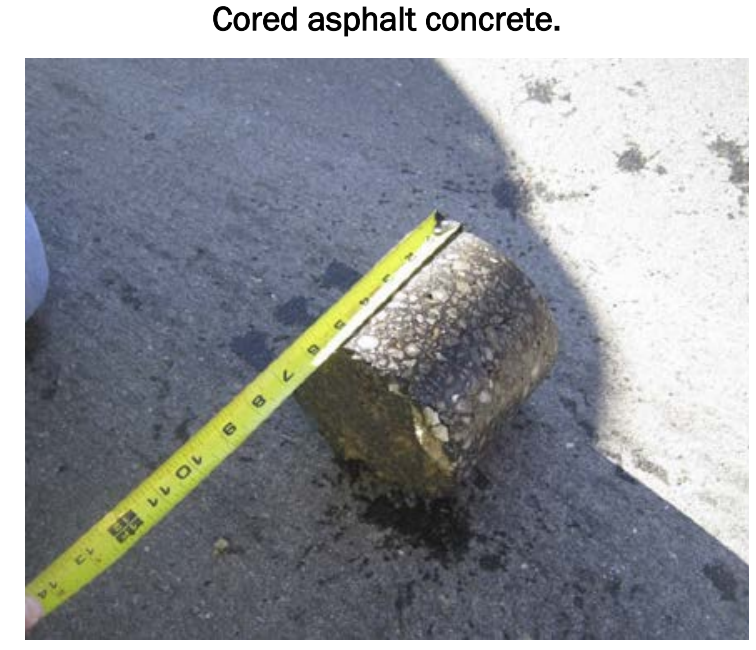
course layer provided higher moduli than the nonreinforced sections, and it appears that the aggregate layer thickness can be reduced to 33-42\% if the base course is reinforced with a geogrid mesh. This higher stiffness should allow the pavement to withstand many more traffic repetitions before fatigue cracking develops; and the geogrid should minimize the influence on thermal cracking. 


\section{Sustainable Contingency Basing}

This focus area relates to identification of the Army's required capabilities for full spectrum contingency operations. To meet the objectives of this focus area, a multi-disciplined approach is necessary to develop solutions that ensure sustainability and efficiency while eliminating redundancy in a contingency environment.

Charles T. Decker, Andrew C. Johannes, Jed B. Alvey, et al. ERDC/CERL TR-1630. Opportunities for Waste Heat Recovery at Contingency Bases, https://erdc-library.erdc.dren.mil/xmlui/bitstream/handle/11681/20652/ERDC-CERL\%20TR-1630.pdf? sequence $=1$ \&isAllowed $=y$

The energy requirements of Contingency Bases (CBs) involved in U.S. military operations on every continent are met almost exclusively with the use of diesel generators, which are relatively inefficient both in terms of fuel consumption and the large amounts of waste energy generated during their operation. Tactical generators are currently loaded only to 30 to $40 \%$ capacity, due in large part to the sizing of generators to cover large electrical loads like electric heating of space and water. This work was undertaken to estimate the amount usable of available waste heat that could be captured and reused to heat buildings and provide hot water while reducing generator fuel demand. It was found that the use of other-

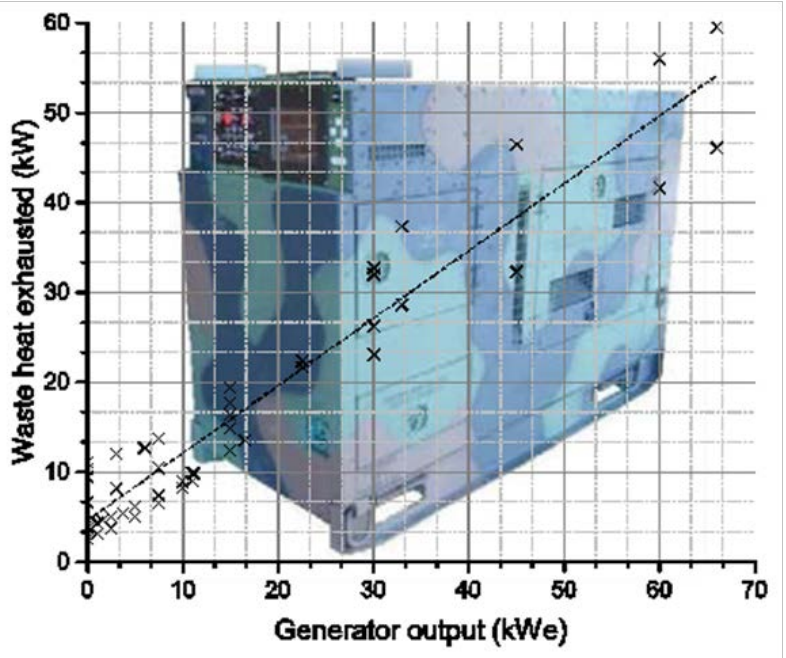
wise wasted thermal byproduct of the diesel generator for space and water heating allows loads to be consolidated so the numbers and sizes of generators can be dramatically reduced. The use cogeneration can lead to total fuel savings of nearly $20 \%$ Waste heat from five $60 \mathrm{~kW}$ generators can supply water heating for an entire 300 personnel contingency base, and in austere conditions, up to $1.75 \mathrm{gpm}$ per implementation. 
Natalie Myers. 2016. ERDC TR-16-11. Assessing Socioeconomic Impacts of Cascading Infrastructure Disruptions in a Dynamic Human-Infrastructure Network, http://acwc.sdp.sirsi.net/client/en_us/search/asset/1050668

The functionality of modern cities relies heavily on interdependent infrastructure systems such as those for water, power, and transportation. Disruptions often propagate within and across physical infrastructure networks and result in catastrophic consequences. The reaction of communities to disasters (e.g., seeking alternatives) may further transfer and aggravate the burden on surviving infrastructures, which may facilitate cascading secondary disruptions. Hence, a holistic analysis framework that integrates infrastructure interdependencies and community behaviors is needed to evaluate a city's vulnerability to disruptions and to assess the impact of a disaster. U.S. Army doctrine requires that commanders understand, visualize, and describe the infrastructure component of the J oint Operating Environment to accomplish the Army's missions of protecting, restoring, and developing infrastructure. To this end, a game-theoretical equilibrium model has been developed in a multilayer infrastructure network, to systematically investigate the mutual influence between the infrastructures and the communities. In this model, two types of infrastructure failure patterns are formulated to capture general network interdependencies; network equilibrium is extended into infrastructure and community systems to address redistribution of demand for life-supporting resources; the societal impact of disasters is estimated based on resource demand loss, cost increase, and total infrastructure failure. A real-world case study was implemented to demonstrate the proposed model and algorithm, and to reveal insights.

\section{William Brown, III. 2016. ERDC/CERL CR-16-2. SMART Energy Efficient Deployable Shelters (SEEDS). Distribution D.}

Energy plays a major role in the operation of Forward Operating Bases (FOBs) in a contingency environment. The basic building block for initial facilities/ deployed shelters is the (Army) Force Provider system and (Air Force) Basic Expeditionary Airfield Resources (BEAR) Order of Battle (BOB); each shelter has an environmental control unit (ECU). The shelter ECUs consume over $70 \%$ of the electricity generated on FOBs. To meet their intensive energy needs, 
FOBs rely heavily on convoyed or air-dropped fuel, which represents a security risk and great operational expense. Attacks on delivery mechanisms for energy supplies in Afghanistan and Iraq demonstrate that fuel-inefficient FOBs that require excessive resupply endanger troops and threaten the mission. To improve shelter thermal efficiency to reduce ECU electricity consumption and effectively reduce the total fuel consumption on FOBs and the associated logistical requirements to meet those needs, this effort: (1) refined a computational fluid dynamics (CFD) shelter model, (2) used CFD simulations to evaluate the impact of improved shelter technologies on shelter thermal performance, and (3) integrated the selected technologies into an advanced shelter design. The developed advanced shelter will be field tested to verify the CFD simulation predicted thermal performance and reduction in energy consumption.

Kathryn A. Guy. 2016. ERDC/CERL TR-16-13. Novel Anaerobic Wastewater Treatment System for Energy Generation at Forward Operating Bases: Final Report on Environmental Restoration Project ER-2218, http://acwc.sdp.sirsinet/client/en_US/search/asset/1051006

FOBs currently lack sustainable wastewater treatment options, creating operational inefficiency, personnel vulnerability, and environmental degradation. The objective of this research was to develop a sustainable wastewater treatment system for FOBs that converts wastewater contaminants, including organics and ammonia, into harvestable products

Conceptual design for integrated AnaerobicClinoptilolite-Electrolysis (ACE)wastewater treatment system.

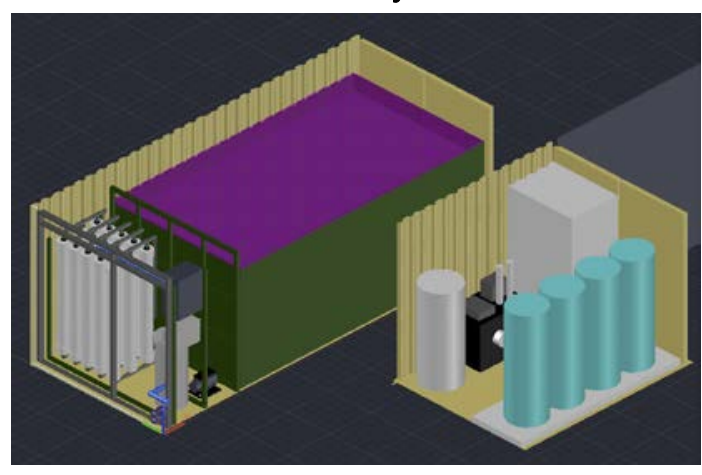
for energy production. The system aims to combine sustainable materials with recent technological advances to treat wastewater with minimal material input and reduced disposal issues, while producing a net return on energy. The wastewater treatment system designed under this project will benefit DoD by reducing the costs, logistical burden, and risks associated with wastewater management at FOBs. Further development of the technology into a full-scale unit is expected to yield an efficient system for onsite treatment that is simple to operate and produces fuels for electrical and thermal energy generation. This positive-net-energy approach will support self-sufficient-FOB design goals. The integrated system would also reduce the logistical burden and 
risks associated with transporting waste and importing fuel, chemicals, and water. The proposed system will reduce the FOB environmental footprint and impact on indigenous populations, demonstrating innovative and effective environmental stewardship.

George Calfas. 2016. ERDC/CERL TR-16-14. Construction Material-Based Methodology for Military Contingency Base Construction: Case Study of Dhaka, Bangladesh, http://acwc.sdp.sirsi.net/client/en_uS/search/asset/1051267

To sustain itself as the world's premier land power, the Army needs the capability to support expeditionary forces by projecting a minimal basing footprint with reduced logistical burdens. Strategically sited CBs allow the Army's expeditionary forces to rapidly respond and attack the enemy throughout the joint area of operations (J OA). Strategic conditions will be analyzed through the lens of eight operational energy (OE) variablespolitical, military, economic, social, Overlay of site selection construction material factors.

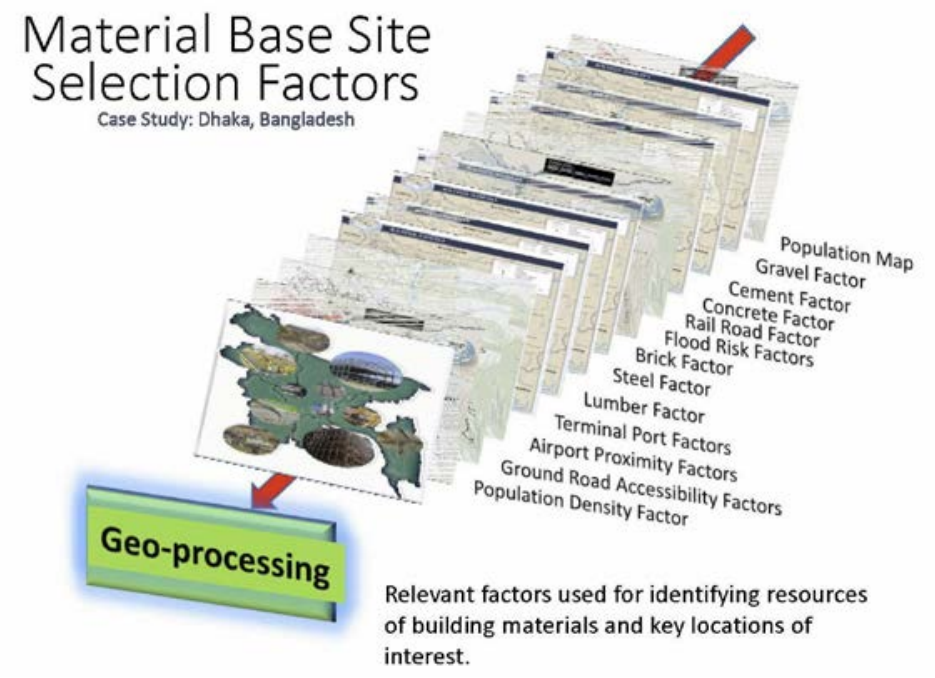
information, infrastructure, physical environment, and time (PMESII-PT). The Army has neither a well-grounded methodology nor the tools that enable this strategic decision-making capability. Decision makers require reliable information about the situational dynamics of the operational environment to anticipate the impacts that siting and operating CBs will have on the local context, and to consider the effects of the sites on the operation of CBs. This capability to anticipate CB impacts and resources draws upon knowledge gleaned from the local population and becomes particularly important for engagement operations when CBs will have a longer duration of use and interaction with the local populace. This report considers access of building materials required for the construction of CBs and develops a methodology for strategically siting CBs that can be replicated in other locations throughout the world. This work then validates the developed methodology with a case study of Dhaka, Bangladesh. 


\section{Perkins. 2016. ERDC SR-16-3. Machine Classification of Text and the Detection of Dominant Political Narratives. Limited Distribution. FOUO.}

The purpose of the Violent Events Sociocultural Analysis (VESCA) project is to improve the processing and exploitation of event data to enable a deeper understanding of operating environments. Work products include the processes and tools needed to develop and analyze an enhanced sociopolitical event data set. The work described in this report was undertaken to assess the feasibility of an approach to automating the identification of dominant political narratives in media reports for possible analysis in combination with event data. Dominant political narratives offer the potential to clarify the strategic and operational considerations that may influence tactical activities, and to understand the events that both frame the context for communication and explain how events may be interpreted or described. Results suggest that it is feasible to achieve "moderate agreement" in coding accuracy through human coding of dominant political narrative and yield reasonably accurate classification from machine automation based on that training. However, the effort is labor-intensive and methods need to be validated through further study.

John L. Vavrin and William J. Stein. ERDC/CERL TR-15-27. Mold Remediation and Recommendations to Resolve Other Major Issues in Concrete B-Huts at Bagram Airfield, Afghanistan (Distribution C).

The wooden barracks hut, or the "B-hut" is one of the easiest and quickest structures the military can build for administrative, operations, and living facilities. However, wooden B-huts offer no protection against small arms or indirect fire, are energy inefficient, support only eight Service Members, and are not easily relocatable. To improve force protection, concrete B-huts were designed and built at Bagram Airfield, Afghanistan from 2011 to 2013. However, their design created an environment characterized by mold growth, poor indoor air quality, water infiltration, and uncomfortable living temperatures in extreme weather conditions.

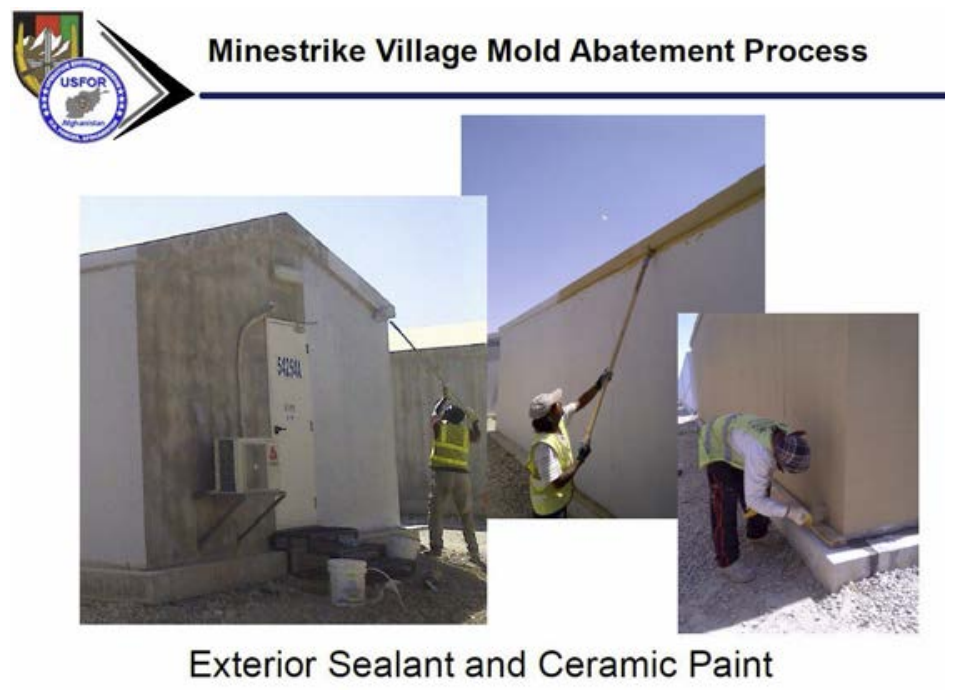


These conditions were caused by lack of tempered outdoor air, no insulation, inadequate heating and cooling systems, and water infiltration. This work developed a comprehensive solution to address mold issues and other deficiencies in these concrete B-huts, including: cleaning and drying the interior with a commercial biocide, sealing exterior surfaces and floors, installing heat recovery ventilators, painting interior surfaces with antimicrobial paint, and installing exterior insulation and radiant heaters. All recommendations were implemented except interior painting, radiant heaters, and insulation. At the time of this publication, with the exception of 1 month, monthly inspections reported no mold in the facilities. 


\section{Sustainable Natural Infrastructure}

The U.S. Army Corps of Engineers strives to protect, sustain, and improve the natural and manmade environment of the Nation, and is committed to compliance with applicable environmental and energy statutes, regulations, and Executive Orders. The Corps of Engineers is committed to ensuring that sustainability is not only a natural part of all our decision processes, but should also part of our organizational culture. The Corps, which is a steward for some of the Nation's most valuable natural resources, strives to ensure sustainable solutions that address short and long-term environmental, social, and economic considerations.

The purpose of this focus area is to engage stakeholders through forums, white papers, publications, and other means regarding DoD-related concerns with natural resources, both in terms of managing DoD assets and natural resources as they relate to international and national security and stability.

\section{Benjamin E. Barrowes. 2016. ERDC/CRREL TR-16-12. Evaluation of Electromagnetic Induction (EMI) Resistivity Technologies for Assessing Permafrost Geomorphologies, http://acwc.sdp.sirsi.net/client/en_US/search/asset/1050886}

Effective and efficient mapping of permafrost subsurface composition at scales relevant to the design and maintenance of horizontal and vertical infrastructure has been a long-standing challenge. Of utmost utility would be the development of standoff measurement techniques that could discern at the meter to submeter spatial scale and up to $10 \mathrm{~m}$ into the subsurface the presence or absence of ice features. Ground-

EMI instrument conceptual operation. The primary fields (red) produce secondary fields (blue) that are detected by the receiver coil.

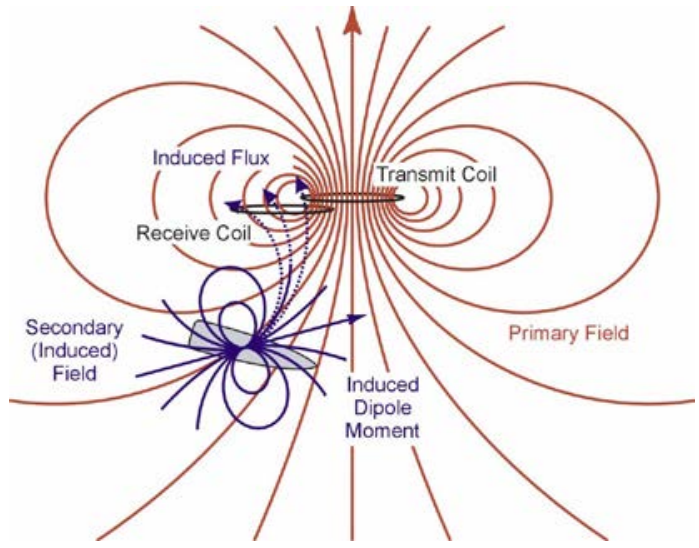
based geophysical measurement techniques, including ground-penetrating-radar, borehole logging, and electrical resistivity, have been used to interrogate the subsurface in permafrost terrains at the meters to kilometers scales. Airborne measurement techniques have broad applicability at the larger, kilometers to tens of kilometers scale and could support linear infrastructure development and terrain mapping. However, there is a broad 
need for cost effective airborne geophysical techniques to obtain high-resolution measurements of specific areas of interest. This report explores the potential application of airborne EMI methods for the investigation and mapping of permafrost and reviews current ERDC EMI survey capabilities and new opportunities, including the development of a new medium-scale autonomous EMI instrument.

\section{Matthew Hohmann. 2016. ERDC/CERL TR-16-31. A Species Distribution Modeling Informed Conservation Assessment of Bog Spicebush, http://acwc.sdp.sirsi.net/client/en_US/search/asset/1054548}

Bog Spicebush (Lindera subcoriacea) is a DoD Species at Risk (SAR) that has recently been proposed for listing under the Endangered Species Act. Roughly $60 \%$ of all known Bog Spicebush populations are found on five DoD installations: Fort Bragg, Camp Mackall, Fort J ackson, Eglin Air Force Base (AFB), and Camp Shelby J oint Forces Training Center (JFTC). This recently described species has been reported to occupy a variety of plant communities that have varying disturbance dependence, suggesting the habitat suitability of occupied sites is spatially and temporally dynamic.

Additional information about Bog Spicebush habitat requirements and potential distribution is needed to inform assessments of the species' conservation status and management needs. This project used MaxEnt, a widely applied species distribution modeling approach to generate a range-wide habitat

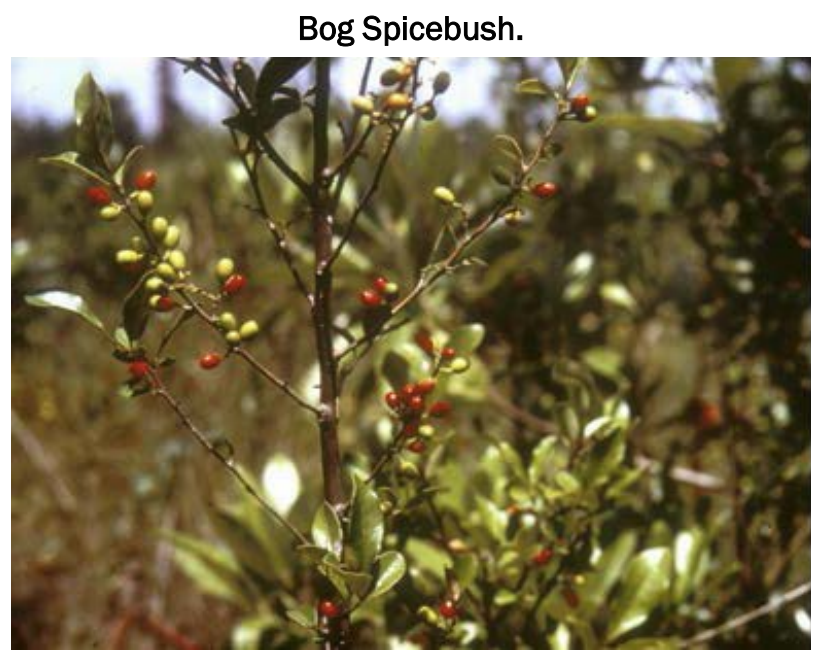
suitability map. This map was also used to identify: (1) sites warranting targeted surveys for novel populations, (2) suitable habitat for conservation and management, and (3) sites suitable for population (re)introduction. 
Matthew K. Mersel. 2016. ERDC/CRREL SR-16-5. Synthesizing the Scientific Foundation for Ordinary High Water Mark Delineation in Fluvial Systems, http://acwc.sdp.sirsinet/client/en_US/search/asset/1054567

For more than 100 years, the ordinary high water mark (OHWM) has been used to define water boundaries in a number of contexts in the United States. This Special Report summarizes the scientific literature pertaining to the indicators used to identify the OHWM in fluvial systems, building on more than a decade of research and publications related to the An anabranching portion of the Yukon River in central Alaska.

OHWM in the ongoing process to implement the Clean Water Act and the Rivers and Harbors Act of 1899. This report does not change or redefine the indicators used to identify the OHWM, nor is it a manual for how to delineate the OHWM. This report first reviews established concepts in river science that relate to the OHWM then reviews various sources of information that can be used to delineate the OHWM, discusses geographic variations in OHWM indicators among river segments, reviews human activities that can affect the OHWM, and finally presents examples of the OHWM in diverse channel types and regions.

James H. Lever. 2016. ERDC/CRREL SR-16-4. Autonomous Sea-Ice Thickness Survey, http://acwc.sdp.sirsi.net/client/en_US/search/asset/1050267

We conducted an autonomous survey of sea-ice thickness using the polar rover Yeti to tow an electromagnetic induction meter over sea ice in McMurdo Sound, Antarctica. This proof-of-concept survey aimed to demonstrate improved efficiency relative to

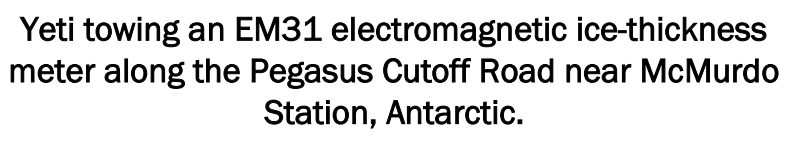
meter along the Pegasus Cutoff Road near McMurdo Station, Antarctic.

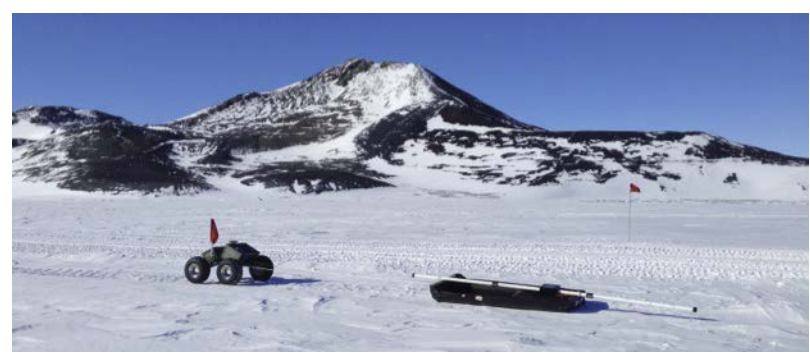


manual surveys routinely conducted to assess the safety of roads and runways constructed on the sea ice. Yeti executed the autonomous survey on 11 November 2014. This report describes the methods used, compares the measured ice-thickness profiles with manual borehole measurements, assesses the merits of autonomous surveys relative to manual ones, and describes potential future applications.

Steven Larson. 2016. ERDC/EL TN-16-2. Technology Transfer of Biopolymer Soil Amendment for Rapid Revegetation and Erosion Control at Fort A. P. Hill, Virginia, http://acwc.sdp.sirsi.net/client/en_US/search/asset/1049768

Sustainable land management at Army installations is a critical concern of the modern Army and the Army engineer. A unique soil additive consisting of a polysaccharide polymeric material, a natural product of plant/ soil rhyzobial microbial activity, was demonstrated to enhance site vegetation and control erosion. The effort was supported by the DoD ESTCP Project ER-0920. Rhizobium tropici, a catalogued symbiotic nodulator of leguminous plants (Martinez-Romero et al. 1991), is also known for its prolific production of a gel-like, extracellular polymeric substance (EPS), a biopolymer. The natural functions of the EPS in the rhizosphere include surface adhesion, self-adhesion of cells into biofilms, formation of protective barriers, water retention around roots, and nutrient accumulation. The secretion of EPS by bacteria is recognized as a cohesive force in promoting surface erosion resistance in sediments.

Rapid seed germination evident at 7 days and significant biomass production at 3 weeks post-planting.

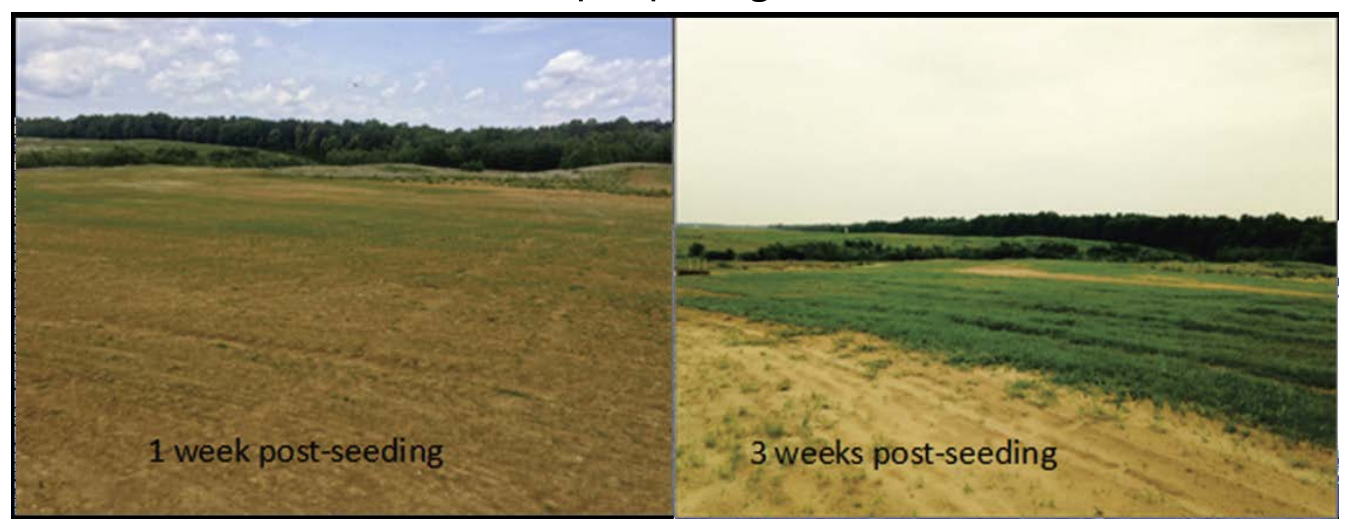


Sally A. Shoop. 2016. ERDC/CRREL TR-16-13. Image Analysis and Classification Based on Soil Strength, http://acwc.sdp.sirsi.net/client/en_US/search/asset/1050907

Satellite imagery classification is useful for a variety of commonly used applications, such as land use classification, agriculture, wetland delineation, forestry, geology, and landslide potential. However, image classification for physical properties of surface soils, such as strength or bearing capacity, is often obscured by other surface conditions, such as moisture and vegetation, although these are also indicators of soil strength. This project used remote methods of terrain analysis to search for areas suitable for vehicle or aircraft maneuverability based on slope, roughness, vegetation, soil type, and wetness and also performed direct classification of imagery based on soil strength. Using a maximum likelihood supervised classification approach, trained by a limited amount of ground-truth strength measurements, a soil strength classification was applied to WorldView- 2 multispectral satellite imagery. This paper presents the work done on the imagery classification for soil strength, the apparent relationship between the reflectance and soil strength, and the ongoing work to expand the technique to new imagery by using existing training sets.

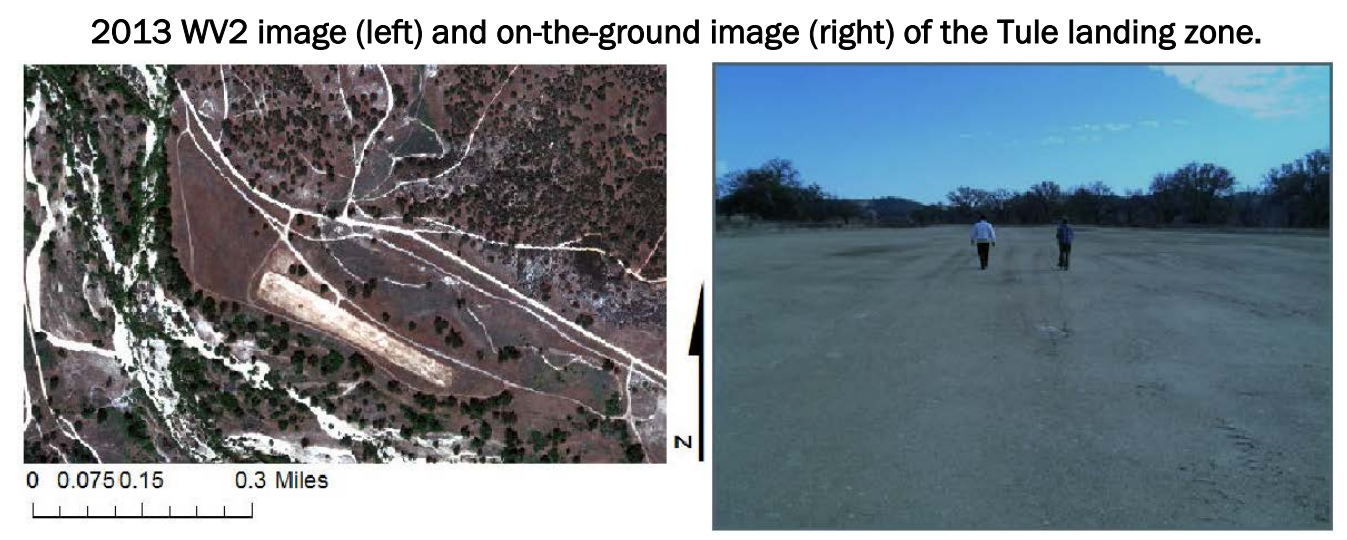

Ryan R. Busby. 2016. ERDC/CERL TR-16-9. Adaptation Strategies for Training Lands and Ranges at Fort Leonard Wood, MO, http://acwc.sdp.sirsi.net/client/en_US/search/asset/1052188

In the United States and its territories, the Department of Army manages approximately 11 million acres of land for military use. The repeated and consumptive use of these lands for military training and testing activities, which is unique to DoD, creates a significant land management challenge. Superimposed upon these types of disturbance-related impacts are climate change scenarios that predict warming and greater climatic variability for 
the foreseeable future, including more frequent and severe droughts and intense storm events.

This work identified and described several key planning and management activities that can be implemented in the face of a changing climate to ensure that training and testing ranges at Fort Leonard Wood, MO will continue to provide sustainable, realistic, and cost effective training opportunities for the warfighter well into the future.

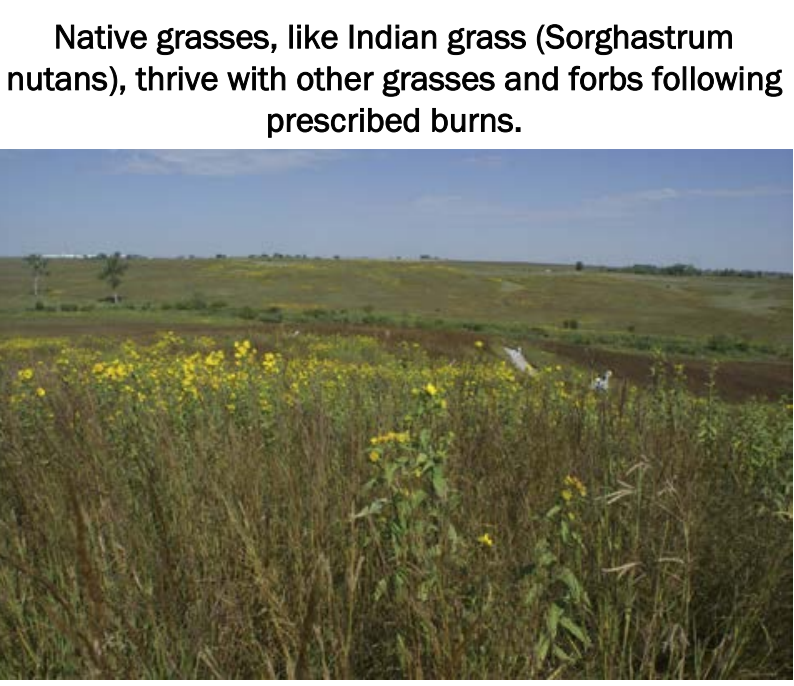

Lesley Miller. 2016. ERDC/EL SR-16-1. Nanomaterial Dispersion/Dissolution Characterization: Scientific Operating Procedure SOP-F-1, http://acwc.sdp.sirsi.net/client/en_US/search/asset/1049986

Evidence suggests that a material's dispersion and dissolution behaviors may be crucial to understanding the material's environmental risk. Since exposure risks are directly determined by the environmental fate of nano silver (nAg), extensive efforts have been put forth in elucidating the behavior of these materials in natural systems. Thus, it is important to understand the different metrics that can be used to represent nanoparticles (NPs) in a system. Given the connection between a material's dispersion and dissolution kinetics, a protocol is presented to measure the dissolution kinetics of nanomaterials using a simple 48-hour experimental protocol that uses environmentally representative waters as well as non-destructive analytical techniques. Protocols for the simultaneous measurement of the nanoparticle dispersion properties are also presented. When used with the appropriate equations listed in this scientific operating procedure, data derived from these simple experiments can provide fundamental information about the behavior of nanoparticles in different environments. 
Kathy Keane. 2016. ERDC/EL CR-16-3. California Least Tern Foraging Ecology in Southern California: A Review of Foraging Behavior Relative to Proposed Dredging Locations, http://acwc.sdp.sirsinet/client/en_US/search/asset/1049769

The California least tern (Sternula antillarum browni, hereafter CLT), one of three subspecies of the Least Tern, nests along the west coast of North America. Foraging occurs in bays, lagoons, estuaries, tidal marshes, river mouths, ponds and lakes, as well as in offshore deepwater habitats by plunge-diving for fish. Fifty species of prey fish have been identified as potential CLT prey. The CLT, listed as endangered by the Federal and California Endangered Species Acts, is afforded protection at its nesting sites in California. The relative importance of various forag-

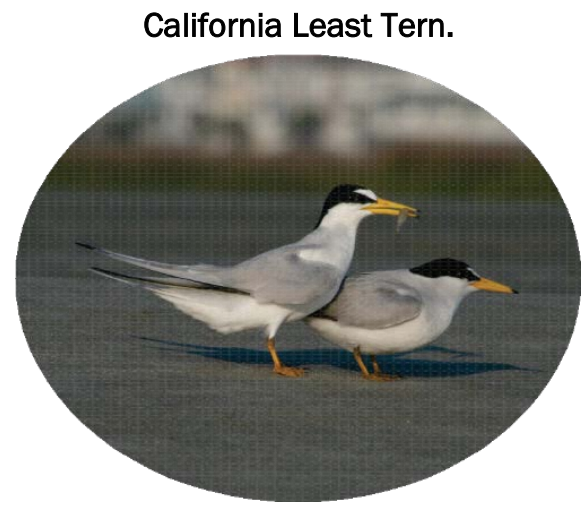
ing areas and foraging habitats near CLT nesting sites has not been evaluated, nor has official protection been designated to any CLT foraging areas, aside from seasonal limits on dredging sites recommended by the U.S. Fish and Wildlife Service (USFWS).

The U.S. Army Corps of Engineers (Corps) Los Angeles District conducts maintenance dredging along the California coast to ensure navigational access. Some of these sites are within foraging distance of CLT nesting areas. Dredging activities were generally limited to periods outside the CLT nesting season (April 15 to September 15) to avoid potential adverse effects on CLT foraging due to turbidity. This report summarizes the results of a literature review on studies and observations of CLT foraging and studies on the behavior of CLT forage fish in turbidity plumes. Results suggest that dredging activities may not substantially alter CLT foraging activity and seasonal restrictions on dredging near active CLT nesting sites provide no protections to this species and are not warranted. 
Jinelle Sperry. 2016. ERDC/CERL TR-16-3. Evaluation of 757 Species under U.S. Endangered Species Act Review on U.S. Department of Defense Lands and their Potential Impact on Army Training, https://erdclibrary.erdc.dren.mil/xmlui/bitstream/handle/11681/21101/ERDC-CERL\%20TR-163.pdf? sequence $=1$ \&isAllowed $=y$

Most land bases where U.S. Army installations reside are ecologically significant and provide refuge for a large number of the Nation's threatened and endangered plants and animals. Balancing TES management with training requirements is an increasingly difficult responsibility as the number of federally listed species grows. This work developed methods for determining impacts of potential future TES listings to Army capabilities and conducted a national level assessment of the risk to Army training by species currently petitioned or under review for Federal listing. Of the

Sprague's pipit (Anthus spragueii). Source: USFWS (Doug Backlund, Wild Photos Photography॰)

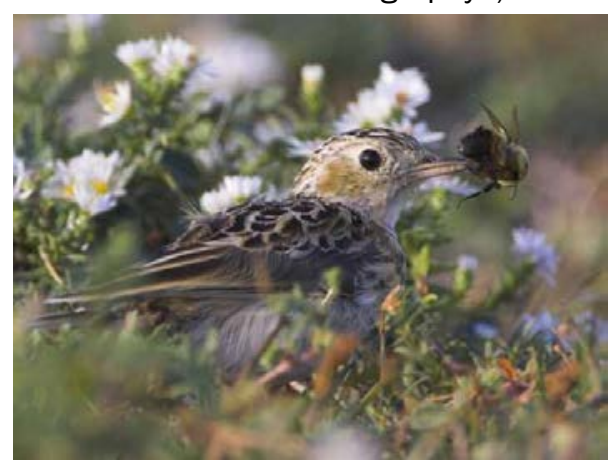
757 species reviewed, 233 were found to have the potential to be found on or near Army and Army National Guard installations. Species that were found on a large number of installations, such as the Sprague's pipit (Anthus spragueii), are those likely to have the most impact on training. Similarly, installations at greatest risk were those that housed a large number of species. Because of the large number of southeastern U.S. petitioned species, the majority of installations identified as at greatest risk are installations found in that region. Proactive management of these species, including leveraging partner opportunities, has the potential to mitigate negative impacts of Endangered Species Act (ESA) listing.

Jinelle H. Sperry, Wade Wall, and Todd Swannack. ERDC SR-15-3. Evaluation of Suitable Population and Habitat Suitability Models for Endangered Avian Species Populations on Fort Hood, TX. (Distribution D).

Fort Hood supports significant populations of two federally listed endangered species, the Golden-cheeked warbler and Black-capped vireo. Fort Hood implements intensive inventory and monitoring programs for these species to track population status and trends and mitigate population limiting factors. The impacts of management and military activities on these species and the associated continued viability of these populations have been previously evaluated using a variety of modeling approaches. This 
work: (1) evaluated the scope of endangered species monitoring, management, and assessment necessary to support installation requirements, (2) identified and evaluated models that best support installation requirements, and (3) provided suggestions to improve those models.

Four candidate models (two for each species) were identified. For Goldencheeked warblers (below, left), two models use recognized approaches and predict warbler occupancy/ abundance. Both would be good candidates for management planning and a detailed model comparison, using a common dataset, would allow a more detailed evaluation of each model's accuracy. However, the two models identified for Black-capped vireos (below, right) suffered shortcomings that may limit their usefulness for species management. Methods were recommended to improve the models.

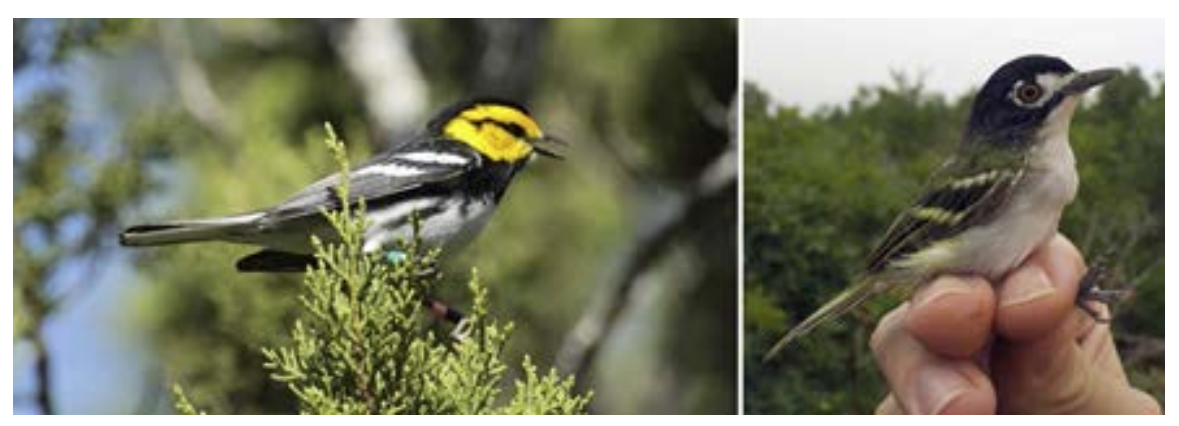

Kevin Bjella, Steve Arcone, and Thomas Douglas. 2015. ERDC/CRREL TR-15-14. Imaging of Ground Ice with Surface-Based Geophysics http://acwc.sdp.sirsi.net/client/search/asset/1045969

Electrical properties of earth materials have profound differences due to the phase change of water to ice. This contrast is useful when using electromagnetic methods to study permafrost terrains where frozen and thawed materials are intermixed. Engineering and science are in need of efficient, non-invasive tools for imaging ice and sediment composition. Borehole information is often used to map ice in permafrost terrains; but it is time consuming, expensive, and can lead to over- or under-quantification of ground ice. Advances in computing power have led to refined surface-based geophysical methods, and the goal of this study was to determine if the latest commercial technologies or system were promising for imaging ground ice and associated features and to compare the results across a variety of permafrost terrains.

Electrical Resistivity Tomography (ERT), in particular, has been effective for imaging ground ice. ERT measures the ability of materials to conduct or resist an electric current. A variation of this method, capacitive coupled 
resistivity offers the ability for continuous data collection while moving across the landscape at scales of meters to kilometers. This greatly enhances the cost efficiency, applicability, and overall usefulness of the techniques and provides the ability to view variations in permafrost ice content on these larger scales.

David Delaney, Patrick Guertin, Michael White, et al. 2016. ERDC/CERL TN16-1. Assessment of Small Arms Munitions Impacts on Natural Infrastructure in Sensitive Downrange Areas on Military Installations, http://acwc.sdp.sirsinet/client/en_US/search/asset/1048789

Large areas of high quality terrestrial natural infrastructure exist downrange of small arms training ranges on DoD installations. Live-fire training has caused concern to regulatory entities due to the potential impacts on natural resources, and to safety concerns expressed by adjoining land owners. This paper investigated whether there are reliable documented methods to quantify the number of bullets that escape the cantonment berm and end up down range via queries among Natural $\mathrm{Re}$ source peers and a technology review to document existing methods that address bullet fate on ranges. Responses to the inquiries indicate that Natural Resource personnel on military facilities or other state or Federal agencies do not have adequate tools or guidance to address the potential issue of smalls arms munition impacts within sensitive downrange areas. It was recommended that military installations further examine acoustical

Main vegetation and terrain characteristics along the two Farmers Loop transects (top to bottom: 40 , 200 , and $380 \mathrm{~m}$ ) resulting from seasonal thaw measurements.
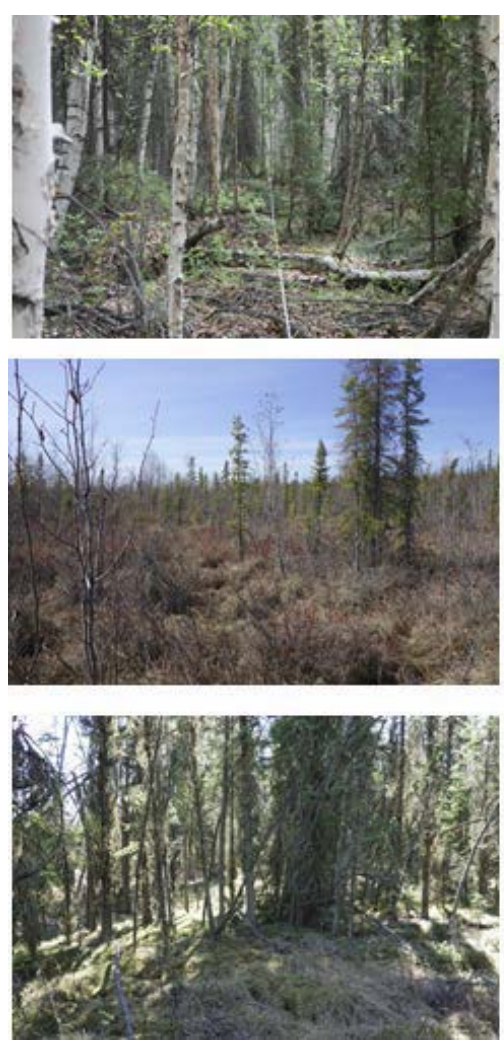
techniques for quantifying bullet overshot and ricochets into sensitive wildlife areas. Acoustical techniques offer a viable method for quantifying bullet intrusions into downrange areas. However, a more comprehensive testing procedure must be tested to gauge the effectiveness of this technique at bermed and unbermed ranges under different field conditions. 


\section{Green Remediation and Reuse}

In achieving its mission, the Corps must provide quality and responsive services in a manner that is environmentally, economically, and socially sustainable.

The purpose of this focus area is to increase awareness and activity across USACE and the Army for incorporating sustainable practices into their environmental remediation and reuse activities.

Jonathon A. Brame. 2016. ERDC/EL SR-16-2. Composition of CBRN Decontamination Effluent and Development of Surrogate Mixtures for Testing Effluent Treatment Technologies, http://acwc.sdp.sirsi.net/client/en_US/search/asset/1050948

Decontamination efforts after a chemical, biological, radiological, or nuclear (CBRN) event require large quantities of water and produce correspondingly large volumes of highly hazardous waste. This water use and production can be problematic in terms of logistics, safety, and liability during and after a domestic or military event. ERDC is developing a deployable effluent treatment sys-

Exercise in Vehicular Decontamination using the M26 mobile sprayer.

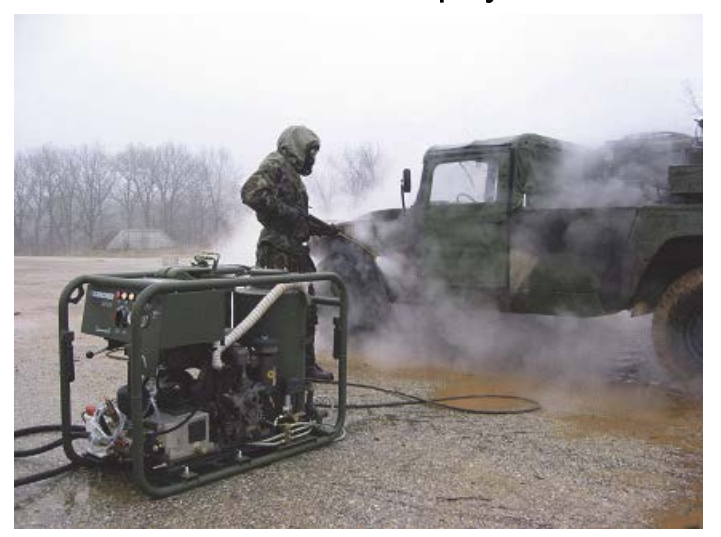
tem that could be used to treat the waste from decontamination operations for responsible discharge or potential reuse in decontamination activities. To develop such a system, it is important to understand and characterize the water that will be treated. Fortunately, there has been an absence of CBRN events to collect samples for analysis; so, the best alternative is to estimate the composition and concentration of components likely to be found in decontamination after such an event. This report summarizes our effort to provide that analysis, including the contribution of the CBRN agents, decontaminating agents, and additional materials produced as a result of washing (e.g., oil, dirt, hair, etc.). An estimate of the makeup and relevant concentrations of decontamination effluent is provided to enable testing of treatment technologies, which ensures complete removal of contaminants from decontamination effluent. 


\section{Donna J. Schell. ERDC/CERL SR-16-2. Removing Hazardous Materials from Buildings: A Training Curriculum.}

There has been little or no formalized training available within the Army for installation personnel to appropriately identify, handle, and dispose of hazardous materials generated during the renovation and/ or demolition of Army buildings. As the Army's new construction programs wind down, attention must be paid to operation, repair, and renovation of existing facilities-where hazardous materials are more likely to be encountered. An ad hoc, reactive approach to dealing with hazardous materials will adversely impact repair, renovation, and operation budgets and schedules while increasing the likelihood of regulatory noncompliance. Development of a training regimen was previously deferred but is now being addressed. Per direction from the Office of the Assistant Chief of Staff for Installation Management Facility Policy Division (DAIM-ODF), a Public Works Technical Bulletin, "Toxics Management," was completed in 2014 and published through Headquarters, U.S. Army Corps of Engineers. That publication provides guidance to address specific toxic and hazardous materials associated with buildings that are owned, leased, or otherwise controlled by the Department of the Army. For additional training documentation, this report captures a workshop-style training curriculum developed to enable installation operations and management personnel to identify, handle, and dispose of hazardous building materials in a safe, thorough, efficient, compliant, and economical manner.

\section{Zhonglong Zhang. 2016. ERDC/EL TR-16-11. Testing and Validation Studies of the NSMII-Benthic Sediment Diagenesis Module, http://acwc.sdp.sirsi.net/client/en_US/search/asset/1050526}

Nutrient simulation modules (NSMs) have been developed as "plug in" water quality modules for HEC-RAS (Hydrologic Engineering CenterRiver Analysis System) and other hydrologic and hydraulic models. The NSMs model multiple water quality constituents and biogeochemical processes in the water column. The NSMs consist of two modules: NSMI and NSMII, differing mainly in the number of water quality constituents (state variables) and kinetic processes (transformations) included. The benthic sediment diagenesis module was developed as an option module for coupling with the NSMI and NSMII water column kinetics. Sediment-water fluxes of dissolved oxygen and nutrients are computed internally rather than prescribed if the benthic sediment diagenesis module is activated. The ability of the NSMII-benthic sediment diagenesis module to correctly predict sediment-water nutrient fluxes and sediment oxygen demand was 
validated and evaluated against observed data and existing benthic sediment diagenesis models through a series of case studies. These case studies were chosen for representing various sedimentation and environmental conditions in aquatic systems. The simulated sediment-water nutrient fluxes and sediment oxygen demand over time were generally in good agreement with observed data and two model results for all test cases. This report documents testing and evaluation of the NSMII-benthic sediment diagenesis module. The report describes the testing conditions, model inputs, and model results.

Zhonglong Zhang. 2016. ERDC/EL TR-16-8. Aquatic Contaminant and Mercury Simulation Modules Developed for Hydrologic and Hydraulic Models, http://acwc.sdp.sirsinet/client/en_US/search/asset/1050727

This report offers details regarding the theory and mathematical formulations implemented in the newly developed general constituent (GC) simulation module, contaminant simulation module (CSM), and mercury simulation module (HgSM). The GC models simple kinetics for multiple size classes of solids and user-defined constituents in the water column. The CSM models the kinetics of user-defined contaminants in aquatic systems. The kinetic processes modeled in CSM include: ionization, multi-phase partitioning, degradation, photolysis, hydrolysis, volatilization, generalized second-order reaction, and transformations where one chemical species undergoes a reaction and is transformed to a daughter product. The HgSM models mercury species (elemental mercury, inorganic mercury, and methylmercury) and their cycling in aquatic systems. The three water quality modules only compute internal sources and sinks of each state variable for both water column and an underlying sediment layer. The GC, CSM and HgSM modules are written as "plug in" dynamic link libraries and compiled as GC.dll, CSM.dll and HgSM.dll respectively. These modules have been integrated into the HEC-RAS model and will also be integrated into other hydrologic and hydraulic models (e.g., AdH [Adaptive Hydraulics] and SRH-2D).

Steven Larson. 2016. ERDC TR-16-5. Evaluation of Rhizobium tropici-derived Biopolymer for Erosion Control of Protective Berms. Field Study: lowa Army Ammunition Plant, http://acwc.sdp.sirsi.net/client/en_US/search/asset/1050309

A Rhizobium tropici produced biopolymer was applied to an explosion protection berm at the Iowa Army Ammunition Plant (IAAAP) to stabilize the soil, prevent loss of berm height, reduce erosion, and increase the rate and extent of revegetation. The berm was recontoured, and a hydroseeder 
was used to apply biopolymer with grass seed. The control area received plain water and seed. Evaluated biopolymer application methods include single surface application, double surface application, and a double application at depth, with the first application 2-ft below ground surface (bgs), and the second on the surface.

A Light Detection and Ranging (LiDAR) survey evaluated soil movement from the berm slope over 3 years. The double application of the biopolymer at depth was the most effective application method, as determined by calculating soil loss and surface roughness, followed closely by the double surface application. At 19 months post-treatment, a landslip was observed in the treated area that received the double surface application of the biopolymer. There was no evidence of soil cracking in any of the other treated areas. The slip appears to be due to an indentation in the crest of the berm that channeled runoff water into the area of the slip. Slope stabilization using biopolymer is approximately half the cost of construction and maintenance of traditional earthen berms over a 30year period, due to lower installation and maintenance costs.

Steve L. Larson. 2016. ERDC/EL TR-16-7. Flexible Reactive Berm (FRBerm) for Removal of Heavy Metals from Runoff Water: ER-1213 Treatability Study, http://acwc.sdp.sirsinet/client/en_US/search/asset/1050308

SAFRs located on DoD facilities are, in many cases, constructed next to wetland areas. These wetlands represent a potential point of regulatory interest as they are at risk from heavy metal contamination. Access to wetland areas is typically limited due to a lack of roads. Standard environmental remedial options and monitoring
Comparison of surface rutting and vegetative growth after 6 months of weathering between the untreated control (Left) and the biopolymer-treated area (Right).

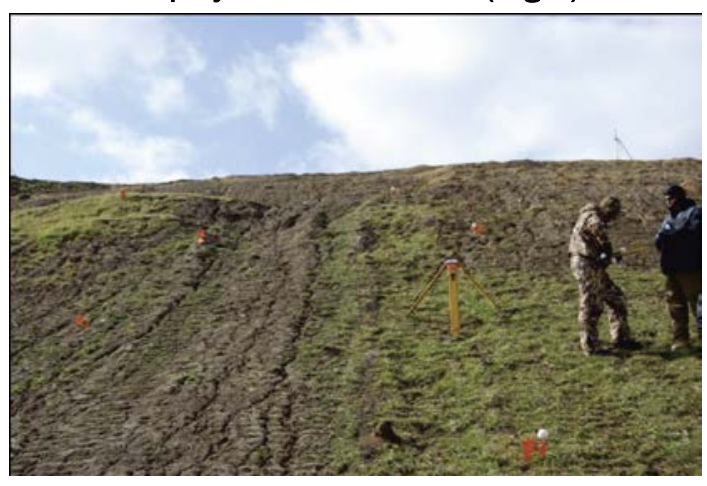


techniques are expensive to implement due to the nature of the terrain and seasonal changes in water flow. Metals are highly associated with the soil particles making up the total suspended solids (TSS) in the runoff water. Reactive materials were assembled into a barrier similar to erosion control socks. Socks were constructed using a nonwoven geotextile filled with well-graded sand, amended with 5\% weight: weight, w:w) iron/manganese-oxides (TRAPPS ${ }^{\mathrm{TM}}$ ) and/ or 5\% (w:w) treated apatite. The socks were tested under mesoscale lysimeter conditions and removal of metals from solution was confirmed. The reactive socks adsorbed greater than $95 \%$ of metals in the solution. Once the reactive material was exhausted, it was tested and found to pass the Toxicity Characteristic Leaching Procedure (TCLP) test for placement in a non-hazardous waste landfill. Positioning of the socks in the pathway of runoff water for the field demonstration was determined using predictive models for surface runoff.

\section{Jay Clausen. 2016. ERDC TR-16-4. Impact of Incremental Sampling Methodology (ISM) on Metals Bioavailability, http://acwc.sdp.sirsinet/client/en_US/search/asset/1049686}

This study assessed the impact of the ISM on metals bioavailability through a series of digestion and in vivo experiments. These tests used Eisenia fetida and Lolium rigidum in both milled and unmilled loam and sand soil containing antimony, copper, lead, and zinc obtained from Donnelly Training Area, AK. No significant differences in metal levels were evident between milled and unmilled soil for E. fetida, and uptake of lead by $\mathrm{L}$. rigidum in sand yielded lead recoveries comparable with Method 3050 analysis of soil. In contrast, L. rigidum grown in loam had

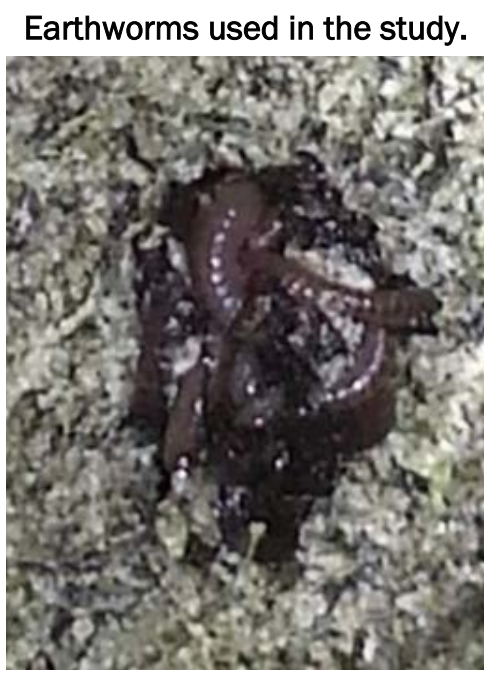
much lower recoverable lead. Milling of the soil as part of the ISM process had no significant impact on the lead species distribution. In comparison with Method 3050, the alternative digestion tests involving the use of glycine; oxalate; ethylenediaminetetraacetic acid (EDTA); or alternative digestion procedures, such as the synthetic precipitation leaching procedure (SPLP) and the TCLP, yielded lower recoveries of lead for all soil particle sizes and soil types. Diffusive gradient in thin films experiments yielded metal concentrations positively correlated with E. fetida concentrations. 
The physiologically based extraction technique (PBET) positively correlated with bulk soil concentrations and $\mathrm{E}$. fetida tissue concentrations for all soils evaluated.

Jay L. Clausen. 2016. ERDC/CRREL TR-16-10. Passive Gamma-Ray Emission for Soil-Disturbance Detection, http://acwc.sdp.sirsi.net/client/en_US/search/asset/1050706

Human- terrain interactions, such as trafficking and excavation, cause changes to soil bulk density and porosity via compaction or mechanical bulking. The degree of compaction, as measured by bulk density, is a physical indicator of changing patterns of human- terrain interaction. Because soil radionuclide activity is a function of the mass content of the radionuclide and the volume of soil,

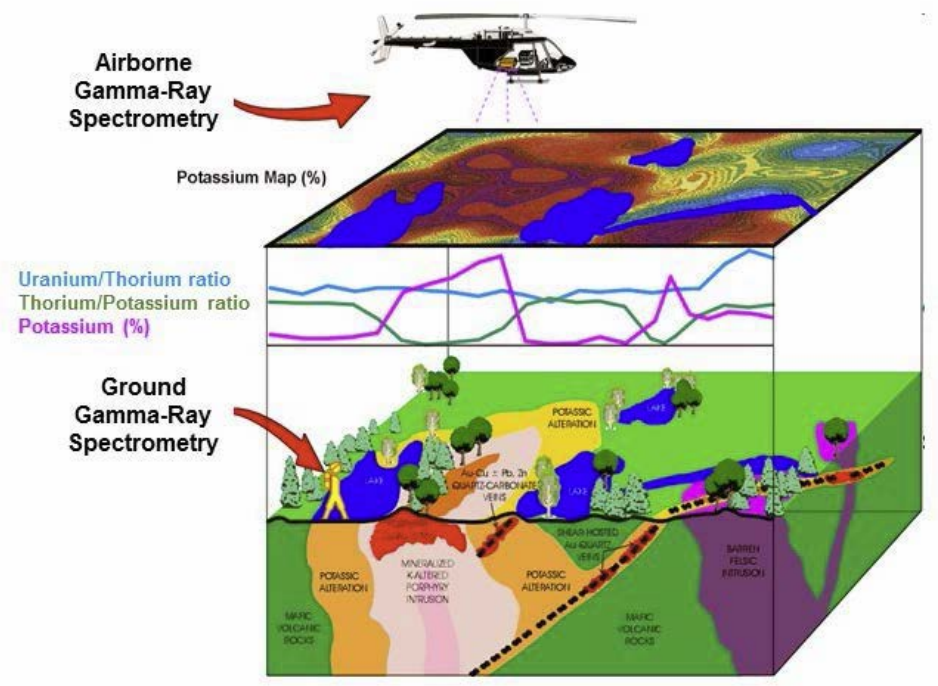
the spectral signature of the naturally occurring soil radioisotope Potassium-40 (40K) should be sensitive to changes in the soil bulk density and reflect the soil's disturbance history. If natural variations from geology and soil texture are systematic and predictable, one could map spatiotemporal bulk density changes relative to some standard state as a metric of terrain disturbance. However, the natural variation in soil $40 \mathrm{~K}$ content is unknown and may confound density determinations via radionuclide activity measurements. This study used a handheld sodium iodide gamma-ray detector to collect in situ gamma-ray spectra of four soils as a function of their potassium content, bulk density, texture, and water content. A statistically significant difference between the $40 \mathrm{~K}$ activity of uncompacted and compacted soil suggests that in situ 40K gamma-ray emissions from soils are a sensor modality useful for soil-disturbance detection. 
Michael R. Walsh. 2016. ERDC/CRREL MP-16-2. A Portable Burn Pan for the Disposal of Gun Propellants, http://acwc.sdp.sirsi.net/client/en_US/search/asset/1052146

Munitions for indirect fire weapon systems are issued with a full complement of propellant charges. Excess charges are typically not turned in and are destroyed by open burning as part of the unit's training. Burning of the charges can result in up to $20 \%$ of the propellant remaining in the form of residues on the ground. A portable propellant burn pan system was design and demonstrated as part of ESTCP Project ER-201323 to enable safe, environmentally effective training of the military. Tests have demonstrated a $99.98 \%$ reduc-

Prototype burn pan.

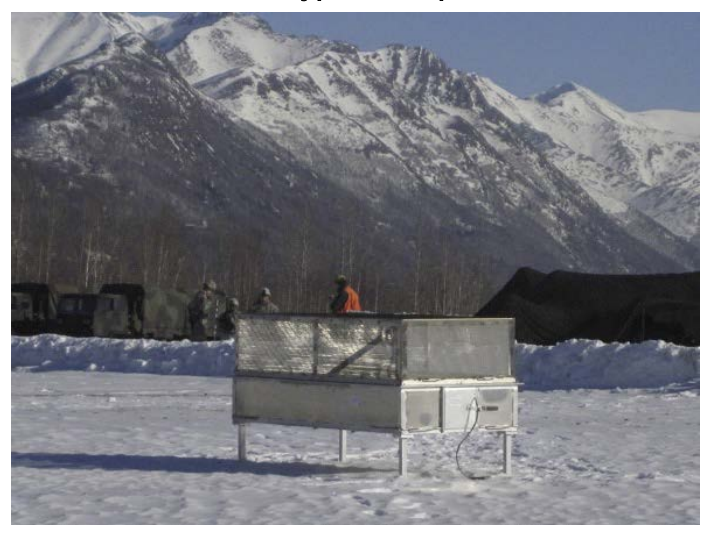
tion in combustible mass of the charges, less than $0.001 \%$ of the energetics in the burn pan ash, energetics concentration of less than $0.5 \%$ in the residual ash, and no detectable difference in energetics in the soil surrounding the pan after burning over $450 \mathrm{~kg}$ of charges. Performance objectives for the burn pan device were met or exceeded by the final system design. Costs associated with acquisition, implementation, use, and maintenance of the burn pan system are reasonable. The CRREL portable propellant burn pan training device has been enthusiastically accepted by all who have participated in the ER-210323 test and demonstration program.

Jason C. Weale. 2016. ERDC/CRREL TR-16-15. Aviation Fuel Ignition and Burn Behavior in Antarctica, http://acwc.sdp.sirsi.net/client/en_US/search/asset/1051386

The USAP currently employs a combination of DoD and Federal Aviation Administration Airfield Rescue Fire Fighting (ARFF) standards that were developed for traditional airfield environments with runways and associated facilities constructed on soil and pavements. These requirements originated from results obtained during fuel-spill-triggered pool fires and their resulting extinguishing needs. There are no known standards describing the combustion behavior at Antarctic temperatures of AN-8, JP-8 ("J et propellant 8," a kerosene-based fuel), J et-A, or other aircraft fuels spilled on airfields built on sea ice, glacial ice, and deep snow. Laboratoryscale samples of these airfield surfaces were constructed; and increasing volumes of J et-A fuel was spilled on each at decreasing temperatures, and 
fuel ignition was immediately attempted. We determined that in a controlled laboratory environment, Antarctic airfield materials and the cold environment significantly influence the ignition and combustion characteristics of J et-A by combining to create a situation where the aviation pool fire typical in temperate environments is highly unlikely. Modifications to the existing USAP ARFF response criteria, procedures, and resources required to meet the actual risks should be investigated. We also recommend changing the Antarctic ARFF tactics to (1) first get the people out of the aircraft and then (2) deal with the fire because the primary risk following an incident is likely to be hypothermia rather than fire-induced injuries.

\section{Linda Nelson. 2016. ERDC/EL CR-16-5. Complete Host Range Testing on Common Reed with Potential Biological Control Agents and Investigation into Biological Control for Flowering Rush, http://acwc.sdp.sirsi.net/client/en_US/search/asset/1050686}

The noctuid moths, Archanara geminipuncta and A. neurica, were selected as the most promising candidates for biological control of common reed. Successful larval development was only found on Phragmites spp., but development was also possible on the native North American subspecies P. australis subsp. americanus. However, open-field oviposition tests showed a strong preference of females for both European and introduced P. australis. Because of the higher egg mortality on native reed, the authors expect any impact of A. neurica and A. geminipuncta on the native reed P. australis subsp. americanus to be negligible, should the noctuids be released in North America. A biological

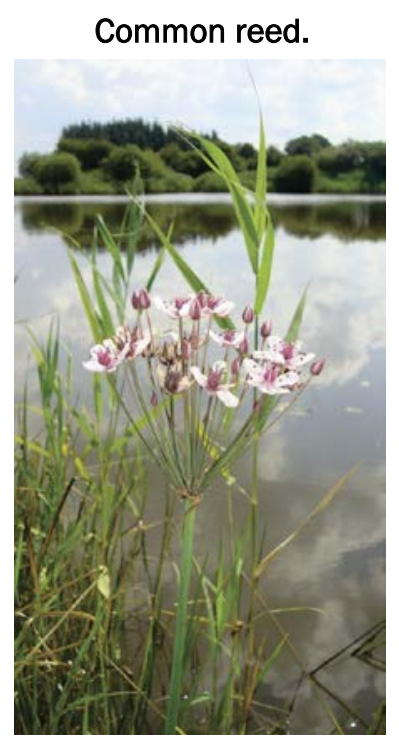
control project for flowering rush was started in spring 2013. According to the authors' literature survey, the semi-aquatic weevil, Bagous nodulosus, is the most promising potential agent for biological control. During various field surveys in Northern Germany, the Czech and Slovak Republics, Hungary, Poland, and Serbia, the authors collected several hundred adults of B. nodulosus, established a rearing colony, and started with sequential nochoice oviposition tests. So far, no eggs were found on any of the 22 test plants offered. The authors also found the other five herbivore species recorded as monophagous on flowering rush and started work with a second weevil, B. validus. 
John M. Nestler. 2016. ERDC/EL CR-16-4. Side Channels of the Impounded and Middle Mississippi River: Opportunities and Challenges to Maximize Restoration Potential, http://acwc.sdp.sirsi.net/client/en_US/search/asset/1050690

A 2.5-day interagency workshop attended by river scientists and engineers was held in Cape Girardeau, MO, from 10- 12 J anuary 2011. The goal of the workshop was to develop conceptual models (CMs) to guide side channel restoration planning for the Middle Mississippi River. Side channels support a wide range of ecological processes, functions, and biota in large river systems like the Middle Mississippi. CMs are needed to link the physical, chemical, climatic, and human factors shaping side channel habitat dynamics to help restoration planners select an optimum restoration strategy. The workshop attendees were organized into three breakout groups (each with a facilitator and recorder) that were tasked with developing their own $\mathrm{CM}$ describing ecological dynamics of side channels. The breakout groups met in plenary sessions to receive instructions, share progress, and to draw final conclusions at the end of the workshop. Each breakout group developed unique, but complementary, CMs that represented one perspective of the complex, multidimensional environmental and institutional reality of side channels restoration. It is concluded that CMs (like population models) cannot simultaneously maximize generality, realism, and accuracy; only two of these functions can be maximized at the expense of the third. As with all $\mathrm{CMs}$, these are works-in-progress that represent the current state of understanding and practice for this ecosystem as perceived by the individual experience, training and creativity of the workshop attendees.

\section{Billy E. Johnson. 2016. ERDC/EL TN-16-1. CONUS Demonstration Site Selection for Surface Water Characterization in Remote, Sparse-Data Environments: Calleguas Creek Watershed, Ventura County, California, http://acwc.sdp.sirsinet/client/en_US/search/asset/1049467}

The purpose of this Environmental Qualities Technology (EQT) technical note is to document the site selection criteria, available data present, and site characterization in the Calleguas Creek Watershed, Ventura County, CA for the purpose of demonstrating and validating the models being developed under the EQT Focus Area entitled "Surface Water Characterization in Remote Sparse Data Environments." This work unit will be developing a landscape-scale model capable of simulating flow, sediment, and contaminants across large spatial and temporal scales. The output from this system will be used to develop boundary conditions for the HEC-RAS to model detailed 1-D and 2-D channel sedimentation and contaminant fate and transport. The CONUS demonstration study will not only validate 
the process descriptions found within the modeling systems but will also be used to test and debug the Surrogate Watershed Approach to model parameter estimation and the Source Zone Loading toolkit being developed within the focus area.

Victor F. Medina. 2016. ERDC/EL TR-16-3. Testing of the KRIA lonizing Water Treatment System for Waters Contaminated with Diesel, PCBs, and Nutrients (Nitrogen Forms), http://acwc.sdp.sirsi.net/client/search/asset/1048390

This project evaluated the KRIA water treatment system (also known under the trade name ECOSOAR) for treatment of three environmental contaminants: diesel fuel, Polychlorinated Biphenyls (PCBs) (arochlor 1254) and nutrients (nitrogen forms). The KRIA water treatment system works by charging water with the superoxide radical (O2-), which is electrochemically generated from oxygen in the atmosphere. At the injection site, both cavitation and microbubble reactions may also occur. A review of the literature indicates that superoxide is a relatively weak radical, but it can work both oxidatively and reductively. A review of the literature also showed that superoxide can transform chlorinated solvents

Field deployment of the KRIA water treatment system.

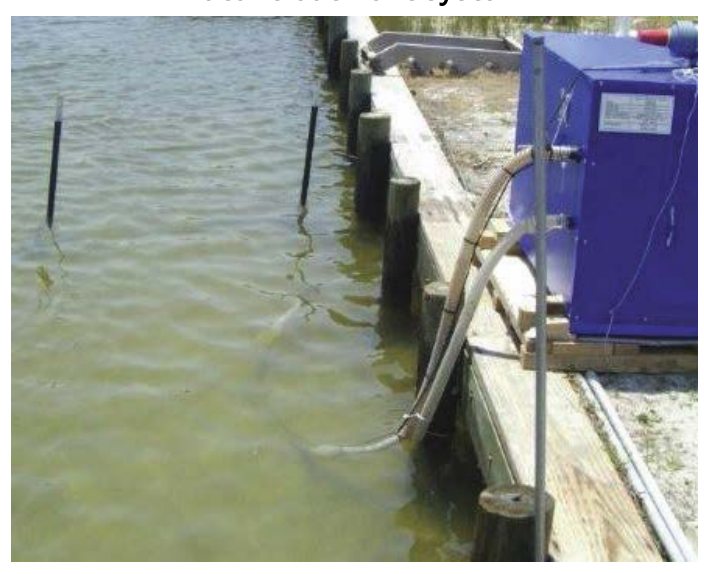
and microcystin (a toxin associated with algae). Studies of the KRIA yielded promising results, but most of these studies lacked sufficient control to isolate variables, possibly casting doubt on the exact nature of the mechanism. Background studies were conducted to evaluate the KRIA's effect on water. The KRIA charged water for 135 minutes and was compared to a control in which the superoxide valve was turned off. It was found that the superoxide charging resulted in elevated (approximately threefold) levels of oxygen, which led to the water being supersaturated (by approximately 300\%). Conductivity was also increased, presumably due to the addition of charged oxygen species into the water. These elevated levels persisted for at least 24 hours after the charging, suggesting that the effect was persistent. The team also documented elevated concentrations of superoxide ion after charging. Treatment of diesel resulted in a 58\% increase in removal compared to the control reactor, and this was statistically sig- 
nificant. Treatment of PCBs resulted in a 20\% increase in removal as compared to the control, and was also statistically significant. Treatment of nutrients (ammonia and nitrate) did not appear to result in any changes to their respective concentrations.

Richard A. Cole. 2016. ERDC/EL TR-16-5. The Biodiversity Security Index: $A$ New Metric for Benefits from USACE Ecosystem Restoration Projects, http://acwc.sdp.sirsi.net/client/search/asset/1049469

This technical report summarizes progress made in the development of the Biodiversity Security Index (BSI), a new nonmonetary metric designed for use by USACE to indicate the environmental benefit from ecosystem restoration projects planned and implemented by USACE. The BSI was designed to compare ecosystem restoration benefits across plans during project planning and across projects during annual ranking of projects for budget recommendations. It may also be used to compare monitored actual project performance with planned performance. The information presented herein is a synthesis of unpublished research and the results of previously published and draft technical reports. This publication describes the need for a new metric; the main metric elements; how the main metric elements are calculated and assembled into a metric unit; and the advantages the BSI offers in comparison to other metrics. It is not intended to serve as an implementation manual (which is under separate development). The intended audience is USACE planners and collaborators and others who are generally familiar with the USACE six-step planning process.

Victor F. Medina. 2016. ERDC/EL TR-16-10. Laboratory-Scale Demonstration Using Dilute Ammonia Gas Induction of Alkaline Hydrolysis Treatment of Soil Chlorinated Propanes and Explosives, http://acwc.sdp.sirsi.net/client/en_US/search/asset/1050487

Many environmental contaminants are amenable to degradation by alkaline hydrolysis. This project explored the use of ammonia gas to raise soil $\mathrm{pH}$ to stimulate alkaline hydrolysis. When ammonia gas dissolves in water, it forms ammonium ion, which consumes hydrogen ions $(\mathrm{H}+)$, thereby increasing $\mathrm{pH}$. This
Schematic of batch reactor used for halogenated propane and explosives degradation studies.

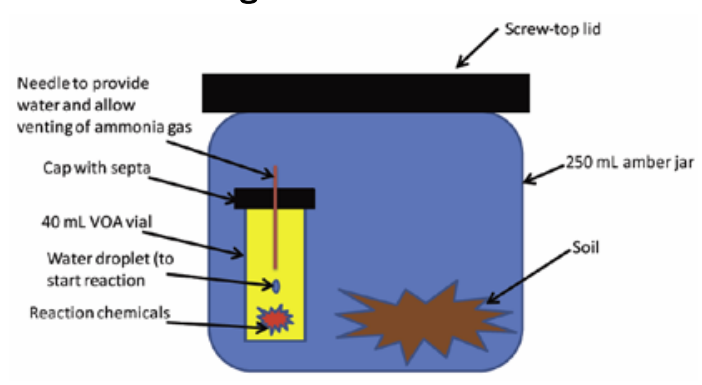


study established that $5 \%$ ammonia in air can increase soil $\mathrm{pH}$ from 7.5 to 10.3. Batch studies indicate that this $\mathrm{pH}$ increase can stimulate alkaline hydrolysis reactions, resulting in the degradation of chlorinated propanes (trichloropropane, dichloropropane) and explosives (2,4,6-trinitrotoluene, nitrobenzene, and cyclotrimethylene-trinitramine [RDX]). A column study was conducted focusing on evaluating the penetration of ammonia and subsequent $\mathrm{pH}$ change. The study showed $\mathrm{pH}$ penetration of $20 \mathrm{~cm}$ in a $2.5 \mathrm{~cm}$ diameter column over 7 days, with a flow of $5 \%$ ammonia gas at 1 sccm (standard cubic centimeter per minute). Chlorinated propane concentrations were reduced from levels of as high as $2400 \mathrm{\mu g} / \mathrm{kg}$ to as low as non-detect. A small amount of these were captured in the column off gas. The team also explored whether ammonia gas exposure could stimulate metabolic activity of ammonia-oxidizing microorganisms. A 283-day experiment did not result in any measureable increase in ammonia-oxidizing microorganisms, but the team found significant increases in soil nitrogen concentrations.

Robyn A. Barbato, Karen L. Foley, and Charles M. Reynolds. 2015. ERDC/CRREL TR-15-6. Soil Temperature and Moisture Effects on Soil Respiration and Microbial Community Abundance, http://acwc.sdp.sirsi.net/client/search/asset/1042506

Soil biological processes are influenced by dynamic soil descriptors, such as water potential and temperature, and more stable factors, including organic matter content and particle size distribution. To better understand how soil temperature and soil water potential influence microbial activity, soil respiration was measured in laboratory incubations of four different soils.

Though three of the soils had the same soil texture, they varied considerably by $\mathrm{pH}$ and soil nutrient concentrations. The soils were found to vary in how their native soil microbes responded to a range of soil water potential and temperature values, with soil activity being highest at approximately $30^{\circ} \mathrm{C}$ and $-33 \mathrm{kPa}$. Further, the peak respiration rate for the soil with the highest measured organic matter content was $329.8 \mathrm{mg} \mathrm{C}-\mathrm{CO}_{2} \mathrm{~m}-2$ day-1 and the rate for the soil with the lowest measured organic matter content was 14.7 $\mathrm{mg} \mathrm{C}-\mathrm{CO}_{2} \mathrm{~m}-2$ day-1. Those soils with elevated organic matter content also contained the highest abundance of bacteria and archaea. Across all soils, if the moisture content was optimal but the temperature was around $5{ }^{\circ} \mathrm{C}$, the respiration rate was reduced. Therefore, microbial activity may depend more on temperature though moisture clearly had an effect on activity. 
Kevin Bjella. 2015. ERDC/CRREL TR-15-15. Naval Arctic Research Laboratory (NARL) Subsurface Containment Berm Investigation, http://acwc.sdp.sirsi.net/client/search/asset/1046351

The former Navy Arctic Research Laboratory Airstrip Site in Barrow, AK, has a

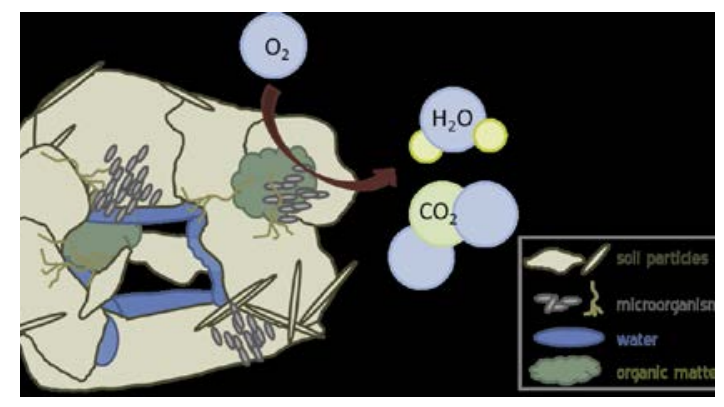
Conceptual model of a soil pore, emphasizing soil microorganisms' role in heterotrophic respiration.

history of

fuel spills. Various methods have been used to remediate the site, including installing a subsurface containment berm and associated recovery trenches. The containment berm was designed to create a raised permafrost feature that effectively prevents free product migrating from the upstream side to the downstream side.

This study focused on using nonintrusive GPR techniques coupled with ground probing and desktop thermal analyses to assess if these methods could help to determine whether the containment berm is functioning as designed (i.e., effectively decreasing active-layer thickness and raising the permafrost table). The results demonstrate that these GPR methods were useful for this study and that the berm is effectively raising the permafrost table along the survey transects explored.

\section{Stephen D. Cosper. PWTB 200-1-143. Update of Opportunities for Reducing Construction and Demolition Waste from Residential Communities Initiative (RCI) Programs, http://www.wbdg.org/ccb/ARMYCOE/PWTB/pwtb_200_1_143.pdf}

C\&D debris accounts for up to $80 \%$ of some installations' solid waste streams. This large waste stream is most critical where an installation is removing large numbers of World War II-era wood buildings and where new construction programs such as the RCI require the demolition of existing facilities. Even if the Facility Reduction Program and new MILCON programs are more modest, C\&D debris constitutes a significant solid waste burden for Army installations. 
Timber salvage at Twin Cities Army Ammunition Plant, MN in 1995.

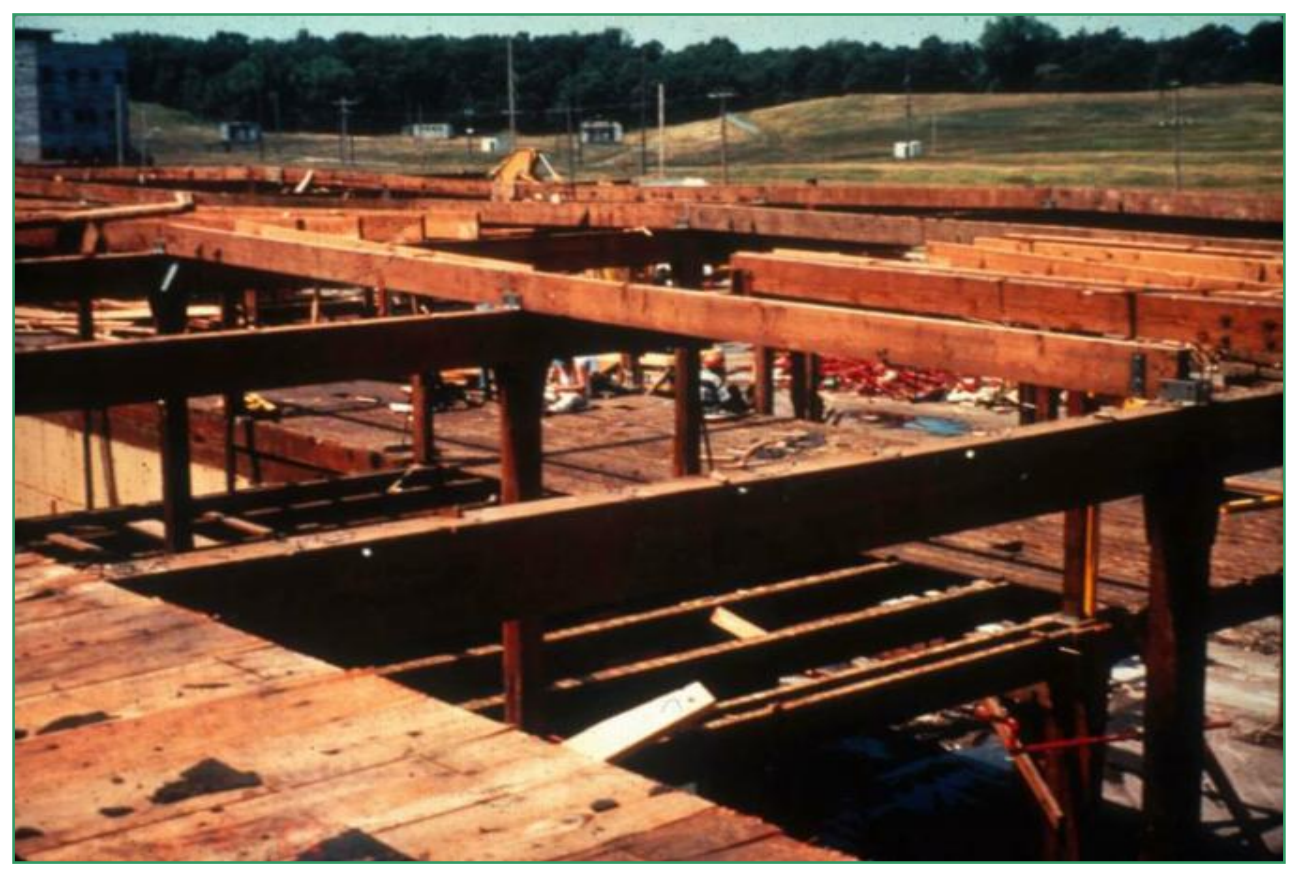

This work studied 12 family housing unit designs from four Army properties and one Air Force property. The buildings represented a large portion of the family housing buildings to be removed at Army installations, then and in the foreseeable future. The procedures and supporting data outlined in this PWTB allow for assessing the material content of buildings and will enable a relatively quick quantity take-off to be established to determine opportunities for debris reduction. It is important to note that no single quantity for material content is applicable to all buildings, construction types, and locations. Therefore, several building categories are described to address a range of project-specific conditions. 


\section{Acronyms and Abbreviations}

\begin{tabular}{|c|c|}
\hline$\underline{\text { Term }}$ & Definition \\
\hline ACE & Anaerobic-Clinoptilolite-Electrolysis \\
\hline AdH & Adaptive Hydraulics \\
\hline AFB & Air Force Base \\
\hline AHF & Anharmonic Folds \\
\hline ANSI & American National Standards Institute \\
\hline ARFF & Airfield Rescue Fire Fighting \\
\hline AT\&T & American Telephone \& Telegraph \\
\hline BDI & Bridge Diagnostics, Inc. \\
\hline BEAR & Basic Expeditionary Airfield Resources \\
\hline BMP & Best Management Practice \\
\hline $\mathrm{BOB}$ & BEAR Order of Battle \\
\hline BSI & British Standards Institute \\
\hline$C \& D$ & Construction and Demolition \\
\hline CA & Capability Approach \\
\hline CAD & Computer-Aided Design \\
\hline CASI & Center for the Advancement of Sustainability Innovations \\
\hline CB & Contingency Base \\
\hline CBRN & Chemical, Biological, Radiological, and Nuclear \\
\hline CCAFS & Cape Canaveral Air Force Station \\
\hline CCAFSIAHD & Cape Canaveral Air Force Station Industrial Area Historic District \\
\hline CERL & Construction Engineering Research Laboratory \\
\hline CFD & Computational Fluid Dynamics \\
\hline CLT & California Least Tern \\
\hline $\mathrm{CM}$ & Conceptual Model \\
\hline CNT & Carbon Nanotube \\
\hline CONUS & Continental United States \\
\hline CR & Contract Report \\
\hline CRREL & Cold Regions Research and Engineering Laboratory \\
\hline CSM & Contaminant Simulation Module \\
\hline CVWF & Central Vehicle Wash Facility \\
\hline DA & Department of the Army \\
\hline DAIM-ODF & Assistant Chief of Staff for Installation Management Facility Policy Division \\
\hline
\end{tabular}




\begin{tabular}{|c|c|}
\hline$\underline{\text { Term }}$ & Definition \\
\hline DHS & Department of Homeland Security \\
\hline DNA & deoxyribonucleic acid \\
\hline DoD & U.S. Department of Defense \\
\hline DPW & Directorate of Public Works \\
\hline DSC & Differential Scanning Calorimetry \\
\hline DTE & Defence Training Estate \\
\hline DX & Direct Expansion \\
\hline EAL & Environmentally Acceptable Lubricant \\
\hline ECM & Energy Conservation Measure \\
\hline ECU & Environmental Control Unit \\
\hline EDTA & diaminoethanetetraacetic acid \\
\hline EFOB-L & ERDC-CERL Forward Operating Base Laboratory \\
\hline EKO & Engineering Knowledge Online ${ }^{\mathrm{TM}}$ \\
\hline EL & Environmental Laboratory \\
\hline EMI & Electromagnetic Induction \\
\hline EMP & Energy Master Planning \\
\hline EN & Electroless Nickel \\
\hline EPS & Extracellular Polymeric Substance \\
\hline EQT & Environmental Quality Technology \\
\hline ERDC & U.S. Army Engineer Research and Development Center \\
\hline ERDC-CERL & $\begin{array}{l}\text { Engineer Research and Development Center, Construction Engineering } \\
\text { Research Laboratory }\end{array}$ \\
\hline ERT & Electrical Resistivity Tomography \\
\hline ESA & U.S. Endangered Species Act \\
\hline ESTCP & Environmental Security Technology Certification Program \\
\hline FHWA & Federal Highway Administration \\
\hline FOB & Forward Operating Base \\
\hline FOUO & For Official Use Only \\
\hline FRP & Fiber-Reinforced Polymer \\
\hline FWD & Falling Weight Deflectometer \\
\hline $\mathrm{FY}$ & Fiscal Year \\
\hline GC & General Constituent \\
\hline GFRP & Glass Fiber-Reinforced Polymer \\
\hline GHG & Greenhouse Gas \\
\hline GIS & Geographic Information System \\
\hline
\end{tabular}




\begin{tabular}{|c|c|}
\hline$\underline{\text { Term }}$ & Definition \\
\hline GPR & Ground-Penetrating Radar \\
\hline GrIT & Greenland Inland Traverse \\
\hline HAER & Historic American Engineering Record \\
\hline $\mathrm{HCB}$ & Hybrid-Composite Beam \\
\hline HDS & Heat-Distribution System \\
\hline HEC & Humphreys Engineer Center \\
\hline HEC-RAS & Hydrologic Engineering Centers River Analysis System \\
\hline HF & Harmonic Fold \\
\hline HgSM & Mercury Simulation Module \\
\hline HISA & Human-Infrastructure System Assessment \\
\hline HTF & Heat-Transfer Fluid \\
\hline HVAC & Heating, Ventilating, and Air-Conditioning \\
\hline IAAAP & lowa Army Ammunition Plant \\
\hline ISM & Incremental Sampling Methodology \\
\hline JBLE-E & Joint Base Langley-Eustis (JBLE-E) \\
\hline JFTC & Joint Forces Training Center \\
\hline JOA & Joint Area of Operations \\
\hline$J P-8$ & "Jet propellant 8," a kerosene-based fuel \\
\hline LID & Low Impact Development \\
\hline LiDAR & Light Detection and Ranging \\
\hline LWIR & Long-Wave Infrared \\
\hline MICC & Microbially Induced Concrete Corrosion \\
\hline MILCON & Military Construction \\
\hline MIS & McMurdo Ice Shelf \\
\hline MJH & Matthew Jones House \\
\hline MOA & Memorandum of Agreement \\
\hline MOU & Memorandum of Understanding \\
\hline MP & Miscellaneous Publication \\
\hline MPCM & Microencapsulated Phase-Change Material \\
\hline MSW & Municipal Solid Waste \\
\hline NARL & Naval Arctic Research Laboratory \\
\hline NCPTT & National Center for Preservation Technology and Training \\
\hline NEXION & Next Generation lonosonde \\
\hline NHARNG & New Hampshire Army National Guard \\
\hline
\end{tabular}




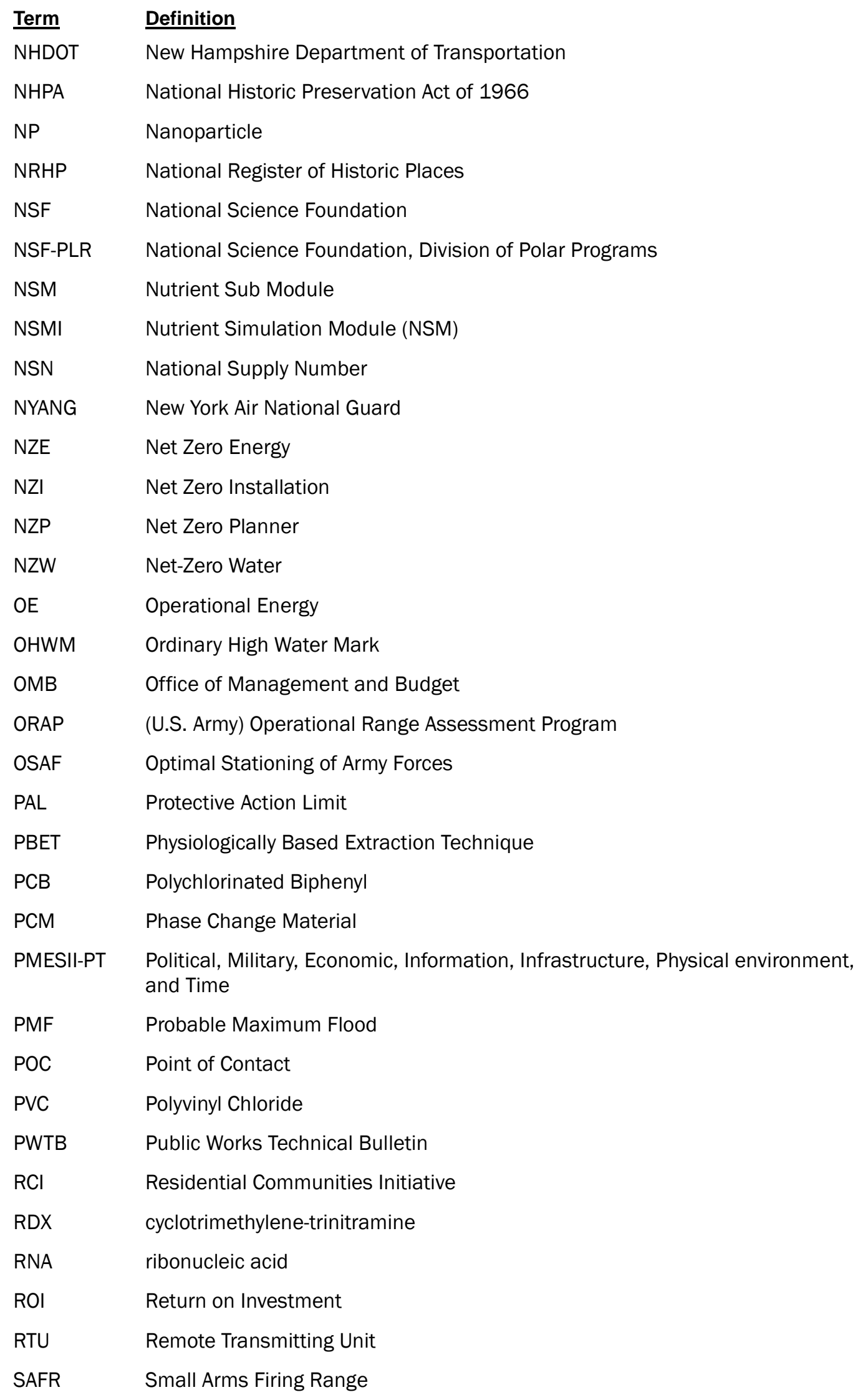




\begin{tabular}{|c|c|}
\hline$\underline{\text { Term }}$ & Definition \\
\hline SAR & Species at Risk \\
\hline SCA & Snow Covered Area \\
\hline SCADA & Supervisory Control And Data Acquisition \\
\hline SDD & Sustainable Design and Development \\
\hline SEEDS & Smart Energy Efficient Deployable Shelters \\
\hline SEM & Scanning Electron Microscope \\
\hline SERDP & Strategic Environmental Research and Development Program \\
\hline SF & Standard Form \\
\hline SMART & Sustainable, Mobile, Alternative and Renewable Technologies \\
\hline SMP & Sustain the Mission Project \\
\hline SOP & Scientific Operating Procedure \\
\hline SPLP & Synthetic Precipitation Leaching Procedure \\
\hline SR & Special Report \\
\hline SWE & Snow Water Equivalent \\
\hline TCLP & Toxicity Characteristic Leaching Procedure \\
\hline TEAM & The Environmental Assessment Management \\
\hline TES & Threatened and Endangered Species \\
\hline TGA & Thermogravimetric Analysis \\
\hline TN & Technical Note \\
\hline TR & Technical Report \\
\hline TREECS & Training Range Environmental Evaluation and Characterization System \\
\hline TSS & Topographic Support System \\
\hline UK & United Kingdom \\
\hline USACE & U.S. Army Corps of Engineers \\
\hline USAP & United States Antarctic Program \\
\hline USEPA & US Environmental Protection Agency \\
\hline USFWS & U.S. Fish and Wildlife Service \\
\hline USGBC & US Green Building Council \\
\hline VESCA & Violent Events Sociocultural Analysis \\
\hline VIIRS & Visible Infrared Imaging Radiometer Suite \\
\hline WASP & WAter Stress Projection \\
\hline WCM & Water Conservation Measure \\
\hline XPS & Extruded Polystyrene \\
\hline
\end{tabular}




\title{
Included Documents
}

\author{
Focus Area / Document $\quad$ Page
}

\section{Anticipating Emerging Issues}

Material Life Cycle Analysis for the Reduction of Waste Generation at Military Installations Identification of Insect-Plant Pollination Networks for a Midwest Installation: Fort McCoy, WI Clustered Regularly Interspaced Short Palindromic Repeat/CRISPR-associated protein 9 (CRISPR/Cas9)-based Gene Drives for Invasive Species Management on Military Lands

Extreme Environment Basing: Contingency Basing in Dense Urban and Megacity Environments

Assessment of Small Arms Munitions Impacts on Natural Infrastructure in Sensitive Downrange Areas on Military Installations

Energy and Resource Recovery from Wastewater Treatment: State of the Art and Potential Application for the Army and the DoD

\section{Climate-Driven Risks to Natural and Built Environments}

Effects of Climate Change and Urban Development on Army Training Capabilities: Firing Ranges and Maneuver Areas

Effects of Climate Change, Urban Development, and Threatened and Endangered Species Management on Army Training Capabilities: Firing Ranges

Water Stress Projection Modeling

Integrated Climate Assessment for Army Enterprise Planning

Use of Heat- and Fire-Risk Indices to Project Local Climate Impacts on Selected Army Installations

Effects of Climate Change and Urban Development on Army Training Capabilities: Firing Ranges and Maneuver Areas

Effects of Climate Change, Urban Development, and Threatened and Endangered Species Management on Army Training Capabilities

Multivariate Bioclimatic Ecosytem Change Approaches

Indicators of Physical and Biological Trends around the McMurdo Station: A Literature Review

Black-Swan Event Assessment for Fort Leonard Wood, Missouri

Developing Baselines for Prescribed Burning Smoke Management Plans and Best Management Practices

Fort Leonard Wood Net Zero Water Program: Project Documentation for Fiscal Year 2015

\section{Sustainable Installations - Net-Zero Planning}

Demonstration of The Energy Component of The Installation Master Plan Using The Net Zero Planner

Demonstrate Energy Component of The Installation Master Plan Using Net Zero Energy Installation Virtual Testbed

Considerations for Net-Zero Waste Installations

\section{Sustainable Energy Solutions}

Demonstration of a Robust Sensor System for Remote Condition Monitoring of HeatDistribution System Manholes: Final report on Project F09-AR03

Characterization of the Lake Erie Ice Cover

Economic Analysis of the Greenland Inland Traverse (GrIT)

Using Thermal Bridging Factors in Energy Models

Simulated Aging and Characterization of Phase Change Materials for Thermal Management of Building Envelopes

Kinetic Super-Resolution Long-Wave Infrared (LWIR) Thermography Diagnostic for Building Envelopes

Kinetic Super-Resolution Long-Wave Infrared (LWIR) Thermography Diagnostic for Building Envelopes: Scott AFB, IL

Kinetic Super-Resolution Long-Wave Infrared (LWIR) Thermography Diagnostic for Building Envelopes: Camp Lejeune, NC

Prediction of Long Term Degradation of Insulating Materials

Level I Energy and Water Survey, ERDC-CERL, Champaign, IL

Field Validation of Microencapsulated Phase-Change Material Slurries as Heat-Transfer Fluids

Energy and Resource Recovery from Wastewater Treatment: State of the Art and Potential Application for the Army and the $D o D$

NHARNG Wind Resource Assessment: Center Strafford Training Center 


\section{Focus Area / Document Page}

\section{Sustainable Water \& Waste Resources}

Organic Waste Diversion Guidance for U.S. Army Installations

Demonstration of Combined Food and Landscape Waste Composting at Fort Leonard Wood, MO: Fort Leonard Wood Installation Strategic Sustainable Plan

Identifying Areas of Potential Wetland Hydrology in Irrigated Croplands Using Aerial Image Interpretation and Analysis of Rainfall Normality

Energy and Resource Recovery from Wastewater Treatment: State of the Art and Potential Application for the Army and the DoD

\section{Sustainable Facilities and Infrastructure}

Effect of Arctic Amplification on Design Snow Loads in Alaska: SERDP RC-2435 36

Assessment of Asphalt Concrete Reinforcement Grid in Flexible Pavements

Summit Station Skiway Cost Analysis

Ground-Penetrating-Radar Profiles of Interior Alaska Highways: Interpretation of Stratified Fill, Frost Depths, Water Table, and Thaw Settlement over Ice-Rich Permafrost

Matthew Jones House: Recommendations for Treatment

Landscape Evolution of the Oil Spill Mitigation Sand Berm in the Chandeleur Islands, Louisiana

Field Testing and Summary Report for Road 5 (Morris Road) over Road 3 (Toftoy Throughway) at Redstone Arsenal, AL: Contractor's Supplemental Report for Project F09-AR16

Field Testing and Load Rating Report for Bridge No. 4, Composite Grid Reinforcement of Concrete Deck, at Fort Knox, Kentucky: Contractor's Supplemental Report for Project F12-AR01

Field Testing and Load Rating Report for Bridge No. 4, Hybrid Composite Beam Span, at Fort Knox, Kentucky: Contractor's Supplemental Report for Project F12-AR15

Historic American Engineering Record (HAER) Level II Documentation of Launch Complexes 1/2, 3/4, 9/10, 14, and 34 at Cape Canaveral Air Force Station, Florida

Cultural Landscape Analysis of Existing Historic Districts: Picatinny Arsenal, New Jersey

Demonstration of A Liquid-Applied Liner System for Corrosion Protection and Rehabilitation of Wastewater System Structures: Final Report on Project F11-AR24

Character-Defining Features of Contributing Buildings and Structures in the Signal School Campus Historic District at Fort Gordon, Georgia

Corrosion Control of Central Vehicle Wash Facility Pump Components Using Alternative Alloy Coatings: Final Report on Project F09-AR14

Architectural Survey of Laramie Armory, Wyoming Army National Guard

NRHP Eligibility of the Fort Huachuca, Arizona, Elevated Water Tank (Facility 49001) and reservoir (Facility 22020)

Assessing Socioeconomic Impacts of Cascading Infrastructure Disruptions Using the Capability Approach

Cultural Landscape Inventory for Picatinny Arsenal, New Jersey

Demonstration and Validation of a Composite Grid Reinforcement System for Bridge Decks: Final report on Project F12-AR01

Demonstration of Corrosion-Resistant Hybrid Composite Bridge Beams for Structural Applications: Final Report on Project F12-AR15

Modeling the Fate of Lead from Small Arms Firing Ranges, Fort Jackson, SC

The Department of Homeland Security Supplement to the Environmental Assessment and Management (TEAM) Guide

Understanding the Effects of Infrastructure Changes on Subpopulations: Survey of Current Methods, Models, and Tools

Update of Opportunities for Reducing Construction and Demolition Waste from Residential Communities Initiative (RCl) Programs

Multinational Analysis of Military Vehicle Impacts and Regulatory Pressures on Training Land Management

Creative Strategies and Opportunities for Managing Cultural Resources on Army Training Lands

[F09-AR02] Demonstration and Validation of Materials for Corrosion-Resistant Fencing and Guard Railings in Aggressive Climates

Terrain and The Physical Environment: Factors for Noise Mitigation

Multifunctional Nanocomposites for Improved Sustainability and Protection of Facilities

[F10-AR01] Corrosion-Resistant Coatings for Air-Conditioning Coils and Fans

Inventory and Evaluation of Buildings in the Industrial Area, Cape Canaveral Air Force Station

The Army and the FHWA Program Comment for Common, Post-1945 Concrete and Steel Bridges

Architectural Survey of Ohio Army National Guard Properties: Volume I - Main Report Camp Sherman, Ohio: History of a World War I Training Camp

Cultural Landscape Analysis of Existing Historic Districts: Picatinny Arsenal, New Jersey 
Focus Area / Document $\quad$ Page

Architectural Survey at Joint Base Langley-Eustis of Fort Eustis Buildings and Structures Built 1946-1975: Volume I

Site Assessment and Feasibility of a New Operations Base on the Greenland Ice Sheet: Addendum to the Preliminary Report

Analysis of Operational Data: A Proof-of Concept for Assessment of Electrical Infrastructure Impact

Evaluation of Environmentally Acceptable Lubricants (EALs) for Dams Managed by the U.S. Army Corps of Engineers

Geotechnical Study, Next Generation Ionosonde (NEXION) Installation, Thule Air Base, Greenland

Vertical Temperature Simulation of Pegasus Runway, McMurdo Station, Antarctica

Remediation of Old South Pole Station: Phase I: Ground-Penetrating-Radar Surveys

Remediation of Old South Pole Station Using Autonomous Data Collection and Remote Assessment of Ground-Penetrating Radar

Review of the Probable Maximum Flood (PMF) Snowmelt Analysis for Success Dam

Structural Condition Assessment of Reinforced Base Course Pavement

\section{Sustainable Contingency Basing}

Opportunities for Waste Heat Recovery at Contingency Bases

Assessing Socioeconomic Impacts of Cascading Infrastructure Disruptions in a Dynamic Human-Infrastructure Network

SMART Energy Efficient Deployable Shelters (SEEDS)

Novel Anaerobic Wastewater Treatment System for Energy Generation at Forward Operating Bases: Final Report on Environmental Restoration Project ER-2218

Construction Material-Based Methodology for Military Contingency Base Construction: Case Study of Dhaka, Bangladesh

Machine Classification of Text and the Detection of Dominant Political Narratives

Mold Remediation and Recommendations to Resolve Other Major Issues in Concrete B-Huts at Bagram Airfield, Afghanistan

\section{Sustainable Natural Infrastructure}

Evaluation of Electromagnetic Induction (EMI) Resistivity Technologies for Assessing Permafrost Geomorphologies

A Species Distribution Modeling Informed Conservation Assessment of Bog Spicebush

Synthesizing the Scientific Foundation for Ordinary High Water Mark Delineation in Fluvial Systems

Autonomous Sea-Ice Thickness Survey

Technology Transfer of Biopolymer Soil Amendment for Rapid Revegetation and Erosion Control at Fort A. P. Hill, Virginia

Image Analysis and Classification Based on Soil Strength

Adaptation Strategies for Training Lands and Ranges at Fort Leonard Wood, MO

Nanomaterial Dispersion/Dissolution Characterization: Scientific Operating Procedure SOP$F-1$

California Least Tern Foraging Ecology in Southern California: A Review of Foraging Behavior Relative to Proposed Dredging Locations

Evaluation of 757 Species under U.S. Endangered Species Act Review on U.S. Department of Defense Lands and their Potential Impact on Army Training

Evaluation of Suitable Population and Habitat Suitability Models for Endangered Avian Species Populations on Fort Hood, TX

Imaging of Ground Ice with Surface-Based Geophysics

Assessment of Small Arms Munitions Impacts on Natural Infrastructure in Sensitive Downrange Areas on Military Installations

\section{Green Remediation and Reuse}

Composition of CBRN Decontamination Effluent and Development of Surrogate Mixtures for Testing Effluent Treatment Technologies

Removing Hazardous Materials from Buildings: A Training Curriculum

Testing and Validation Studies of the NSMII-Benthic Sediment Diagenesis Module

Aquatic Contaminant and Mercury Simulation Modules Developed for Hydrologic and Hydraulic Models

Evaluation of Rhizobium tropici-derived Biopolymer for Erosion Control of Protective Berms. Field Study: lowa Army Ammunition Plant

Flexible Reactive Berm (FRBerm) for Removal of Heavy Metals from Runoff Water: ER-1213 Treatability Study

Impact of Incremental Sampling Methodology (ISM) on Metals Bioavailability 
Focus Area / Document

Page

Complete Host Range Testing on Common Reed with Potential Biological Control Agents and Investigation into Biological Control for Flowering Rush

91

Side Channels of the Impounded and Middle Mississippi River: Opportunities and Challenges to Maximize Restoration Potential

CONUS Demonstration Site Selection for Surface Water Characterization in Remote, SparseData Environments: Calleguas Creek Watershed, Ventura County, California

Testing of the KRIA lonizing Water Treatment System for Waters Contaminated with Diesel, PCBs, and Nutrients (Nitrogen Forms)

The Biodiversity Security Index: A New Metric for Benefits from USACE Ecosystem Restoration Projects

Laboratory-Scale Demonstration Using Dilute Ammonia Gas Induction of Alkaline Hydrolysis Treatment of Soil Chlorinated Propanes and Explosives

Soil Temperature and Moisture Effects on Soil Respiration and Microbial Community Abundance

Naval Arctic Research Laboratory (NARL) Subsurface Containment Berm Investigation

Update of Opportunities for Reducing Construction and Demolition Waste from Residential Communities Initiative (RCl) Programs 


\section{REPORT DOCUMENTATION PAGE}

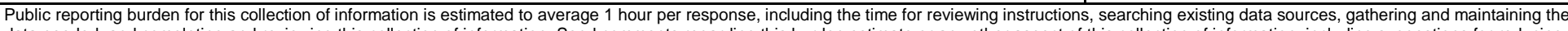

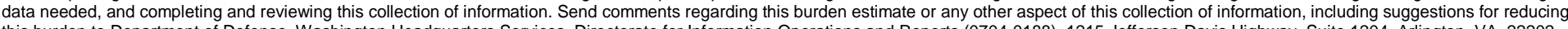

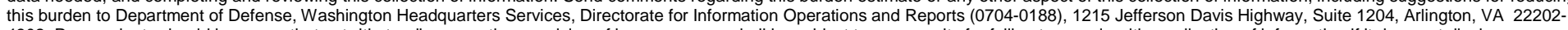

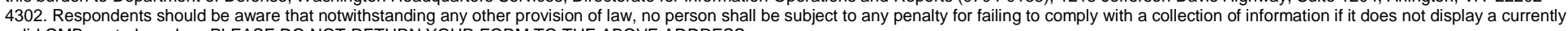
valid OMB control number. PLEASE DO NOT RETURN YOUR FORM TO THE ABOVE ADDRESS.
1. REPORT DATE (DD-MM-YYYY)
06/09/2017
2. REPORT TYPE
Final

\section{TITLE AND SUBTITLE}
3. DATES COVERED (From - To)
5a. CONTRACT NUMBER

Sustainability-Related Publications Calendar Years 2015 - 2016

Franklin H. Holcomb, Patrick N. Deliman, and David B. Ringelberg

5b. GRANT NUMBER

5c. PROGRAM ELEMENT

5d. PROJECT NUMBER

5e. TASK NUMBER

5f. WORK UNIT NUMBER

8. PERFORMING ORGANIZATION REPORT NUMBER

ERDC SR-17-2

U.S. Army Engineer Research and Development Center (ERDC)

Construction Engineering Research Laboratory (CERL)

PO Box 9005,

Champaign, IL 61826-9005

\section{SPONSORING / MONITORING AGENCY NAME(S) AND ADDRESS(ES)}

U.S. Army Engineer Research and Development Center (ERDC)

Construction Engineering Research Laboratory (CERL)

2902 Newmark Dr.

Champaign, IL 61824
10. SPONSOR/MONITOR'S ACRONYM(S)

CEERD-CZT

11. SPONSOR/MONITOR'S REPORT NUMBER(S)

\section{DISTRIBUTION I AVAILABILITY STATEMENT}

Approved for public release; distribution is unlimited.

\section{SUPPLEMENTARY NOTES}

\section{ABSTRACT}

The Center for the Advancement of Sustainability Innovations (CASI) was established by the U.S. Army Engineer Research and Development Center (ERDC) as a new capability in 2006 hosted at the Construction Engineering Research Laboratory (CERL) in Champaign, IL. CASI was established with the goal of focusing the value of ERDC expertise, technologies, and partnerships toward helping the U.S. Army Corps of Engineers (USACE), the Army, and the Department of Defense (DoD) achieve more sustainable facilities and operations. CASI provides the military with capabilities that enhance national security by more effectively using limited resources and improving coordination and partnerships with host communities and stakeholders in the United States and around the globe. CASI teams strive to measure sustainability innovations against the Triple Bottom Line of mission, environment, and community. CASI focuses on cost savings, innovation, collaborative solutions, and continuous learning — which directly link sustainability to Army policy and guidance documents including Army Installations 2025; Installations, Energy and Environment Strategy 2025; Army Environment, Safety, \& Occupational Health Strategy 2025; and Energy Security and Sustainability (ES2) Strategy. Note that this "summary of sustainability-related publications" incorporates descriptions of work related to the theme of sustainability conducted under many ERDC programs as well as CASI.

\section{SUBJECT TERMS}

CASI, Center for the Advancement of Sustainability Innovations, Army, environment, sustainability

\begin{tabular}{|c|c|c|c|c|c|}
\hline \multicolumn{3}{|c|}{ 16. SECURITY CLASSIFICATION OF: } & \multirow{2}{*}{$\begin{array}{l}\text { 17. LIMITATION } \\
\text { OF ABSTRACT } \\
\text { SAR }\end{array}$} & \multirow{2}{*}{$\begin{array}{l}\text { 18. NUMBER } \\
\text { OF PAGES } \\
113\end{array}$} & 19a. NAME OF RESPONSIBLE PERSON \\
\hline $\begin{array}{l}\text { a. REPORT } \\
\text { Unclassified }\end{array}$ & $\begin{array}{l}\text { b. ABSTRACT } \\
\text { Unclassified }\end{array}$ & $\begin{array}{l}\text { c. THIS PAGE } \\
\text { Unclassified }\end{array}$ & & & $\begin{array}{l}\text { 19b. TELEPHONE NUMBER } \\
\text { (include area code) }\end{array}$ \\
\hline
\end{tabular}

